IZA DP No. 9606

Do Higher Corporate Taxes Reduce Wages?

Clemens Fuest Andreas Peichl Sebastian Siegloch

December 2015 


\title{
Do Higher Corporate Taxes Reduce Wages?
}

\author{
Clemens Fuest \\ ZEW, University of Mannheim, CESifo and IZA \\ Andreas Peichl \\ ZEW, University of Mannheim, IZA and CESifo \\ Sebastian Siegloch \\ University of Mannheim, IZA, ZEW and CESifo
}

\section{Discussion Paper No. 9606 \\ December 2015}

\author{
IZA \\ P.O. Box 7240 \\ 53072 Bonn \\ Germany \\ Phone: +49-228-3894-0 \\ Fax: +49-228-3894-180 \\ E-mail: iza@iza.org
}

\begin{abstract}
Any opinions expressed here are those of the author(s) and not those of IZA. Research published in this series may include views on policy, but the institute itself takes no institutional policy positions. The IZA research network is committed to the IZA Guiding Principles of Research Integrity.

The Institute for the Study of Labor (IZA) in Bonn is a local and virtual international research center and a place of communication between science, politics and business. IZA is an independent nonprofit organization supported by Deutsche Post Foundation. The center is associated with the University of Bonn and offers a stimulating research environment through its international network, workshops and conferences, data service, project support, research visits and doctoral program. IZA engages in (i) original and internationally competitive research in all fields of labor economics, (ii) development of policy concepts, and (iii) dissemination of research results and concepts to the interested public.
\end{abstract}

IZA Discussion Papers often represent preliminary work and are circulated to encourage discussion. Citation of such a paper should account for its provisional character. A revised version may be available directly from the author. 
IZA Discussion Paper No. 9606

December 2015

\section{ABSTRACT}

\section{Do Higher Corporate Taxes Reduce Wages?*}

This paper estimates the incidence of corporate taxes on wages using a 20-year panel of German municipalities. Administrative linked employer-employee data allows estimating heterogeneous worker and firm effects. We set up a general theoretical framework showing that corporate taxes can have a negative effect on wages in various labor market models. Using an event study design, we test the predictions of the theory. Our results indicate that workers bear about $40 \%$ of the total tax burden. Empirically, we confirm the importance of both labor market institutions and profit shifting possibilities for the incidence of corporate taxes on wages.

JEL Classification: $\quad \mathrm{H} 2, \mathrm{H} 7, \mathrm{~J} 3$

Keywords: business tax, wage incidence, administrative data, local taxation

Corresponding author:

Andreas Peichl

Centre for European Economic Research (ZEW)

$\mathrm{L} 7,1$

68161 Mannheim

Germany

E-mail: peichl@zew.de

\footnotetext{
* We would like to thank Hilary Hoynes, the editor, and three anonymous referees for their helpful comments. We are indebted to W. Arulampalam, A. Auerbach, R. Blundell, D. Card, R. Chetty, M. Devereux, P. Doerrenberg, D. Duncan, G. Friebel, J. Hines, H. Kleven, G. Maffini, A. Oswald, M. Overesch, T. Piketty, E. Saez, J.C. Suarez Serrato, J. Voget, D. Yagan, O. Zidar, as well as numerous conference and seminar participants for valuable comments and suggestions on earlier versions (sometimes circulating as "Do Employees Bear the Burden of Corporate Taxation? A Micro Level Approach Using Linked Employer-Employee Data").
} 


\section{Introduction}

Most economists think that labor bears part of the burden of corporate taxation. ${ }^{1}$ However, there is considerable disagreement on how much of the corporate tax burden is shifted onto workers. The theoretical literature, inspired by Harberger (1962)'s seminal contribution, predicts that the incidence on wages depends on the assumptions regarding the openness of the economy (Diamond and Mirrlees, 1971; Bradford, 1978; Kotlikoff and Summers, 1987; Harberger, 1995), its sectoral composition (Shoven, 1976), savings behavior (Feldstein, 1974; Bradford, 1978) and the presence of uncertainty in the economy (Ratti and Shome, 1977). ${ }^{2}$ Little attention has been paid to the role of wage setting institutions and labor market frictions. With the exception of Felix and Hines (2009) and Arulampalam et al. (2012) who study corporate taxes in a wage bargaining context, most existing studies assume a competitive labor market.

Credible empirical evidence on the incidence of corporate taxes is scarce. Sufficient and exogenous variation in corporate tax rates is essential for identifying the causal effect of higher corporate taxes. Cross-country research designs (such as Hassett and Mathur, 2006; Felix, 2007; Desai et al., 2007) must defend their (implicit or explicit) common trend assumptions. Single-country designs can establish a valid control group more easily. Most existing studies (such as Dwenger et al., 2011; Arulampalam et al., 2012; Liu and Altshuler, 2013), however, have to rely on variation in the tax burden that is not driven solely by policy reforms but also by firm choices. For instance, differences in tax burdens across industries or due to formula apportionment may depend directly on sales and investment activities which might be endogenous to tax rates as well. In a recent contribution, Suárez Serrato and Zidar (2014) calibrate a spatial equilibrium model based on reduced-form estimates exploiting changes in tax rate differentials and variation from formula apportionment weights across the 52 U.S. federal states. ${ }^{3}$

In this paper, we revisit the question of the incidence of corporate taxes on wages both theoretically and empirically. First, we develop a theoretical model that explicitly accounts for the role of wage setting institutions and labor market frictions for the incidence of corporate taxation. Second, we exploit the specific institutional setting of the German local business tax $(\mathrm{LBT})^{4}$ to identify the corporate tax incidence on wages.

\footnotetext{
${ }^{1}$ For example, public economists surveyed by Fuchs et al. (1998) respond on average that $40 \%$ of the corporate tax incidence is on capital (with an interquartile range of 20-65\%) leaving a substantial share of the burden for labor (and land owners or consumers).

2 Surveys of the literature are provided by Auerbach (2005) and Harberger (2006). Computational general equilibrium (CGE) models find that labor bears a substantial share of the corporate tax burden under reasonable assumptions (see Gravelle, 2013, for an overview).

${ }^{3}$ Felix and Hines (2009) also use U.S. state variation but rely on cross-sectional data.

${ }^{4}$ See, e.g., Büttner (2003); Janeba and Osterloh (2012); Foremny and Riedel (2014) for studies ana-
} 
In the first part of the paper, we set up a general theoretical framework that allows us to derive testable predictions for the effect of corporate tax changes on wages under different assumptions regarding wage setting institutions and labor market frictions. In most settings, higher corporate taxes reduce wages, albeit for different reasons. This holds true in particular for models with individual and collective wage bargaining, fair wage models, models where higher wages allow firms to hire more productive workers and monopsonistic labor markets. However, the wage effects are diluted and may disappear completely if collective bargaining takes place at the sector-level (compared with the firmlevel), if there is formula apportionment for firms operating in multiple jurisdictions or if firms react to higher corporate taxes by shifting income to the personal income tax base or to other countries.

In the second part, we test the theoretical predictions using administrative panel data on German municipalities from 1993 to 2012. Germany is well suited to test our theoretical model for several reasons. First, we have substantial tax variation at the local level. From 1993 to 2012, on average 12.4\% of municipalities adjusted their LBT rates per year. Eventually, we exploit 17,999 tax changes in 10,001 municipalities between 1993 to 2012 for identification. ${ }^{5}$ Compared to cross-country studies, the necessary common trend assumption is more likely to hold in our setting since municipalities are more comparable than countries. Second, municipalities can only change the LBT rate, while the tax base definition and liability conditions are determined at the federal level. ${ }^{6}$ Hence, the variation in tax rates we exploit empirically does not depend on (current) firm choices. Moreover, the municipal autonomy in setting tax rates allows us to treat municipalities as many small open economies within the highly integrated German national economy - with substantial mobility of capital, labor and goods across municipal borders. General equilibrium effects on interest rates or consumer prices are therefore likely to be of minor importance in this setting. This is likely to be true even for sectors producing non-tradeable goods like the service sector since individuals may buy these services in the neighboring municipality. Third, the German labor market is characterized by a variety of wage setting institutions which include sector and firm-level collective bargaining as well as wage setting on the basis of contracts between firms and individual employees. In order to shed light on the specific interactions of labor market institutions and tax changes, we match the municipal

lyzing the LBT.

${ }^{5}$ Bauer et al. (2012) also investigate the LBT. However, as in an earlier version of this paper (Fuest et al., 2011), they average tax rates on the county level (consisting of 28 municipalities on average). Due to this aggregation, firms in unaffected municipalities are wrongly exposed to a change in the county's average tax rate leading to biased results. Moreover, Bauer et al. (2012) lack relevant firm data because they do not use linked employer-employee data.

${ }^{6}$ Kawano and Slemrod (2012) compare a large number of reforms of nationwide corporate taxes and show that tax rate change are usually combined with changes in the tax base as well. 
data to administrative linked employer-employee micro data that combine social security records with a representative firm survey.

We apply an event study design to estimate the effect of corporate tax changes on wages and test the predictions of our theoretical model. ${ }^{7}$ We find a negative overall effect of higher corporate taxes on wages. For a 1-euro increase in the tax bill, the wage bill decreases by 56 cents. $^{8}$ Assuming a marginal excess burden of the corporate tax of $29 \%$ (Devereux et al., 2014), about $43 \%$ of the incidence of the local business tax is borne by workers. Our findings are robust to the inclusion of a comprehensive set of very local and flexible controls (including "commuting-zone $\times$ year" fixed effects) suggesting that omitted variables such as local shocks are not driving our results. Moreover, we find no effects for firms that are exempt from the LBT.

In the next step, we test for heterogeneous tax effects on the firm and worker level. We find more pronounced negative effects in firms with firm-level compared to sector-level bargaining agreements. For firms that are not covered by bargaining agreements, we also find negative wage effects. Among firms not covered by the bargaining agreements, firms that take sectoral collective bargaining agreements as a reference point show stronger responses. One interpretation of this finding is that fair wage considerations may play a role in these cases. Looking at single-plant versus multi-plant firms, we find negative wage effects only for the former, which is in line with the theoretical prediction that wage effects will be smaller in multi-establishment firms because they are subject to formula apportionment and may be able to shift profits regionally or internationally. In terms of worker heterogeneity, we find that female workers are affected more strongly. This finding could be rationalized with a monopsonistic labor market model and relatively more elastic labor supply for these groups.

We contribute to the literature in several ways. First, we provide new estimates for the corporate tax incidence on wages exploiting the German institutional setting, which gives rise to substantial variation in tax rates. Second, going beyond the German case, our general theoretical analysis highlights the role of labor market institutions for tax incidence, which has not received much attention so far. The relevance of the different types of labor market frictions that we consider differs across countries. While unions are strong in some countries, others exhibit more competitive labor markets where individual wage bargaining might be more relevant, as assumed in search and matching models. ${ }^{9}$ In

\footnotetext{
7 The event study design also allows to check for reverse causality. These checks do not suggest that reverse causality drives our results.

8 Note that only very few nominal wage decreases are observable in the data. Our wage responses are rather driven by lower nominal wage increases leading to lower nominal wage levels in the future in the treated municipalities.

${ }^{9}$ Unions are especially important in Northern and Continental European countries, as well as Aus-
} 
addition, fair wage considerations or firms that set higher wages to hire more productive workers are also likely to be relevant in many countries. Third, our detailed linkedemployer employee data allows us to investigate heterogeneous firm and worker effects and test many of our theoretical predictions. For instance, we observe firms with and without collective bargaining agreements, which allows us to empirically test the role of different labor market frictions predicted by the theory. Furthermore, we find differences in tax incidence between small versus large firms and profitable versus less profitable firms, which are likely to be important in other countries as well. Last, we study corporate taxation at the subnational level which is important in many countries. ${ }^{10}$ Compared to changes in state or national corporate tax rates, two potential differences are worth noting. On the one hand, relative mobility of labor might be lower at a more aggregated level, which should lead to larger wage effects of tax changes. On the other hand, price effects are likely to be more important when looking at state or national tax changes, which should decrease the incidence on labor.

The rest of the paper is structured as follows. In Section 2, we discuss the incidence of corporate taxes on wages in a broad theoretical framework, paying special attention to the interaction of labor market institutions and corporate taxation. In Section 3, we briefly describe the German institutional setting, in particular the corporate tax system focusing on the LBT, whose variation we exploit in the empirical part of the paper. The empirical model is set up in Section 4.1. Section 4.2 presents the administrative linked employer-employee dataset used for the analysis. Empirical results are shown and discussed in Section 5. Section 6 presents our conclusions.

\section{The theory of corporate tax incidence}

The theoretical literature has produced a variety of models on corporate tax incidence. These models lead to different predictions, depending on the assumptions made about factor and output markets, wage setting institutions, the structure of the tax system and behavioral reactions to tax changes. In the seminal paper by Harberger (1962), the economy is closed, labor markets are competitive and capital is in fixed supply. ${ }^{11}$ The corporate tax is a tax per unit of capital, which distorts investment between the incorporated and the unincorporated sector. At least for plausible parameter values, the

tralia, Canada, New Zealand and Mexico - see the OECD Trade Union Density statistics: http: //stats. oecd.org/Index . aspx?DataSetCode=UN_DEN.

${ }^{10}$ For OECD countries, prominent examples include the U.S., Canada, France, Italy, Japan, Spain and Switzerland (see, e.g., Bird, 2003; Spengel et al., 2014, for overviews).

${ }^{11}$ Feldstein (1974) and Ballentine (1978) study the tax incidence in models with endogenous savings and find that part of the tax burden is shifted to labor. 
tax burden is almost fully borne by capital.

While the closed economy assumption is a key feature of the Harberger model, the more recent literature has emphasized international capital mobility (see e.g. Bradford, 1978; Kotlikoff and Summers, 1987; Harberger, 2006). In open economies, the share of the corporate tax burden borne by domestic immobile factors increases as the economy relative to the rest of the world decreases. ${ }^{12}$ In the case of a small open economy that faces a perfectly elastic supply of capital, the burden of the corporate tax is fully borne by factors other than capital. ${ }^{13}$ If profits of a firm are the result of location specific rents, the tax will partly fall on these rents. By contrast, if rents are firm specific and firms are mobile, the tax burden will be fully shifted to owners of immobile factors like land or labor (see Kotlikoff and Summers, 1987, section 3). ${ }^{14}$

In a setting with local corporate taxes and with both labor and capital mobility across jurisdictions, a decline in wages in response to higher taxes would induce workers to seek employment in other jurisdictions. In the case of perfect labor mobility and competitive labor markets, the wage rates would be determined in the national labor market and individual local corporate tax changes would not affect the wage rate. Assuming that output prices are little affected by changes in local tax rates, higher local corporate taxes would fall on land or reduce other location-specific rents.

The assumption that mobility makes wages completely independent of local conditions is restrictive, however, and not just because of mobility costs. One reason why this assumption may not hold is that local public services may affect migration decisions. If a corporate tax change leads to higher local public spending, workers might accept lower wages in return for better public services. Thus, higher corporate taxes may lead to lower local wages if accompanied by more public services. This would suggest that higher local taxes reduce wages even in tax exempt firms.

Another restrictive assumption is that labor markets are competitive. To understand the impact of corporate tax changes on wages it is important to take into account labor market imperfections and wage setting institutions. In the next subsections, we develop a simple theoretical framework that enables the study of corporate tax incidence in the presence of various forms of labor market imperfections.

\footnotetext{
12 This applies to a source based corporate income tax. Residence based taxes may have more complicated incidence effects. Most existing corporate taxes are, in effect, source based taxes.

${ }^{13}$ From a global perspective, a tax increase in one jurisdiction reduces the income of immobile labor in that jurisdiction but increases labor income and reduces capital income in the rest of the world. This point was first made by Bradford (1978), with respect to prices of immobile property.

${ }^{14}$ In principle, the tax burden may also fall on suppliers or on customers, provided input and output prices are not pinned down by international markets.
} 


\subsection{A model of corporate tax incidence with labor market im- perfections}

Labor market theory has produced many ideas and views about how wages and employment are determined. In the following, we discuss the implications of various labor market models for corporate tax incidence. As a benchmark, we start with the case of competitive labor markets. We then turn to models with wage bargaining, fair wage models, models where wages affect worker productivity and monopsonistic labor markets. ${ }^{15}$

Assume that profits of firm $i$, located in jurisdiction $j$, are given by

$$
P_{i j}=p_{i} F_{i}\left(K_{i}, L_{i}^{h}, L_{i}^{l}\right)\left(1-\tau_{j}\right)-\sum_{k} w_{i}^{k} L_{i}^{k}\left(1-\phi \tau_{j}\right)-\left(1-\alpha \tau_{j}\right) r_{i} K_{i}
$$

where $p_{i}$ is the output price, $F_{i}$ is a production function with the usual properties, $K_{i}$ is capital, $r_{i}$ is the non-tax cost of capital, $L_{i}^{k}$ is labor of skill type $k$ and $w_{i}^{k}$ is the corresponding wage. We assume that there are two skill types, $k=h, l .{ }^{16}$ The tax rate on corporate profits in jurisdiction $j$ is denoted by $\tau_{j}$. Parameters $\phi$ and $\alpha$ describe the tax deductibiliy of labor and capital costs, respectively. A cash flow tax with perfect loss offset would imply $\phi=\alpha=1$, that is, the full deductibility of all costs. Existing corporate tax systems are more restrictive, however. First, costs of debt financing are usually deductible while costs of equity financing are not. Second, loss offset is usually restricted, which implies that all costs including labor costs are effectively less than fully deductible. These properties of the corporate tax base are important for theoretical predictions about the incidence, as will be shown further below. In the following we normalize the number of firms per jurisdiction to unity and drop the index $j$ for firm variables to ease notation. Total differentiation of the profit equation and using the standard first order conditions for profit maximization yields

$$
\begin{aligned}
d P_{i}= & -d \tau_{j} T_{i}+d p_{i} F_{i}\left(K_{i}, L_{i}^{h}, L_{i}^{l}\right)\left(1-\tau_{j}\right)-\sum_{k} d w_{i}^{k} L_{i}^{k}\left(1-\phi \tau_{j}\right) \\
& -d r_{i}\left(1-\alpha \tau_{j}\right) K_{i}
\end{aligned}
$$

where

$$
T_{i}=p_{i} F_{i}\left(K_{i}, L_{i}^{h}, L_{i}^{l}\right)-\phi \sum_{k} w_{i}^{k} L_{i}^{k}-\alpha r_{i} K_{i}
$$

is the profit tax base.

\footnotetext{
15 In the main text we will focus on a mostly verbal discussion of the different theories. The formal derivations are given in Appendix A.

16 To keep the notation simple we abstract from other input factors like land, energy or other intermediate goods. Clearly, the prices of these goods could also be affected by corporate tax changes and the suppliers might bear part of the corporate tax burden. Corporate tax changes could also be capitalized in house prices.
} 
Equation (1) shows that a tax increase may lead to lower profits for firm owners, higher output prices charged to customers, a decline in wages received by workers, lower income for capital owners or a combination of these effects. ${ }^{17}$ It is also possible that some of these groups lose while others gain.

The distribution of the tax burden depends on how the model is closed, that is, on the assumed overall structure of the economy, in particular the supply and demand elasticities in factor markets and the wage setting institutions. For the case of competitive labor markets, we show in Appendix A how the effect of tax changes on wages depends on the price elasticities of labor supply and demand in our model. Moreover, the corporate tax base plays a key role. To see this, consider the simplest theory of corporate tax incidence, the theory that the tax falls entirely on profits, that is $d P_{i}=-d \tau_{j} T_{i}$ (see Auerbach, 2005, for a detailed discussion of this view). This prediction emerges from our model if all costs are fully deductible $(\phi=\alpha=1)$, so that the tax is effectively a cash flow tax that is neutral for factor demand, and if all factor markets including the labor market are competitive. We summarize these two insights below:

Result 1: Competitive labor markets: The impact of a tax change on wages depends on the demand and supply elasticities in the labor market. If all costs are perfectly deductible, the burden of the corporate income tax is fully borne by firm owners. Then a tax rate change does not affect the wage rate.

The proof of this result is given in Appendix A. The second part of Result 1 simply reflects that a cash flow tax is effectively a lump sum tax on corporate profits. It is important as a benchmark for the following analysis since it highlights the importance of the tax base, a factor which is often neglected in the literature. Interestingly, the cash flow tax result also carries over to various (but not all) standard models of imperfect labor markets, as we will show below. Most real world corporate tax systems deviate from the polar case of a profit tax with perfect cost deductibility, however. Accordingly, models of tax incidence in the literature typically consider settings where either capital or labor costs are less than fully deductible.

\subsection{Corporate tax incidence with wage bargaining}

Various labor market theories assume that wages are set via bargaining between firms and their employees. Wage bargaining may occur between individual firms and individual

\footnotetext{
17 More formally, equation (1) implies $\frac{d P_{i}}{d \tau_{j}} \mid d p_{i}=d w_{i}^{k}=d r_{i}=0=-T_{i}<0$, ${\frac{d p_{i}}{d \tau_{j}} \mid d P_{i}=d w_{i}^{k}=d r_{i}=0}^{d}=\frac{T_{i}}{F_{i}\left(K_{i}, L_{i}^{h}, L_{i}^{l}\right)\left(1-\tau_{j}\right)}>0, \frac{d w_{i}^{k}}{d \tau_{j}} \mid d P_{i}=d p_{i}=d r_{i}=d w_{i}^{l}=0=-\frac{T_{i}}{L_{i}^{k}\left(1-\phi \tau_{j}\right)}<0, \forall l \neq k$, $\frac{d r_{i}}{d \tau_{j}} \mid d P_{i}=d p_{i}=d w_{i}^{k}=0=-\frac{T_{i}}{\left(1-\alpha \tau_{j}\right) K_{i}}<0$. The signs of the effects are based on the assumption of a positive tax base.
} 
employees, but it may also take the form of collective bargaining, where employees are represented by trade unions.

Bargaining models imply that firm owners and employees share a surplus generated by the firm. If corporate taxes reduce this rent, it is natural to expect that part of the loss is shared by employees through lower wages. The magnitude of these wage effects depends on the level where bargaining takes place.

\subsubsection{Individual wage bargaining}

Assume that a firm hires a worker who generates a surplus $Q$ and receives a wage $w$. The wage is set via bargaining between the firm and the employee. The most widely used labor market model where this happens is the job search model, in which firms and individual employees bargain over a matching rent (see Rogerson et al., 2005, for a survey of labor market search theories).

The available surplus after corporate taxes is given by $Q(1-\tau)+w \phi \tau$. A tax increase by $d \tau$ reduces the after-tax surplus before wage payments by $Q d \tau$ but the tax change reduces the after-tax cost of wage payments by $d \tau \phi w$. A higher corporate tax reduces the surplus the firm and the employee can share but the tax also "subsidizes" wage payments. Here standard bargaining models like the Nash bargaining model imply that each effect neutralizes the other if all costs are perfectly deductible. Existing tax systems usually restrict the deductibility of costs through loss offset limitations or by restricting capital allowances. In this case, part of the burden of a higher corporate tax is passed on to employees. The effect increases with the bargaining power of the employee. If the employee receives a large part of the surplus generated by the firm, it is plausible that she also bears a large loss if the surplus declines due to taxation.

In Appendix A, we analyze the effect of a corporate tax change in a simple model of bargaining between individual employees and firms. There we derive

Result 2: Individual wage bargaining: If wage or capital costs are less than fully deductible, an increase (decline) in the local corporate tax rate reduces (increases) the wage. The effect increases with the relative bargaining power of the employee.

\subsubsection{Collective bargaining}

Collective bargaining may take place at the firm-level, the sector-level or at the national level. Taking into account the level at which wage bargaining takes place is particularly important when it comes to analyzing the incidence of subnational level corporate taxes. If the wage is set at the sector-level and the sector includes firms in many jurisdictions, it is unlikely that a change in the local tax rate of one jurisdiction has a large effect on 
wages. By contrast, if wages are set at the firm-level, a local tax change will have a larger impact on wages.

In Appendix A, we consider both firm and sector-level collective bargaining. We do so in a model where firms employ workers of different skill levels. Each skill group is represented by a trade union. In the case of firm-level bargaining, we use the efficient bargaining model (McDonald and Solow, 1981), where unions and individual firm owners bargain over wages and employment. We denote the premium over the reservation wage achieved through bargaining multiplied with the number of workers in a skill group as the rent of the skill group. In the Appendix, we derive

Result 3: Firm-level bargaining: If either wage costs or capital costs are less than fully deductible, an increase (decline) in the local corporate tax rate reduces (increases) the rent of each skill group. For given levels of employment the wage rate declines (increases) in response to an increase (decrease) in taxes ("direct effect" of a corporate tax change on wages).

This result is similar to that of individual bargaining. Higher taxes reduce the rent that can be shared between the firm and its employees. For given levels of employment, wages unambiguously decline in response to a tax increase. In the literature, this effect has been referred to as the 'direct effect' of a corporate tax change on wages in firms where wages are set via collective bargaining (Arulampalam et al., 2012; Fuest et al., 2013). Taking into account changes in employment may change the wage effect (indirect effect). If the number of employees declines in response to a tax increase, the rent generated by the company is shared among a smaller number of employees.

We now turn to models where collective bargaining takes place at the sector-level. The efficient bargaining model used for firm-level bargaining is less suitable for sector-level bargaining because bargaining over employment at the sector-level is difficult. We therefore use the seniority model proposed by Oswald (1993). The seniority model assumes that union decisions are dominated by members who are interested in maximizing wages and who are indifferent about the number of employed workers. As a consequence, a sector-level union wants to maximize the sector wide wage rate while the employer representation has the objective to maximize sector wide profits. After wages are determined, firms set the profit maximizing level of employment. In such a setting, we derive

Result 4: Sector-level bargaining: If either wage costs or capital costs are less than fully deductible, an increase in the tax rate may increase or decrease wages. The wage effect converges to zero if the activity of the sector in the jurisdiction where the tax change occurs is small, relative to the rest of the sector.

If wages are determined at the sector-level, and if the sector is present in many 
jurisdictions, it is likely that a tax change in one jurisdiction will have a limited effect on the sector wide wage. Nevertheless, it is still true that higher taxes reduce the after-tax rent that is shared between firm owners and employees. How the decline in the rent is translated into changes in wages and employment is theoretically ambiguous, as in the case of firm-level bargaining.

Overall, the theory of collective bargaining does not generate unambiguous predictions for how tax changes affect wages. In the empirical analysis, therefore, it would be advisable to allow for differences in incidence effects for firm and sector-level bargaining. If wages are set at the sector-level, a tax change should have a smaller effect on wages in the jurisdiction than in the case where wage bargaining takes place at the firm-level. ${ }^{18}$

\subsection{Corporate tax incidence in fair wage models}

In fair wage models the wage is usually assumed to be a function of i) wages of other employees of the same firm, ii) an external reference wage ${ }^{19}$, which can be the average wage level paid in other firms, a statutory minimum wage or a transfer to the unemployed, and iii) profits of the firm (see, e.g. Akerlof and Yellen, 1990). In general, employees of a profitable firm will expect higher wages than those of a less profitable firm (see e.g. Amiti and Davis, 2010; Egger and Kreickemeier, 2012). If higher corporate taxes reduce after-tax profits, fairness considerations would suggest that employees will bear part of this burden and vice versa. In Appendix A, we develop a simple fair wage model which leads to

Result 5: Fair wage model: An increase (decline) in the local corporate tax rate reduces (increases) the wages of all skill groups.

Note that Result 5 is independent of whether or not wage and capital costs are fully deductible from the tax base. The neutrality property of cash flow taxes does not hold here because wage fairness is assumed to depend directly on after-tax profits. The fair wage model would also imply that collective wage bargaining may spill over to firms without bargaining if they take the bargained wage as a reference point for fairness. This could include wages in firms that do not pay the tax. Moreover, the model predicts that the wage effects increases with the profitability of the firm.

\footnotetext{
18 Some labor markets are characterized by two tier bargaining, where sector-level bargaining sets a minimum wage and wage premiums on top of the minimum wage are negotiated at the firm-level (Boeri, 2014). In a such a setting, one would expect local tax changes to have a more significant impact on local wages than in the case of pure sector-level wage bargaining.

${ }^{19}$ We assume that the reference wage is given. it may of course be the case that the reference wage is affected by local tax changes. This would not alter the result that higher taxes lead to lower wages and vice versa.
} 


\subsection{Corporate tax incidence in models where wages affect labor productivity}

Some labor market models emphasize that firms may raise wages because higher wages lead to higher labor productivity and, hence, higher output. These models include efficiency wage models, where higher wages lead to more effort or lower worker fluctuation, and models of directed job search, where higher wages lead to better matches between workers and firms. ${ }^{20}$ In Appendix A, we suggest a model where higher wages increase the expected output of a firm because higher wages lead to better matches between workers and firms (Acemoglu and Shimer, 1999). ${ }^{21}$ In this model, we derive

Result 6: Models where wages affect productivity: If either wage costs or capital costs are less than fully deductible, an increase (decline) in the local corporate tax rate reduces (increases) wages.

Result 6 can be explained as follows. The optimal wage trades off higher expected output, which is taxed at the corporate tax rate $\tau$, against the cost of higher wages, where the tax deduction granted per unit of wage costs is $\phi \tau$. In the presence of imperfect deductibility $(\phi<1)$, a tax rate increase by $d \tau$ reduces the after-tax benefit of a higher expected output by a factor $d \tau$ and reduces the after-tax cost of wages only by $\phi d \tau$. It is therefore optimal for the firm to adjust its wage policy towards lower wages and a lower quality of worker firm matches. Although the economic forces driving the wage setting are different from those of wage bargaining models, the role of the tax deductibility of wage costs is similar. In the polar case of perfect deductibility, corporate tax changes do not affect wages.

\subsection{Monopsonistic labor market}

The model of monopsonistic labor markets is another widely used framework. To the best our knowledge, it has, however, yet to be used to study corporate tax incidence. In Appendix A, we suggest a simple model of a monopolistic labor market with a constant elasticity of labor supply and a constant marginal productivity of labor. ${ }^{22}$ In this

20 The key difference to the fair wage model discussed in the preceding section is that the latter emphasizes the direct link between the profits of a firm and the wage that is perceived to be fair. No such direct link exists here. However, fair wage models may also be considered as models where wages affect labor productivity because wages deemed as unfair would reduce worker effort or increase costly fluctuation.

21 The results would be similar in an efficiency wage model following Solow (1979) with continuous effort. In shirking models with discrete effort (such as Shapiro and Stiglitz, 1984) we would not expect a direct effect on wages (for given employment) but only an indirect effect though changes in unemployment rates and hence the shirking constraint.

${ }^{22}$ In the Appendix, we also consider a more general model where we relax the assumptions of a constant marginal productivity of labor and a constant elasticity of labor supply. We also add capital to the model. 
framework we derive

Result 7: Monopsonistic labor market: If either wage costs or capital costs are less than fully deductible, an increase (decline) in the local corporate tax rate reduces (increases) wages. The magnitude of the effect is increases with the elasticity of labor supply.

Result 7 suggests that in monopsonistic labor markets groups of employees with a higher elasticity of labor supply may paradoxically bear a higher share of the corporate tax burden. This is because in monopsonistic wage settings, the wage is a share of the marginal productivity of labor after-taxes. This share increases with the elasticity of labor supply because a higher elasticity makes it more difficult for the firm to exploit its market power. The higher share of the marginal product received by workers also means that they lose more if the marginal product after-taxes declines.

\subsection{Extensions}

In this section, we consider two extensions of the model that are both related to particular aspects of corporate taxation. The first extension takes into account that firms may operate in more than one jurisdiction. Many countries use formula apportionment to allocate corporate profits to different jurisdictions for taxation purposes. The second extension is to allow for tax avoidance through income shifting between profits and wages or between high and low tax jurisdictions.

\subsubsection{Firms operating in multiple jurisdictions with formula apportionment}

Consider a firm $i$ with plants in 2 jurisdictions and assume for simplicity's sake that there is only one type of labor and that payroll is the only apportionment factor. ${ }^{23}$ In this case, the firm's profit tax rate is given by $\tau_{i}=\frac{\tau_{1} w L_{1}+\tau_{2} w L_{2}}{w L_{1}+w L_{2}}$. If a jurisdiction increases its tax rate, the effect on the firm's profit tax rate $\tau_{i}$ can be small, depending on how the firm's payroll is distributed across jurisdictions. How such a tax change affects wages and employment depends on the labor market setting and in particular on wage setting institutions. In Appendix A, we analyze the case of firm-level collective bargaining since this case is particularly relevant for our empirical analysis. We derive

Result 8: Formula apportionment and firm-level bargaining: In firms with plants in many jurisdictions and homogeneous labor, where corporate taxation is based on formula

We show that the wage rate still unambiguously declines in response to a tax increase.

23 This is the case for the local corporate tax in Germany. In the US, apportionment for state taxes is based on payroll, sales and assets, see Suárez Serrato and Zidar (2014). The case for two skill types is discussed in Appendix A. 
apportionment, and if wages are set via collective bargaining at the firm-level and either wage or capital costs are less than fully deductible, an increase in the corporate tax rate in one jurisdiction decreases wages in the entire firm. If employment in the jurisdiction that changes the tax rate is small, relative to employment in the firm as a whole, the tax effect is also small.

In the Appendix, we also consider the case of formula apportionment with two skill types. In this case, the wage effect of corporate tax changes is ambiguous since wage changes influence the effective tax rate of the firm, which in turn influences the bargaining process. In the empirical analysis, the role of formula apportionment is investigated by distinguishing between single and multi plant firms.

\subsubsection{Income shifting to avoid taxes}

Income shifting to avoid taxes may occur in different forms. Multinational firms can use debt or transfer pricing to shift profits across national borders, from high to low tax jurisdictions. This type of income shifting will dilute the effect of corporate tax changes on wages because the tax base becomes smaller. However, income shifting may also occur between different tax bases within a country. For instance, firm owners may shift income between the corporate and the personal income tax base by changing wages paid to family members. In this case, a higher corporate tax rate would lead to higher, not lower reported wages. In Appendix A, we extend our model to allow for income shifting. As done in the preceding section, we again focus on the case where wages are set via firm-level bargaining. ${ }^{24}$ This leads to

Result 9 Income shifting: If firms engage in international income shifting and wages are set by firm-level bargaining, then the decline in the rent accruing to labor caused by a higher corporate tax decreases as the equilibrium level of income shifting increases. If firms can shift income between the profit tax base and the labor income tax base, reported wages will decline less than in the absence of income shifting or may even increase in response to a higher corporate tax rate.

Result 9 implies that one would expect the observed effect of corporate tax changes on wages to be smaller in multinational firms, where the tax impact is diluted by profit shifting to other jurisdictions. Income shifting between the profit and the labor income tax base within a jurisdiction would bring lower wage declines or even increases in response to higher corporate taxes. This is likely to be relevant in very small firms, where higher taxes on profits induce firm owners to report a higher share of profits as wages paid to family

\footnotetext{
24 As we explain in the appendix, income shifting between profits and wages may occur in the form of manipulating wages paid to family members of the owner employed by the firm. These wage payments are not determined via bargaining; rather they are effectively hidden profit distributions.
} 
members employed by the company and where these employees represent a significant share of the workforce.

\section{Institutional background}

We test the implications of our theoretical analysis exploiting the particular features of the German corporate tax system. In Section 3.1, we briefly sketch the German business tax system in general. Special emphasis is put on the local business tax (LBT, Gewerbesteuer). This tax creates quasi-experimental variation in tax rates and is used for identification in the empirical part of the paper. The key features of the nationwide corporate and personal income taxes, the other two profit taxes in Germany, are described in Appendix B. In Section 3.2, we document the cross-sectional and time variation of the LBT. Subsection 3.3 briefly discusses labor market institutions in Germany.

\subsection{Business taxation in Germany}

In 2007, profit taxes accounted for about $6.2 \%$ of total tax revenue (including social security) in Germany (OECD, 2015) which is below the OECD average of about 10.6\% (US: 10.8\%, UK 9.4\%). ${ }^{25}$ There are three taxes on business profits in Germany, the LBT, which is set by municipalities, the corporate tax (CT, Körperschaftsteuer) and the personal income tax (PIT, Einkommensteuer), the latter two being levied by the federal government. Corporate firms are liable to the LBT and the CT, while non-corporate firms are liable to the LBT and the PIT. In terms of tax revenues, the LBT is the most important profit tax, accounting for about $60-70 \%$ of total profit tax revenues from corporate firms. The share of profit tax revenues from local taxes is relatively high in Germany compared with other countries. In the US, for instance, state and local corporate taxes together account only for about $20 \%$ of total corporate taxes (NCSL, 2009). In addition, the LBT is the most important source of financing at the disposal of municipalities, generating roughly three quarters of municipal tax revenue.

The LBT applies to both corporate and non-corporate firms, while most firms in the agricultural and public sector are not liable. Moreover, certain liberal professions such as journalists, physicians or lawyers are exempt. The tax base of the LBT is similar to that of the corporate income tax. ${ }^{26}$ Taxable profits of firms with establishments in more than

\footnotetext{
${ }^{25}$ Part of this relatively low share is due to the high importance of social security contribution (SIC) in Germany which is among the highest in the OECD. If SIC are excluded, the share in total taxes is about $11.5 \%$.

${ }^{26}$ The most important difference is that interest payments are only partly deductible. Another difference is that the LBT itself was a deductible expense until 2007.
} 
one municipality are divided between municipalities according to formula apportionment based on the payroll share.

The tax rate of the LBT, $\tau_{L B T}$, consists of two components: the basic federal rate (Steuermesszahl), $\tau_{L B T}^{f e d}$, which is set at the national level, and the local tax rate (Hebesatz), $\tau_{L B T}^{m u n}$, which is set at the municipal level. The total LBT rate is given by $\tau_{L B T}=\tau_{L B T}^{f e d} \cdot \tau_{L B T}^{m u n}$. The basic federal rate, $\tau_{L B T}^{f e d}$, was at $5.0 \%$ from 1993 to 2007 and decreased to $3.5 \%$ in 2008 . The average local tax rate over our sample period (1993 2012) was $328 \%$, yielding a total tax rate of $15.1 \%$.

The local tax rates for year $t$ are set by the municipal councils during the budgeting process in the last three months of year $t-1$. Each year the city council has a vote about next year's tax rate - even if it remains unchanged. It is important to note that a municipality can adjust only the local tax rate that applies to all firms in the municipality. It can not change the tax base, which is set at the federal level.

\subsection{Variation in local business tax rates}

In this subsection, we provide a detailed description of the variation in LBT rates. For our analysis, we use administrative statistics provided by the Statistical Offices of the 16 German federal states (Statistische Landesämter) on the fiscal situation of all municipalities. We combine and harmonize the annual state specific datasets and construct a panel on the universe of all municipalities from 1993 to 2012, covering 228,820 municipality years. Most importantly, the dataset contains information on the local tax rate, but also on the population size and municipal expenses and revenues. We also add data from the German federal employment agency on regional unemployment rates on the more aggregate county (Kreis) level to control for local labor market conditions.

Figure 1 depicts Germany's 11,441 municipalities (according to 2010 boundaries) and visualizes the substantial cross-sectional and time variation in local tax rates. The left panel of the figure shows the cross-sectional variation in local tax rates in 2008 with darker colors showing higher tax rates. Table C.1 in the appendix provides measures of the distribution of LBT rates annually from 1993 to 2012. For the entire period, the average local tax rate is $328 \%$, while tax rates typically vary between $275 \%$ (P5) and $395 \%$ (P95).

We exploit the within-municipality variation in local tax rates over time to identify the business tax incidence on wages. The right panel of Figure 1 demonstrates this variation by showing the number of tax changes a municipality during the period 19932012 (with darker colors indicating more changes). Table C.2 in the Appendix shows the corresponding numbers. Overall, only $15 \%$ of the municipalities did not experience a tax 
Figure 1: Cross-sectional and time variation in local tax rates
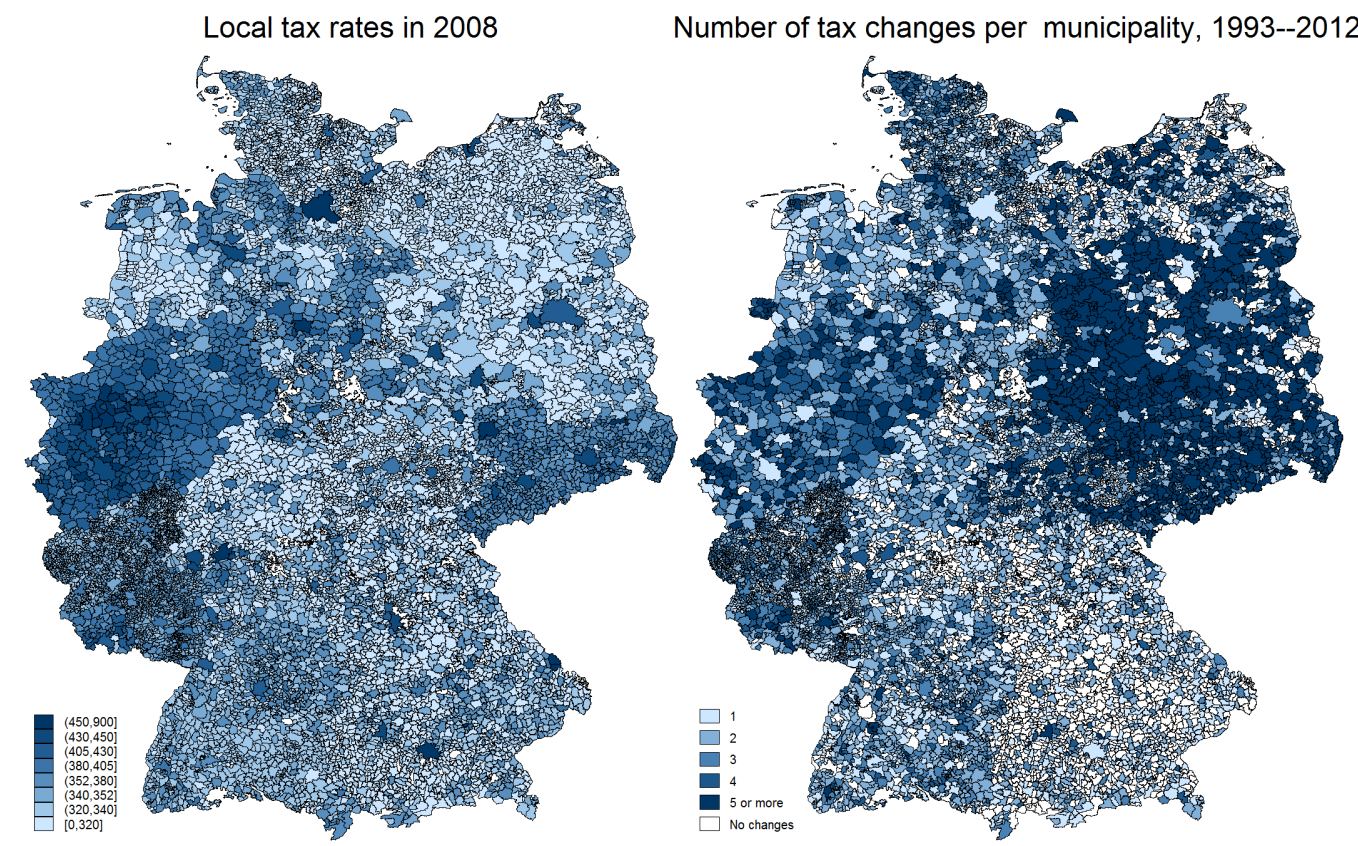

Source: Statistical Offices of the Länder. Notes: Jurisdictional boundaries as of December 31, 2010.

rate change during this 20-year period. More than half of the jurisdictions have changed the tax rate once or twice, and roughly $15 \%$ experienced 4 or more tax changes.

In terms of geographic distribution, a striking pattern is that East German municipalities have changed tax rates more frequently than West German jurisdictions. The reason for this imbalance is related to jurisdictional changes occurring in East Germany after reunification. East German municipalities were rather small in 1990 and were subsequently merged (sometimes even several times) to bigger jurisdictions. Until 2010, 47\% of the existing East German municipalities have undergone jurisdictional changes. By contrast, in West Germany, only 0.6\% (52) municipalities changed boundaries since 1992.

In our administrative wage data (described in Section 4.2), we only observe municipal boundaries as of 2010. Therefore, if several municipalities have been merged, we do not know in which of them a firm was located prior to the merger. The only option to match municipal information to the wage data in such a case is to bring the tax data to the boundaries of 2010. But this generates artificial and flawed variation in tax rates in merged municipalities (by, say, assigning the weighted average tax rate of previous municipalities to the merged jurisdiction). ${ }^{27}$ Given this measurement error in tax rate changes, we

27 This also explains the high number of (small) tax changes in East Germany. Table C.3 in the Appendix shows that on average $12.4 \%$ of the municipalities change their tax rate per year. Among the 
focus on non-merged municipalities in our baseline analysis (and check whether results for merged and non-merged municipalities differ). Due to this restriction, we are left with about 10,000 municipalities and 18,000 tax changes for identification (instead of 11,441 municipalities with about 27,000 partly artificial tax changes).

Table C.3 shows that $94 \%$ of tax changes are tax increases, with the average increase being 23 percentage points (of $\tau_{L B T}^{m u}$ ). ${ }^{28}$ Evaluated at the mean local tax rate of $328 \%$ and for a given federal business tax rate, this rise implies an increase of the total business tax rate by $7 \%$ (or 1.15 percentage points for an average total tax rate of $16.4 \%$ ). Hence, we exploit quite a few tax reforms with fairly large scopes for identification.

\subsection{German labor market institutions}

As our theoretical predictions depend on underlying wage setting institutions, we briefly describe the German labor market. ${ }^{29}$ Traditionally, German labor unions have been very influential. Collective bargaining agreements (CBAs) at the sector-level are the most important mechanism for wage determination. Nevertheless, there has been a significant decline in bargaining coverage. In West (East) Germany, CBA coverage decreased from $76 \%(63 \%)$ in 1998 to $65 \%(51 \%)$ in 2009 . The share of workers covered by sectoral agreements fell from $68 \%(52 \%)$ to $56 \%$ (38\%) (Ellguth et al., 2012). ${ }^{30}$ In addition to sector-level CBA, some firms have firm-level agreements, while other firms are not covered by a CBA and rely on individual contracts with each employee.

The average duration of a CBA increased from 12 months in 1991 to 22 months in 2011. Usually, negotiations take place in the first half of a year. Firms may pay wages above those negotiated in CBAs. Note that except for a few industries, there was no legal minimum wage in Germany during our period of analysis. However, the social security and welfare system provides an implicit minimum wage and CBAs ensure that wages are above that level.

merged municipalities, however, the share is $33 \%$ (with a much smaller average change).

${ }^{28}$ In light of the vast international evidence of decreasing tax rates for companies, this seems surprising at first sight. Yet, both the CT rate and the top PIT rate decreased over the period 1993-2012 so that the overall tax rate for companies decreased as well (see Appendix B for more details). Thus, a rise in the LBT rates in a municipality over time has to be seen as a slower decrease in overall tax burdens for firms in these municipalities than with those of firms in other jurisdictions with stable local tax rates.

29 See, e.g., Dustmann et al. (2014) for an overview and analysis of the development of German labor market institutions during our period of investigation.

${ }^{30}$ Coverage rates vary by industry: collective bargaining is slightly above average in the manufacturing sector, while the highest coverage is in the public sector and the lowest in ICT, agriculture and restaurant industries). Overall, union coverage rates in Germany are lower than in other European countries - except the UK and some Eastern European countries - but higher than in the US (Du Caju et al., 2008). 


\section{Empirical strategy and data}

\subsection{Empirical model and identification}

We implement an event study design to estimate the effect of changes in the local tax rate on wages. Our baseline outcome variable is the log median real wage in firm $f$, municipality $m$, and year $t, w_{f m, t}^{p 50}$. Note that each municipality is nested in a county $c$, commuting zone $r$ and state $s$. We choose the median as the baseline to account for the top-coding of wages at the ceiling for social security contributions, which affects up to $13 \%$ of wage earners (see the discussion in the next subsection). Nevertheless, we also use the $25 \%$ percentile and the $75 \%$ percentile as well as the mean wage as outcome variables to assess the distributional effects of the reform and check the sensitivity of our estimates.

In the context of our study, we make two adaptations to the conventional event study design (Sandler and Sandler, 2014). First, we take into account that there may be multiple tax changes over time per municipality. Second, tax changes differ in size (and sign). Hence, instead of regressing the wage in period $t$ on dummy variables indicating tax reforms, we multiply the reform dummies with the respective tax rate change. Formally, our model reads:

$$
\begin{aligned}
\ln w_{f m, t}^{p 50} & =\gamma_{-b} \sum_{i=b}^{B-t} \Delta \tau_{m, t+i}+\sum_{j=-b+1}^{a-1} \gamma_{j} \Delta \tau_{m, t-j}+\gamma_{a} \sum_{k=a}^{t-A} \Delta \tau_{m, t-k} \\
& +\mu_{f}+\mu_{m}+\mu_{t}+\varepsilon_{f m, t}
\end{aligned}
$$

The coefficients of interest are the $\gamma$ 's, which measure the wage effect in $t$ of tax reforms occurring in the event window between $t-a$ years in the past to $t+b$ years in the future. The regressor $\Delta \tau_{m, t+j}$ is the change in the local tax rate of municipality $m$ from $t+j-1$ to $t+j{ }^{31}$ Given wage data from 1998 to 2008 (see Section 4.2), we set $b=4$ and $a=5$ allowing us to cover ten years around a tax reform occurring in period $t=0 .{ }^{32}$ A pre-treatment period of 4 years seems long enough to detect potential pre-trends while 5 years after treatment suffice to look beyond the short-run effects of the reforms. ${ }^{33}$ We adjust the ends of the event window (coefficients $\gamma_{-b}$ and $\gamma_{a}$ ) to take into account tax changes that are outside of the event window, which runs from $t-a$ to $t+b$. The first and the last data year are denoted $A$ and $B$, respectively. Given our sample, it

\footnotetext{
${ }^{31}$ Note that this is equivalent to taking a dummy variable indicating a tax rate change from $t+j-1$ to $t+j$ and interacting it with the corresponding change.

32 The choice of this event window implies that we need tax data from 1993 until 2012, see Section 3.2.

33 We experimented with different leads and lags, but the results proved to be stable.
} 
follows that $A=1993, B=2012$. The specification makes the set of $a+b+1$ regressors perfectly collinear. We drop the regressor for the pre-reform year (and normalized it to zero). Hence, all coefficients have to be interpreted relative to the pre-reform year. We also include municipal, $\mu_{m}$, firm, $\mu_{f}$, and year fixed effects $\mu_{t}$, to our equation. ${ }^{34}$ The error term is denoted by $\varepsilon_{m, t}$.

In order to test for heterogeneous effects, we interact the tax rate changes $\Delta \tau_{m, t+j}, j=$ $-b, \ldots, a$, with firm or worker characteristics. Note that some of those characteristics such as collective bargaining agreement or single vs. multi establishment firm are potentially endogenous and may respond to the tax rate. For this reason, we fix the characteristics to the values of 1997 , i.e., the year prior to our first panel observation.

Identification Given that the model includes firm and municipal fixed effects, we identify the effect of tax changes on wages within firms and municipalities over time. We thus estimate a variant of a difference-in-differences model with fixed effects. As usual, the $\gamma$ coefficients measure the causal effect of local tax rates on wages provided that there is neither reverse causality nor omitted variable bias.

The coefficients on future tax changes can be used to directly check for reverse causality problems in the spirit of a Granger test. Identification requires a flat trend that is, no statistically significant wage responses - preceding a tax reform. With respect to omitted confounders, our research design would be invalid if local shocks systematically affected tax rates and wages. We provide two checks to assess whether such potential local shocks are likely to bias our estimates. First, we run event study designs as specified in equation (2) using municipal unemployment, county GDP and municipal fiscal surplus as outcome variables. Significant pre-treatment trends for these outcomes would hint at local shocks and cast doubt on our identifying assumption. As will be shown in Section 5.1 , there are no local shocks to the business cycle prior to a tax reform.

As a second test, we enhance the model shown in equation (2) to directly take into account local shocks. Instead of including simple year fixed effects, we include "state $\times$ year" fixed effects - which account for any shock omitted at the state-level, such as municipal election years, which have recently been shown to affect LBT rates (Foremny and Riedel, 2014). In a more involved specification, we include fixed effects "commuting zone $\times$ year". German municipalities are nested in 258 commuting zones, which are delineated by commuter flows. Adding these $258 \cdot 11=2838$ dummy variables, takes out annual labor market shocks at the local level. Besides these purely non-parametric specifications, we also estimate a model where we directly account for local time-varying

\footnotetext{
${ }^{34}$ Note that firm and municipal fixed effects are highly collinear as only very few firms move between municipalities in the data.
} 
confounders by adding lagged county GDP, unemployment and municipal revenues to equation (2). If there was an omitted variable problem in our baseline specification, we would expect coefficients to change substantially after controlling for these variables as they should be correlated with local shocks.

Worker level estimations. We also implement an event study design at the individual level to test for heterogeneous effects. The empirical model for the worker-level equations is defined as follows:

$$
\begin{aligned}
\ln w_{i f m, t} & =\gamma_{-b} \sum_{i=b}^{B-t} \Delta \tau_{m, t+i}+\sum_{j=-b+1}^{a-1} \gamma_{j} \Delta \tau_{m, t-j}+\gamma_{a} \sum_{k=a}^{t-A} \Delta \tau_{m, t-k} \\
& +\mu_{i}+\mu_{f}+\mu_{m}+\psi_{t}+\varepsilon_{i f m, t}
\end{aligned}
$$

Here the outcome variable is the log wage of individual $i$, working in firm $f$ that is situated in municipality $m$. We also add individual fixed effects to the model, so identification remains within individual-firm-municipality combinations. ${ }^{35}$

Inference. Usually, we cluster standard errors at the municipal level, i.e. the level of our identifying variation. Given the well-known problems of biased standard errors in difference-in-difference models (Bertrand et al., 2004), we conduct two tests to assess the sensitivity of our estimates: First, we aggregate the data to the municipal level and reestimate equation (2) finding similar results. Second, we follow the suggestions by Angrist and Pischke (2009) to "pass the buck up one level" and cluster standard errors on a higher level of aggregation, which in our case is the county or the commuting zone. Standard errors of estimates are hardly affected (see Appendix D for both checks).

\subsection{Linked employer-employee data}

We combine the administrative municipal data presented in Section 3.2 with linked employer-employee data (LIAB) provided by the Institute of Employment Research (IAB) in Nuremberg, Germany (Alda et al., 2005). The LIAB combines administrative worker data with firm-level data.

The firm component of the LIAB is the IAB Establishment Panel (Kölling, 2000), which is a stratified random sample of all German establishments. The term establishment

\footnotetext{
35 Technically, we apply the spell fixed-effects estimator suggested by Andrews et al. (2006) when estimating equations (2) and (3) and de-mean variables within each unique (worker-)firm-municipality combination.
} 
refers to the fact that the observational unit is the individual plant, not the firm. The employer data covers establishments with at least one worker subject to social insurance contributions. The sample covers about 15,000 establishments, which corresponds to about $1 \%$ of all German establishments. We extract the following variables: value added, investment, number of employees, industry, total wage bill, legal form, union wage status (industry, firm or no collective agreement) and self-rated profitability ${ }^{36}$

In addition to the plant-level information, the data set contains information on all employees in the sampled establishments. The employee data is taken from the administrative employment register of the German Federal Employment Agency (Bundesagentur für Arbeit) covering all employees paying social security contributions (Bender et al., 2000). ${ }^{37}$ The employee information are recorded on June 30th of each year and include information on wages, age, tenure, occupation, employment type (full-time or part-time employment) and qualification. Individuals with missing information are excluded. Our worker panel consists of between 1.6 and 2.0 million workers (corresponding to about $6 \%$ of all workers) annually observed from 1998 to 2008. The choice of years is driven by data availability for the tax rate data to allow for a sufficient number of years before and after the tax reforms. Furthermore, ending in 2008 avoids the effects of the Great Recession.

Importantly, wages are right censored at the ceiling for social security contributions. Although the ceiling is quite high, with annual labor earnings of 63,400 euros in 2008 for Western Germany, up to $13 \%$ of the observations are censored. Note that the censoring does not affect results on the firm-level since we use the median wage in the establishment as our left-hand-side variable. At the individual level, we opt for a conservative approach and assign censored individuals the cap leading to an underestimate of the wage effect. As a sensitivity check, we exclude all individuals who at least once earned a wage above the contribution ceiling during the observation period. ${ }^{38}$ As shown below, this exclusion affects the results for high-skilled workers. ${ }^{39}$

36 The survey question asks for a self-assessment of the profit situation on a five-point scale ranging from very good to unsatisfactory. We pool the two answers "very good" and "good" as well as "fair" and "poor" and construct a three-point scale (high, medium, low) for profitability with well-balanced support over the three categories.

${ }^{37}$ Note that civil servants, self-employed individuals and students are not observed in the social security data. The data nonetheless contain more than $80 \%$ of all employed persons in Germany.

38 Imputing censored wages is a third option used in the literature (Dustmann et al., 2009; Card et al., 2013). While imputing censored wages using a Tobit procedure is sensible when analyzing wage inequality, it is problematic in our study, in which we use the individual wage as the left-hand-side variable. In fact, the LBT rate would have to be a regressor in both the Tobit model and the even study design.

39 We differentiate between three skill groups: high-skilled workers who have obtained a college/university degree; medium-skilled who have completed either vocational training or the highest high school diploma (Abitur); low-skilled who have completed neither of the two. 
Descriptive statistics. Appendix Tables C.4, and C.5 present descriptive statistics of our plant and worker level sample. ${ }^{40}$ Table C.4 shows that the average median firm wage is 2,555 euros. $15 \%$ of our municipality-year observations have undergone either a tax increase or a tax decrease, with an average local tax rate of $371 \%$. The average (median) size of the municipality is $98,613(26,456)$ inhabitants. About three quarters of the sample are municipalities that have not undergone a merger between 1993 and 2012. The average (median) plant has 239 (52) employees. $64 \%$ of the plants are liable to the LBT and about $60 \%$ of the firms are liable to the corporate tax. Most of the establishment are single-plant firms. More than half of the firms have sector-level bargaining agreements in place.

Not surprisingly, we observe more workers in larger firms. As larger firms pay higher wages, we see that the average wage in the individual level sample increases to 3,358 euros per month (see Table C.5). The average (median) number of workers increases to 4,875 (908). In terms of individual characteristics, the table shows that the average worker in our sample is 42 years old. The share of males is $71 \%$. $14 \%$ of the individuals are high skilled, while about as many are low-skilled. $83 \%$ of the individuals have never earned a wage higher than the social security contribution cap in our sample.

\section{Empirical results}

In this section, we estimate the incidence of corporate taxation on wages. Before turning to our main results, we test our identifying assumption by analyzing whether local productivity shocks affect tax rate changes.

\subsection{Drivers of local tax rate changes}

While it is common to use variation in policies across regions and over time to identify policy effects, the approach requires the exogeneity of the policy change with respect to the outcome variables. A particular concern in our setting is whether tax rates respond to local business cycle shocks, which could also affect wages. ${ }^{41}$ Analyzing pre-trends in our event study design provides a first test of the identifying assumption. As will be shown below, wage rates do not change significantly prior to tax changes. In addition, we can test directly for violations of the identifying assumptions by using local economic outcomes as left-hand-side variables in the event study model. In particular, we test

\footnotetext{
${ }^{40}$ In the baseline, we only consider full-time workers. We also looked at the effects on part-time wages but find no significant differences, see the discussion in Section 5.4.

${ }^{41}$ Previous evidence for the German LBT (Foremny and Riedel, 2014) as well as for income tax reforms in Europe (Castanheira et al., 2012) suggest that tax changes are typically triggered by political concerns, not economic variables.
} 
whether unemployment, GDP and fiscal surplus change prior to tax reforms.

Panel A of Appendix Figure D.5 shows that municipal unemployment levels are flat prior to a tax reform. Similarly, Panel A of Appendix Figure D.6 shows no significant pre-trends for GDP. ${ }^{42}$ While we find no evidence of significant pre-trends, we do find that county GDP declines after the reform. Likewise, there is an increase in unemployment rates. However, while both effects are statistically significant, they are economically very small in magnitude (each change being about $0.02 \%) .{ }^{43}$

In Panel B of Appendix Figure D.6, we show the evolution of fiscal surpluses per capita before and after a tax change. While pre-trends are again remarkably flat, we find a small and insignificant increase of 18 euros per capita in the fiscal surplus in the year of the tax increase. It seems that this fiscal surplus will be "eaten up" by a small deficit of 6 euros per capita in years 1 to 3 after a tax increase. While the effect is quite small, we nevertheless include local expenditures in some specifications to test the robustness of our results when accounting for potentially improved public services in a municipality with increasing local tax rates. We find that results do not change in that case.

\subsection{Baseline results}

In this section, we present our main results obtained from estimating equation (2). We present results graphically plotting the $\gamma$ coefficients and the corresponding $95 \%$ confidence intervals. Regression tables are provided in Appendix E. As discussed in Section 3.2 , we focus on the 10,000 municipalities that did not changes jurisdictional borders between 1993 and 2012. ${ }^{44}$ For our baseline estimate, we focus on firms that are liable to the LBT. Figure 2 depicts the results. Pre-reform trends are flat and not statistically different from zero. After a change in the municipal business tax rate in period 0 (indicated by the vertical red line), real wages start to decline and are 0.047 log points below the prereform year five years after the reform. The coefficient corresponds to a wage elasticity with respect to the LBT rate of 0.14. In Section 5.5, we show that this central estimate implies that a 1-euro increase in the tax bill leads to a 0.56 -euro decrease in the wage bill. Figure 2 also contains information about firms that are exempt from the LBT. We find positive yet insignificant wage effects. ${ }^{45}$ In the following, we consider the results for liable

\footnotetext{
${ }^{42}$ Note that local GDP data are available at the county level but not at the municipal level. In order to show that moving to a more aggregate level does not drive the results, Panels A and B of Figure D.5 depict unemployment results when running the analysis on the municipal vs. the county level. There are only small differences.

43 In a companion paper, Siegloch (2013) further investigates the (un)employment effects of the LBT.

44 Nevertheless, we present results for merged municipalities in Figure D.1 in Appendix D.

45 If non-liable firms were not affected at all by the tax increase the difference between the two curves would be the treatment effect. However, we cannot be sure that exempted firms are a valid control group
} 
firms as our baseline estimates and exclude non-liable firms from the sample.

Figure 2: Effects on firm wages - by liability to local business tax

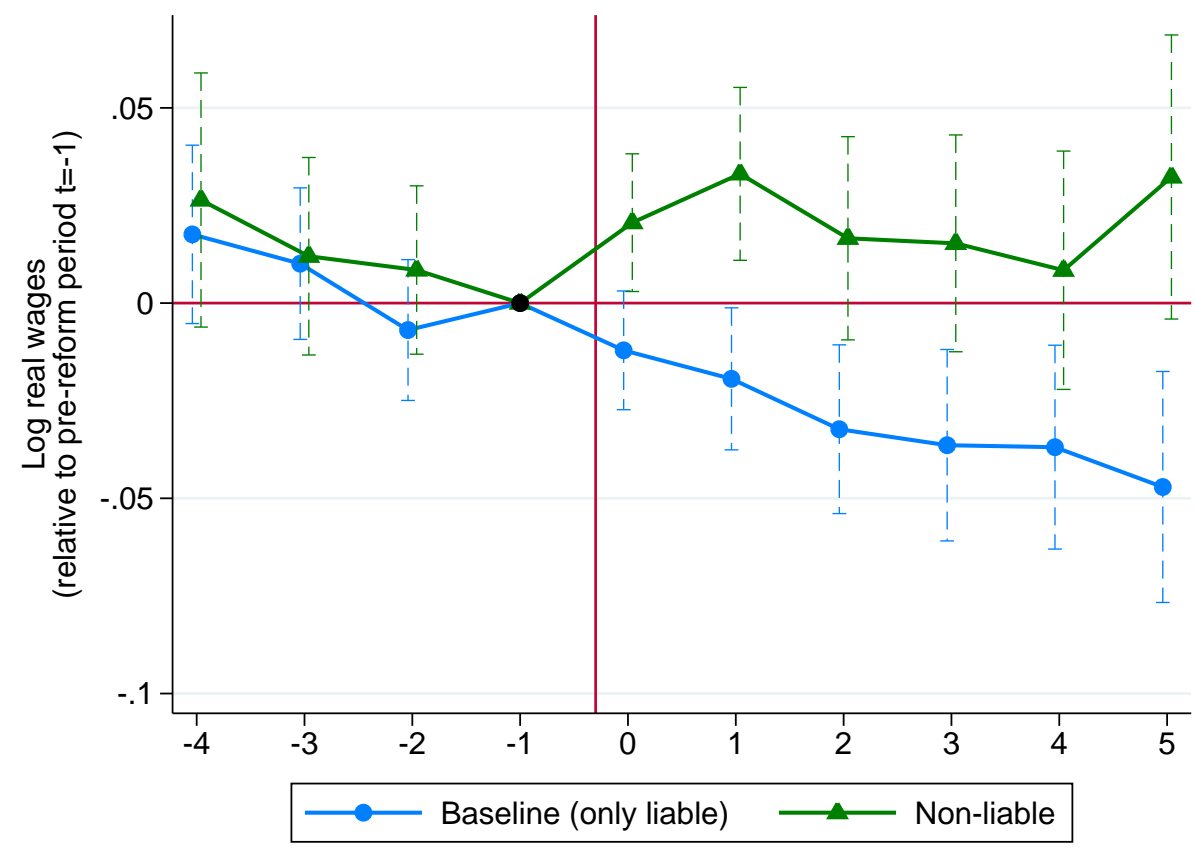

Source: LIAB and Statistical Offices of the Länder. Notes: All curves depict event study estimates $\left(\gamma_{j}, j \in[-4,5]\right)$ and the corresponding $95 \%$ confidence bands obtained by estimating equation (2). The figure presents treatment effects separately for liable and non-liable plants (see legend). The graph shows the evolution of wages in $\log$ points $\left(100 \cdot \gamma_{j}\right)$ before and after a change of the LBT rate. A value of -0.05 implies a wage elasticity with respect to LBT rates of -0.17 (see Section 5.5). The tax reform occurred for the treatment group on 1 January in event year $t=0$, as indicated by the vertical red line. Wages are observed on 30 June for each year. The estimation sample includes all establishments in non-merged municipalities. All regression models include "state $\times$ year" fixed effects and the following local control variables: log municipal revenues, log municipal population, log county unemployment rate, log county GDP (all lagged by two periods). "Firm-type $\times$ year" fixed effects are also included. Standard errors are clustered at the municipal level. Full regression results are shown in Appendix Table E.7.

Next, we check whether our baseline estimate is robust to omitted confounders. Our baseline specification laid out in equation (2) includes "state $\times$ year" fixed effects and lagged municipal controls to account for local shocks. In Figure 3 we plot the coefficients of several specifications, in which we vary the set of control variables. ${ }^{46}$ Hence, the figure provides a test of how sensitive our estimates are to the inclusion of more or less detailed local control variables. In other words, we check how sensitive our estimates are to omitted

as they might benefit from changes in public goods financed through higher taxes or their wage setting behavior might partly be influenced by the wage levels of liable firms in the municipality. For instance, fair wage considerations imply that wage changes in liable firms may spill-over to exempted firms.

46 To be precise, we show results for year fixed effects without controls, "state $\times$ year" fixed effects without controls, "state $\times$ year" fixed effects with municipal controls (our baseline), "commuting zone $\times$ year" fixed effects with municipal controls, as well as "commuting zone $\times$ year" fixed effects with municipal and firm control variables. For the sake of presentation, we do not report the results for the other possible combinations such as "commuting zone $\times$ year" fixed effects without controls or year fixed effects with firm controls, as the results are very robust across specifications. 
confounders such as local shocks. Since it is hard to imagine that unobserved local shocks are not correlated with any of the additional control variables, estimates should vary between the different specifications if local shocks were a concern.

Figure 3: Effects on firm wages - robustness with respect to controls

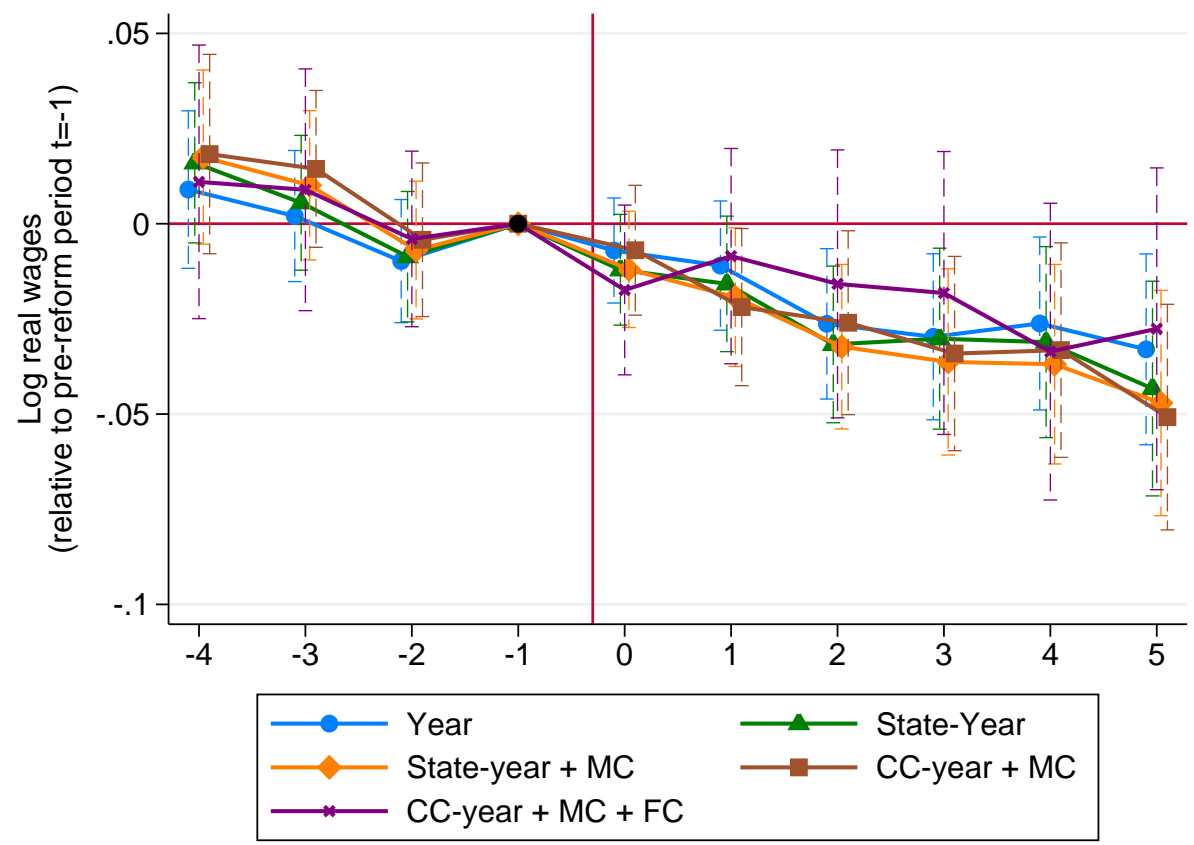

Source: LIAB and Statistical Offices of the Länder. Notes: All curves depict event study estimates $\left(\gamma_{j}, j \in[-4,5]\right)$ and the corresponding $95 \%$ confidence bands obtained by estimating equation (2). The graph shows the evolution of wages in $\log$ points $\left(100 \cdot \gamma_{j}\right)$ before and after a change of the LBT rate. A value of -0.05 implies a wage elasticity with respect to LBT rates of -0.17 (see Section 5.5). The tax reform occurred for the treatment group on 1 January in event year $t=0$, as indicated by the vertical red line. Wages are observed on 30 June for each year. The estimation sample includes all liable establishments in non-merged municipalities. The included control variables and fixed effects (year, "state $\times$ year" or "commuting zone $(\mathrm{CC}) \times$ year") vary depending on the specification (see legend). Municipal controls (MC) are log municipal revenues, $\log$ municipal population, log county unemployment rate, log county GDP (all lagged by two periods). Firm controls (FC) include employment, investment and output (all lagged by two periods). Standard errors are clustered at the municipal level. Full regression results are shown in Appendix Table E.7.

Reassuringly, we find that estimates are very robust across specifications. In fact, both treatment effects and pre-trends only vary marginally when we include year fixed effects instead of "state $\times$ year" fixed effects or even when we add "commuting zone $\times$ year" fixed effects. Moreover, results do not change if we include local business cycle variables, such as GDP, unemployment or municipal revenues. In the last specification, we add (lagged) firm-level control variables such as employment, investment and output. ${ }^{47}$

47 On the one hand, the differences between the estimates with and without firm controls can be seen as a test of the "direct" vs. the "indirect" wage effects (Arulampalam et al., 2012). On the other hand, these control variables are potentially endogenous to taxes (despite being lagged due to, say, serial correlation). Therefore, we refrain from putting too much weight on interpreting the estimates with firm controls. We still present results whenever interesting differences emerge, however. 
Results are again broadly similar with somewhat lower point estimates and larger standard errors. ${ }^{48}$ These are due to interesting differences from industry to industry (see below).

Furthermore, our results are also robust to including future and current municipal expenses as control variables (not shown). Such a specification shuts down one theoretical channel that might lead to a wage response from a tax reform. As discussed in Section 2, higher taxes might lead to higher municipal spending and thus better local public services, which in turn might generate lower wages in the form of a compensating differential. As estimates remain unchanged when adding local controls, this channel does not appear to be empirically relevant in Germany. In comparing all curves, it becomes evident that controlling for local shocks does not affect wage adjustment.

Sensitivity checks. We conduct several sensitivity checks to test the robustness of our baseline results. First, we address the issue of wage censoring. As described in Section 4.2 , wages are censored at the ceiling for social security contributions. For this reason, we choose the log median wage in firm $f$, which is invariant to the censoring, as our left-handside variable. In Figure D.2 in Appendix D, we test whether this choice affects results by using the mean wage in firm $f$ instead of the median. Moreover, we test whether different parts of the wage distribution within firms are affected differently by replacing the log median wage with the log P25 and P75 wage.

Figure D.2 shows the negative wage effects that also arise when using the mean wage at the establishment level. But these effects are smaller, which suggests that wage censoring leads to a downward bias of our estimate. ${ }^{49}$ Moreover, we find that negative wage effects for the top $25 \%$ of wage earners in each firm are significantly lower. There are two potential explanations for this finding. First, while up to $13 \%$ of workers earn wages above the social security contribution ceiling, the share of censored workers might be higher than $25 \%$ in certain firms. If this were the case, lower estimates could have resulted from the downward bias induced by wage censoring. Second, it is possible that higher income earners within a firm are more mobile, which should lead to lower wage responses.

In our baseline model, standard errors are clustered at the municipal level. Given the well-known problems of biased standard errors in difference-in-difference models (Bertrand et al., 2004), we first estimate an event study regression on the municipal level, using the median municipal wage as our left-hand-side variable and clustering at the municipal level. While estimates are a bit more noisy and less stable due to smaller numbers of

\footnotetext{
48 Results are also similar when adding the control variables - either on the municipal or firm-level sequentially or in turn instead of all together.

49 Note that we corroborate this hypothesis below, when running event studies on the worker level.
} 
observations and the fact that the wage measures includes liable and non-liable firms, effects are still comparable (see Figure D.3 in the Appendix). Second, when clustering at higher levels of aggregation, we find that the significance of our estimates hardly changes (see Table D.6 in the Appendix).

\subsection{Heterogeneous firm effects}

In the following sections, we test for heterogeneous firm and worker effects. By doing this we try to get at the underlying mechanisms driving wage responses to tax rate changes and relate these back to our theoretical considerations.

First, we test for differences in terms of industry (Figure 4). Interacting the event dummy regressors with industry dummies, the solid lines in Panel A show that effects for manufacturing and services are quite similar after 4 to 5 years. However, wages in the manufacturing sector seem to respond immediately, while service sector firms start to pay lower wages after 2 to 3 years. These different adjustment paths could be due to different labor market institutions: the labor market in the service sector is much more competitive, while unions are strong in the manufacturing sector. According to our theoretical model, the difference in adjustment paths could be driven by the differences in direct and indirect effects across sectors. While the direct bargaining effect (conditional on factor inputs) can be expected to be more relevant for manufacturing firms, indirect effects induced by changes in factor inputs could dominate in the service sector. To test this hypothesis, we re-estimate the model conditional on output, employment and investment, which empirically shuts down the indirect effect (with the caveats discussed in footnote 47). Indeed the dashed lines in Panel A suggest that the wage effect in the service sector is driven by the indirect effect. By contrast, wage effects in the manufacturing sector are scarcely affected by eliminating production factor adjustments, which suggests that the direct effect is more important in this sector. A possible interpretation of these findings is that wage effects in manufacturing reflect rent sharing while higher taxes induce service sector firms to relocate jobs to other jurisdictions, so that local wages decline.

The sectoral results might also be interpreted as shedding light on the role of price effects in our setting. Comparing the manufacturing sector, which mostly produces highly tradable goods, to the service sector, where goods are arguably less tradable, we see no significant differences in the overall wage response. If price effects indirectly affected wage responses, we should observe differences in wage effects by sector. 
Figure 4: Effects on firm wages - by industry

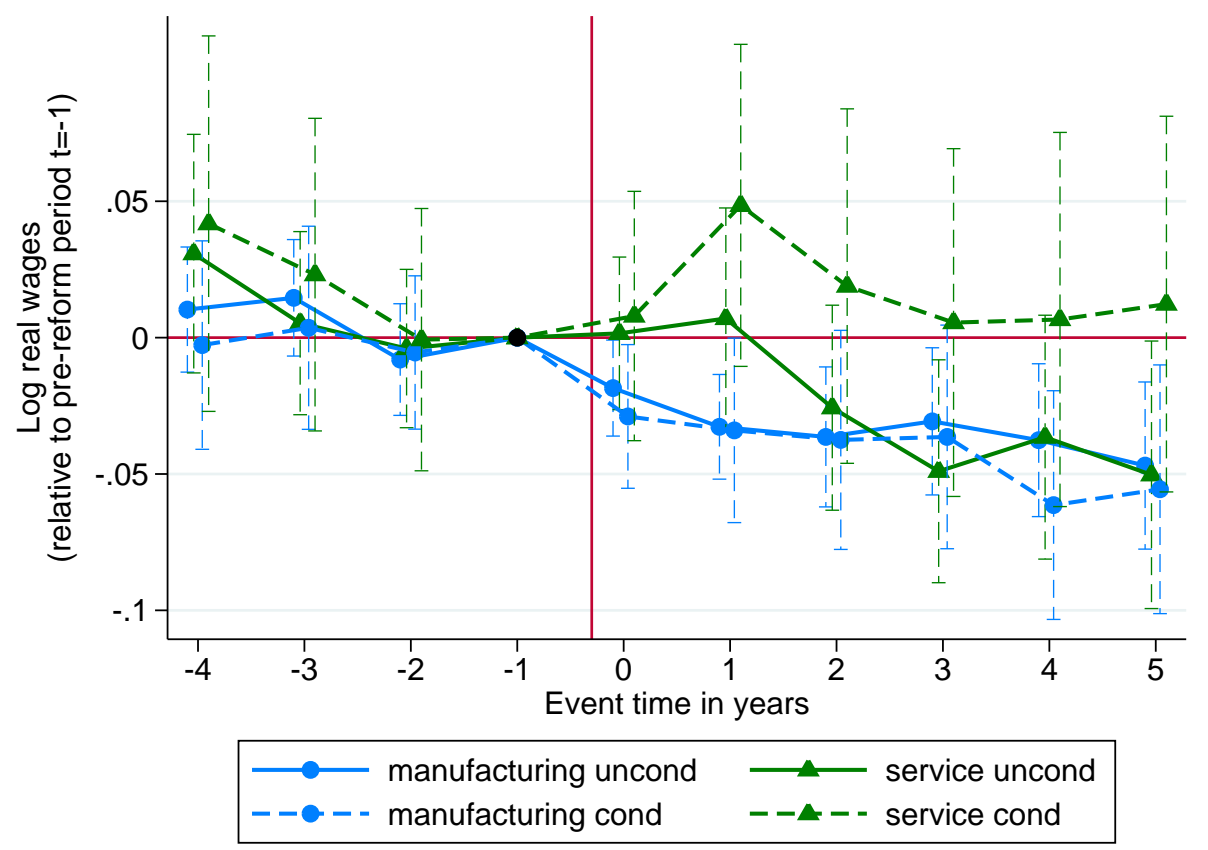

Source: LIAB and Statistical Offices of the Länder. Notes: All curves depict event study estimates $\left(\gamma_{j}, j \in[-4,5]\right)$ and the corresponding $95 \%$ confidence bands obtained by estimating equation (2). The figure presents treatment effects separately for manufacturing and service sector plants (see legend). Heterogeneous effects are estimated by interacting the tax change variables with respective dummies variables indicating the worker/firm type in the period prior to the first data year (1997). The graph shows the evolution of wages in $\log$ points $\left(100 \cdot \gamma_{j}\right)$ before and after a change of the LBT rate. A value of -0.05 implies a wage elasticity with respect to LBT rates of -0.17 (see Section 5.5 ). The tax reform occurred for the treatment group on 1 January in event year $t=0$, as indicated by the vertical red line. Wages are observed on 30 June for each year. The estimation sample includes all liable establishments in non-merged municipalities. All regression models include "state $\times$ year" fixed effects and the following local control variables: log municipal revenues, log municipal population, log county unemployment rate, log county GDP (all lagged by two periods). "Firm-type $\times$ year" fixed effects are also included. For each sector, the dashed lines additionally include log output, investment and employment (each lagged by two periods). Standard errors are clustered at the municipal level. Full regression results are shown in Appendix Table E.8.

Next, we take a closer look at the interactions between collective bargaining and business taxation that might drive the different responses by sector. Results 3 and 4 state that wage effects in the presence of collective bargaining are ambiguous in general. On the one hand, the rent that is shared between workers and firms declines if corporate taxes increase. On the other hand, employment might react to tax changes, which can lead to wage increases depending on the substitutability of the production factors. We group firms into three categories: firms with (i) a sector-level collective bargaining agreement (CBA); (ii) a firm-level agreement; (iii) no bargaining agreement. As the choice of the collective bargaining status may be endogenous, we assign firms to the three categories based on the 1997 information (i.e., 1 year before our wage panel starts).

Our theoretical model predicts wage effects to be stronger for firm-level bargaining 
than for sector-level bargaining - especially if the sector has a presence in many municipalities (cf. Result 4). Panel A of Figure 5 tests this prediction. We find that firms with a firm-level CBA show a much stronger negative wage effect than firms with sector-level bargaining. Nevertheless, we see a negative (yet insignificant) wage response for sector-level firms as well as for no-bargaining firms. In the following we analyze this modest decrease in more detail. As above, we try to recover the direct wage effect by re-estimating the model conditional on employment, investment and output so as to eliminate the indirect wage effects. In line with the theoretical predictions, we do not detect a direct wage effect for non-bargaining firms. Results for firms with CBAs are very similar, which again suggests that direct effects dominate in firms with labor unions.

In the next step, we take into account the fact that not all sector-level bargaining agreements are binding. Sector-level CBAs set a wage floor and firms are allowed to pay above the union wage. We observe whether or not firms pay wages above the bargaining agreement. Moreover, we can distinguish whether firms without a CBA peg their wages to a union contract, which can be rationalized with a fair wage model. Results are depicted in Panel B of Figure 5. In line with our theory, we only find negative wage effects in firms for which the sector-level CBA is not binding. In addition, we find that firm without bargaining tend to respond more strongly if they follow a sector-level agreement and pay wages above the union wage. This can be interpreted as reflecting fairness considerations in the wage setting process. 
Figure 5: Effects on firm wages - by collective bargaining

Panel A: Effects by CBA type

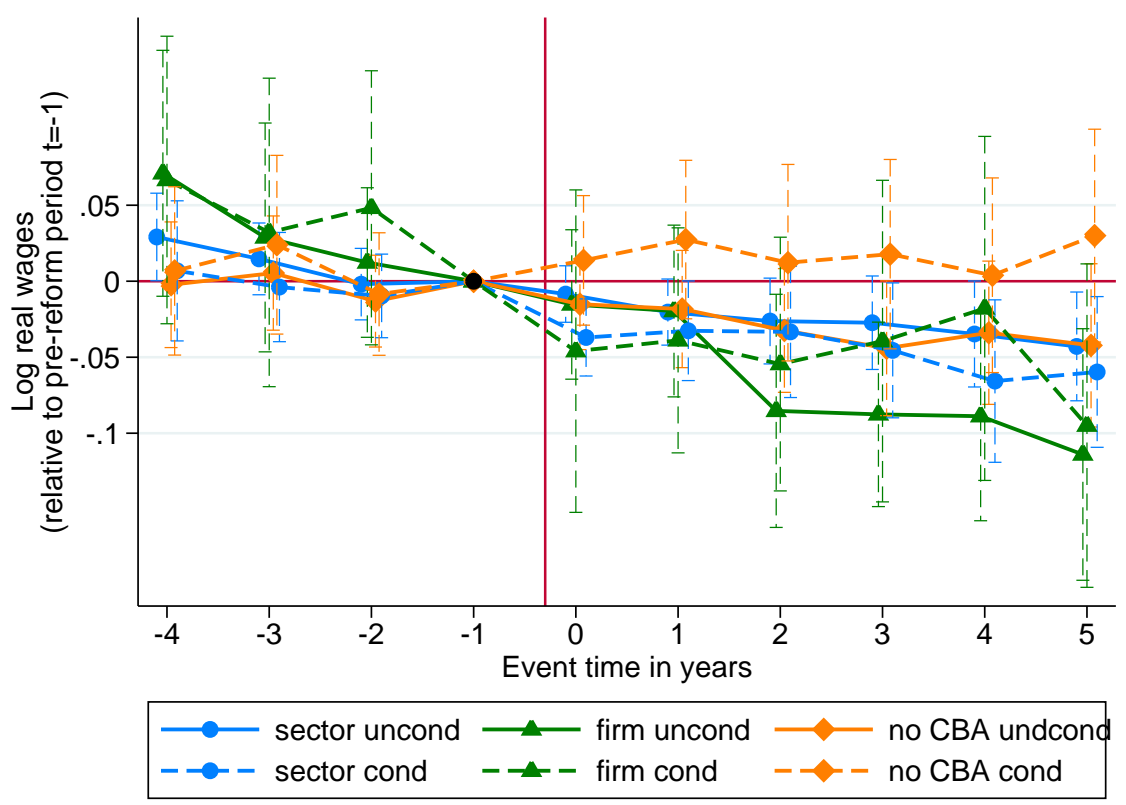

Panel B: Effects by CBA type and whether union contract binding or not

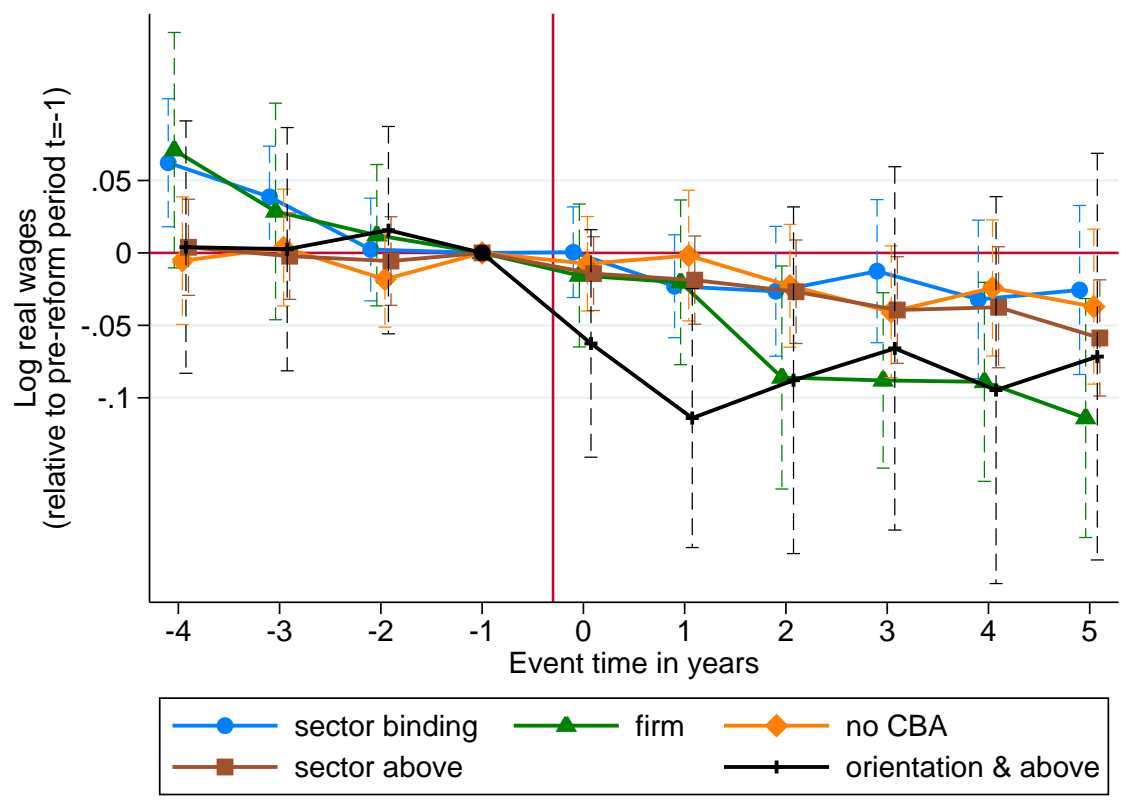

Source: LIAB and Statistical Offices of the Länder. Notes: All curves depict event study estimates $\left(\gamma_{j}, j \in[-4,5]\right)$ and the corresponding $95 \%$ confidence bands obtained by estimating equation (2). The figure presents treatment effects separately for plants with sector-level, firm-level or no collective bargaining agreements in Panel A and whether union contracts are binding or not in Panel B (see legend). Heterogeneous effects are estimated by interacting the tax change variables with respective dummies variables indicating the worker/firm type in the period prior to the first data year (1997). The graph shows the evolution of wages in $\log$ points $\left(100 \cdot \gamma_{j}\right)$ before and after a change of the LBT rate. A value of -0.05 implies a wage elasticity with respect to LBT rates of -0.17 (see Section 5.5). The tax reform occurred for the treatment group on 1 January in event year $t=0$, as indicated by the vertical red line. Wages are observed on 30 June for each year. The estimation sample includes all liable establishments in non-merged municipalities. All regression models include "state $\times$ year" fixed effects and the following local control variables: log municipal revenues, log municipal population, log county unemployment rate, $\log$ county GDP (all lagged by two periods). "Firm-type $\times$ year" fixed effects are also included. In Panel A, the dashed lines additionally include log output, investment and employment (each lagged by two periods). Standard errors are clustered at the municipal level. Full regression results are shown in Appendix Table E.9. 
Theoretical Result 8 indicates that the wage effects of local business taxes are ambiguous if firms operate plants in several jurisdictions. In fact, if we assume just one type of labor, wage responses converges towards zero if the share of employment in the taxed jurisdiction over total firm employment declines. Panel A of Figure 6 demonstrates that we only find a negative effect for single-establishment firms, while establishments in multi-plant firms show no significant wage response. It is possible that this effect is driven by plant size as multi-establishment firms operate larger plants than single-establishment firms. In Panel B of Figure 6, we interact the event study regressors with terciles of value added in $1997^{50}$ and test for differential size effect. We find that the largest plants do not react significantly to changes in the business tax rate. But we do not find significant size differences between single-plant and multi-plant firms. Our evidence thus supports Result 8: formula apportionment can dilute the negative effect of taxes on wages. This finding is also important for state-level corporate taxes in the U.S.

A possible explanation for the zero-wage effect for large firms could be that large plants often belong to large, multinational companies. For these firms, tax-motivated international profit shifting plays a role. As shown in Result 9, we expect wage effects to be smaller in such multinational firms. Another mechanism to reduce the tax base is to shift profits from labor income by, say, increasing wages of family members. This type of adjustment, which may be particularly relevant for small firms, would also mitigate the wage effect of corporate taxes. In view of the strongest effects for small firms depicted in Panel B of Figure 6, we can reject the latter theoretical prediction empirically.

\footnotetext{
${ }^{50}$ We find the same result when we (a) construct the size categories year by year and allow for switching size groups and (b) use number of employees as a measure of firm size
} 
Figure 6: Effects on firm wages - by shifting opportunities

Panel A: Effects of single vs. multi-plant firms

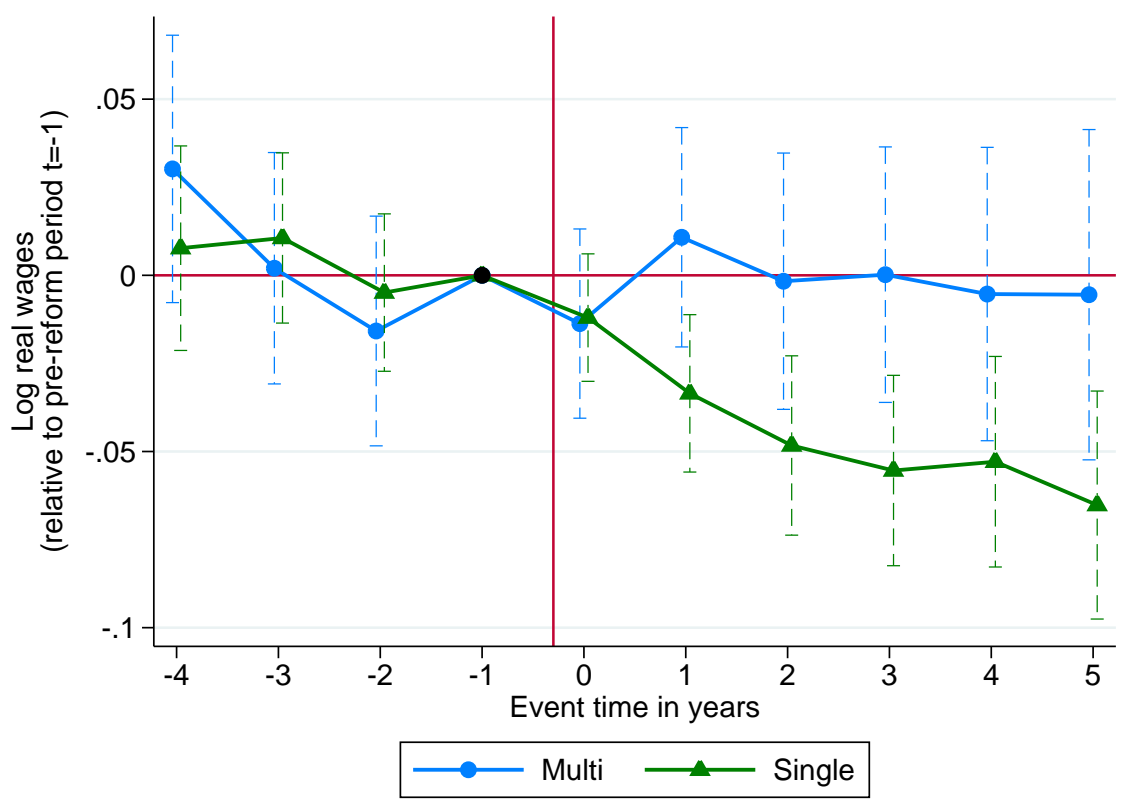

Panel B: Effects by firm size

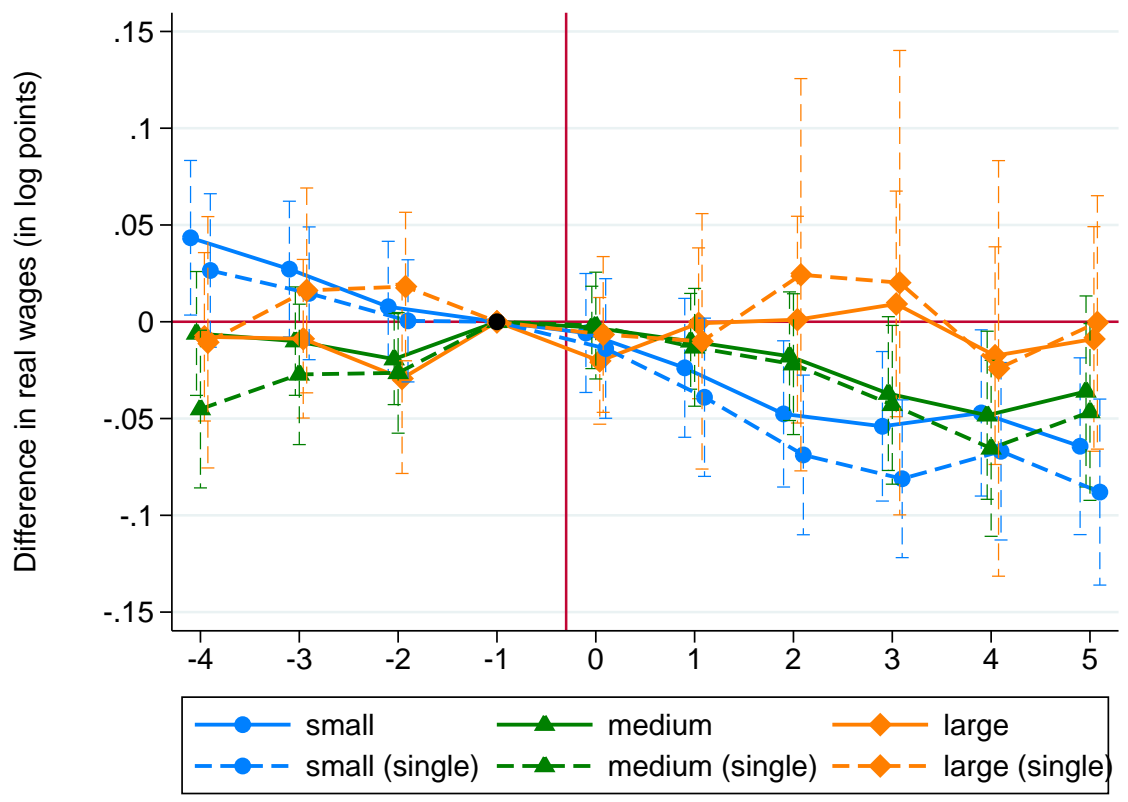

Source: LIAB and Statistical Offices of the Länder. Notes: All curves depict event study estimates $\left(\gamma_{j}, j \in[-4,5]\right)$ and the corresponding $95 \%$ confidence bands obtained by estimating equation (2). The figure presents treatment effects separately for establishments of single-plant and multi-plant firms in Panel A as well as for small, medium and large establishments as defined by terciles of value added in Panel B (for all plants and single-plant firms only) (see legend). Heterogeneous effects are estimated by interacting the tax change variables with respective dummies variables indicating the worker/firm type in the period prior to the first data year (1997). The graph shows the evolution of wages in log points $\left(100 \cdot \gamma_{j}\right)$ before and after a change of the LBT rate. A value of -0.05 implies a wage elasticity with respect to LBT rates of -0.17 (see Section 5.5). The tax reform occurred for the treatment group on 1 January in event year $t=0$, as indicated by the vertical red line. Wages are observed on 30 June for each year. The estimation sample includes all liable establishments in non-merged municipalities. All regression models include "state $\times$ year" fixed effects and the following local control variables: log municipal revenues, log municipal population, log county unemployment rate, log county GDP (all lagged by two periods). "Firm-type $\times$ year" fixed effects are also included. Standard errors are clustered at the municipal level. Full regression results are shown in Appendix Table E.10. 
Last we look at firm profitability. Drawing on responses from a question of selfrated profitability, Figure 7 shows that more profitable firms see larger wage decreases after tax increases. ${ }^{51}$ There are several ways to interpret this result. Theoretically, at least, firms that have made a loss might even benefit from tax cuts, would might explain why we find no effects for the least profitable firms. Moreover, larger wage effects for more profitable firms could also be rationalized by fair wage models (Result 5): if wages depend positively on profits, shocks to profits through higher corporate taxes should affect wages more strongly in more profitable firms.

Figure 7: Effects on firm wages - by profitability

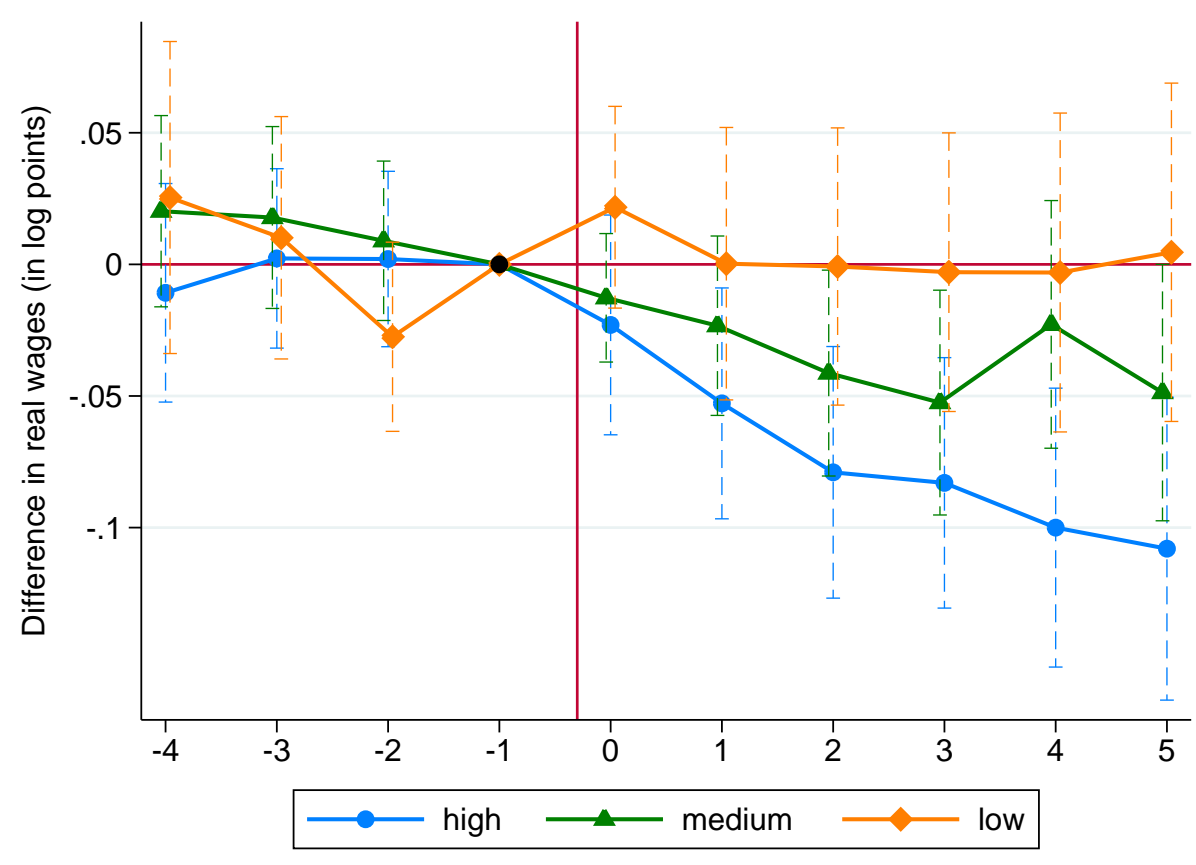

Source: LIAB and Statistical Offices of the Länder. Notes: All curves depict event study estimates $\left(\gamma_{j}, j \in[-4,5]\right)$ and the corresponding $95 \%$ confidence bands obtained by estimating equation (2). The figure presents treatment effects separately for plants by self-rated profitability, measured on a scale from "1 - high" to " 3 - low" (see legend). Heterogeneous effects are estimated by interacting the tax change variables with respective dummies variables indicating the worker/firm type in the period prior to the first data year (1997). The graph shows the evolution of wages in $\log$ points $\left(100 \cdot \gamma_{j}\right)$ before and after a change of the LBT rate. A value of -0.05 implies a wage elasticity with respect to LBT rates of -0.17 (see Section 5.5). The tax reform occurred for the treatment group on 1 January in event year $t=0$, as indicated by the vertical red line. Wages are observed on 30 June for each year. The estimation sample includes all liable, corporate establishments in single-plant firms located in non-merged municipalities. All regression models include "state $\times$ year" fixed effects and the following local control variables: log municipal revenues, log municipal population, log county unemployment rate, log county GDP (all lagged by two periods). "Firm-type $\times$ year" fixed effects are also included. Standard errors are clustered at the municipal level. Full regression results are shown in Appendix Table E.8.

${ }^{51}$ Note that we focus on single-plant firms here. For establishments in multi-plant firms it is not clear whether the self-rated profitability refers to the individual plant or the firm as a whole. Moreover, these multi-establishment firms seem to shift profits in other jurisdictions (see Result 7 and Figure 6) leading to low or no wage responses. 


\subsection{Heterogeneous worker effects}

In this section, we test for worker heterogeneity by estimating model (3) at the individual level. ${ }^{52}$ First, we verify the results obtained from the analysis at firm-level (see Appendix Figures D.4). We then also restrict our estimation sample as above and focus on liable firms in non-merged municipalities to test for heterogeneous worker effects.

In our first test, we look at the effect by skill level. Panel A of Figure 8 shows the results. First, we consider the results when not accounting for wage censoring, that is, when using the social security contribution (SSC) ceiling for censored individuals as the observed wage. The solid lines show that medium-and low-skilled individuals show similar negative wage responses. By contrast, we find no significant negative effect for high-skilled workers. As discussed above, the finding for high-skilled might be biased towards zero as wage responses for individuals above the SSC ceiling are not observed. Accordingly, we re-estimate the model based on the sample of individuals who have never been censored in their wages during the observation period. In this case, we find a very similar wage effect across skill groups, as indicated by the dashed lines.

In Panel B of Figure 8, we differentiate by collar type. The graph shows that the effect is stronger for blue-collar workers. A potential explanation for the difference is that white-collar workers are relatively more mobile and hence see smaller wage responses to tax rate changes.

\footnotetext{
${ }^{52}$ Unlike the analysis at the firm-level, for which we used the median wage as our left-hand-side variable, the observed wage at the individual level might be problematic due to the censoring of the wages at the ceiling for SSC. This might be particularly relevant for high-skilled workers. We address this issue below.
} 
Figure 8: Effects on individual wages - by qualification

Panel A: Effects by skill

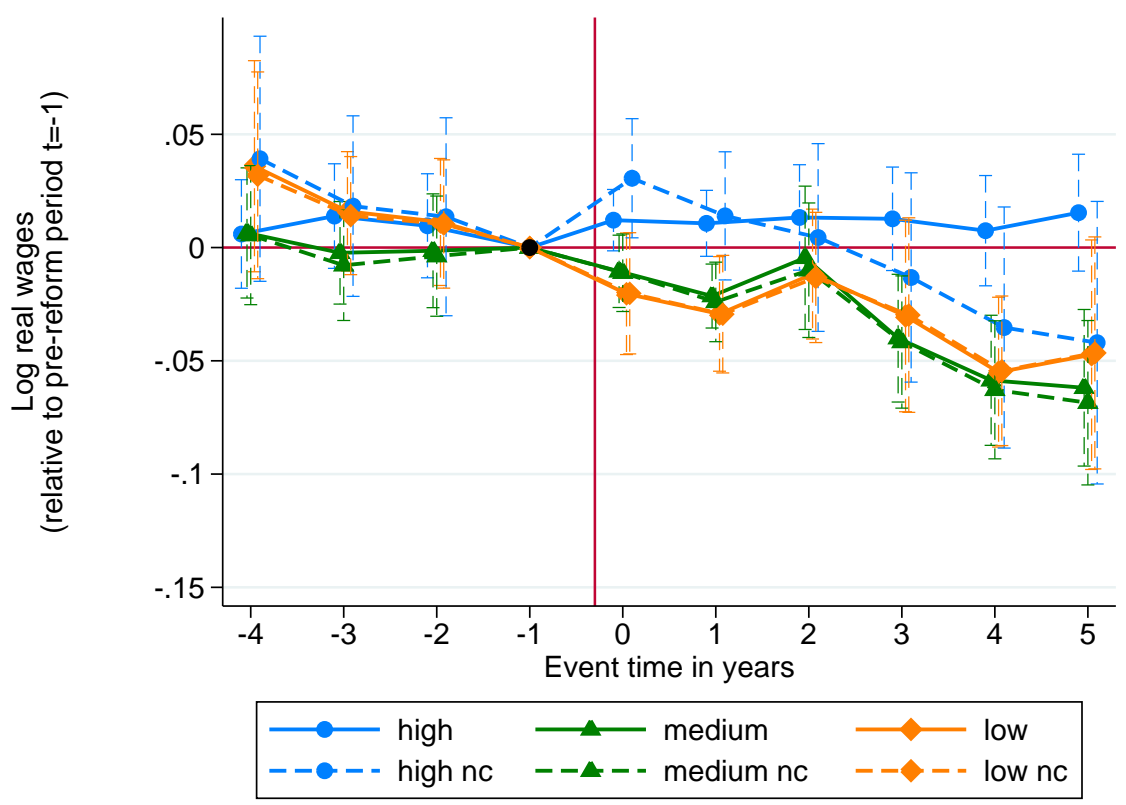

Panel B: Effects by occupation

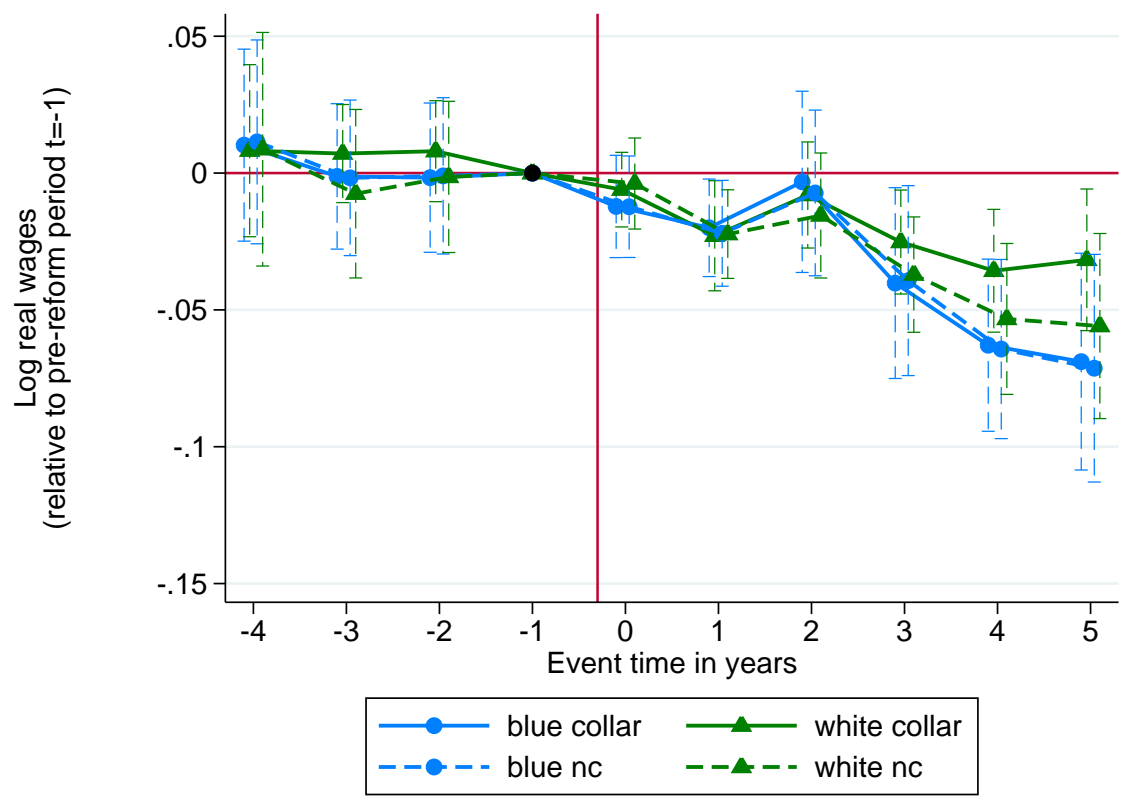

Source: LIAB and Statistical Offices of the Länder. Notes: All curves depict event study estimates $\left(\gamma_{j}, j \in[-4,5]\right)$ and the corresponding $95 \%$ confidence bands obtained by estimating equation (3). The figure presents treatment effects separately for workers by skill in Panel A (for all workers and for only those whose wages were never censored, "nc") and by broad occupation in Panel B (see legend). Heterogeneous effects are estimated by interacting the tax change variables with respective dummies variables indicating the worker/firm type in the period prior to the first data year (1997). The graph shows the evolution of wages in $\log$ points $\left(100 \cdot \gamma_{j}\right)$ before and after a change of the LBT rate. A value of -0.05 implies a wage elasticity with respect to LBT rates of -0.17 (see Section 5.5 ). The tax reform occurred for the treatment group on 1 January in event year $t=0$, as indicated by the vertical red line. Wages are observed on 30 June for each year. The estimation sample includes all liable, corporate establishments in non-merged municipalities. All regression models include "state $\times$ year" fixed effects and the following local control variables: $\log$ municipal revenues, $\log$ municipal population, $\log$ county unemployment rate, log county GDP (all lagged by two periods). "Worker-type $\times$ year" fixed effects are also included. Standard errors are clustered at the municipal level. Full regression results are shown in Appendix Table E.11. 
Last, we differentiate by gender. Figure 9 shows that the effect is stronger for women than for men. This finding could be explained with the higher labor supply elasticities of women (Bargain et al., 2014) in monopsonistic labor markets, as stated by Result 7 of our theory. An alternative explanation would be that women have more bargaining power in individual wage negotiations. Empirical evidence suggests the opposite, however (Card et al., 2015). We also tested for heterogeneous effects between (i) full-time and part-time wages, (ii) for different age groups as well as (iii) across the wage distribution by splitting individuals in wage quintiles based on 1997 wages. However, results were similar between these groups.

Figure 9: Effects on individual wages - by gender

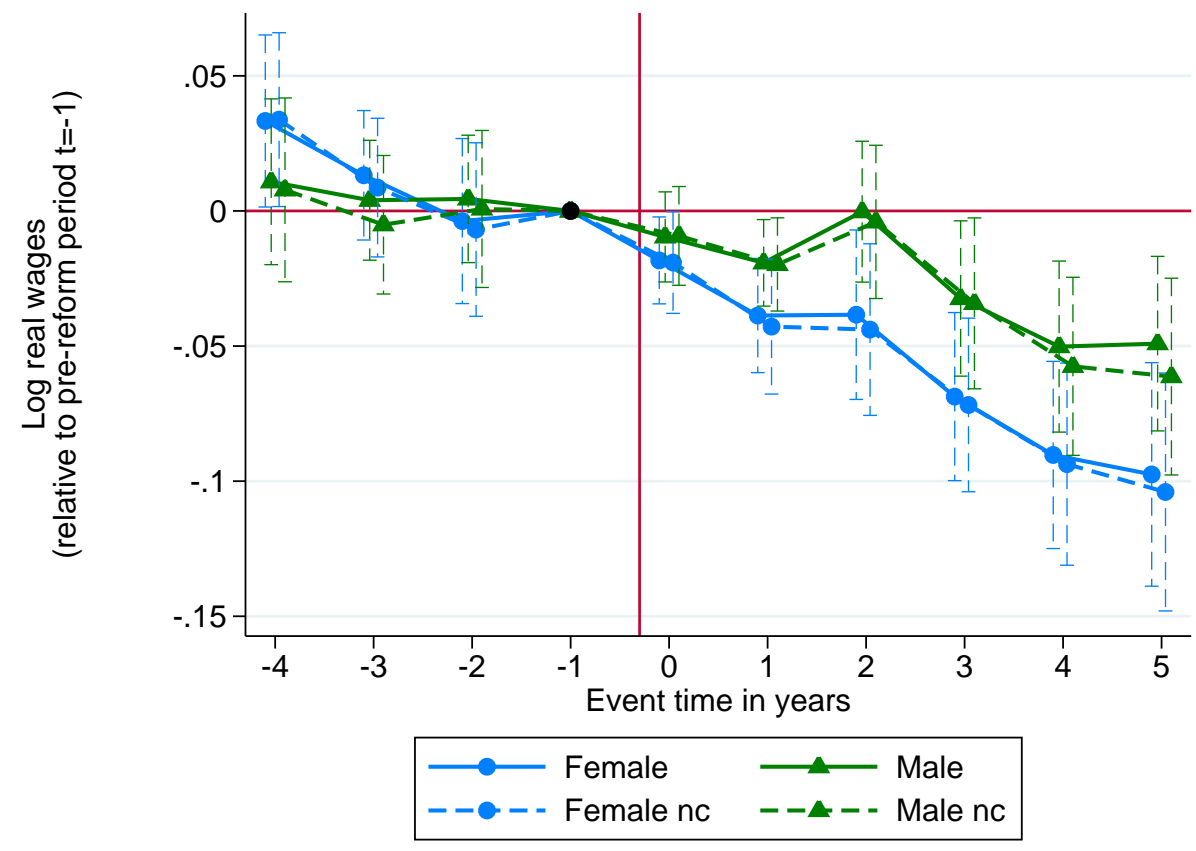

Source: LIAB and Statistical Offices of the Länder. Notes: All curves depict event study estimates $\left(\gamma_{j}, j \in[-4,5]\right)$ and the corresponding $95 \%$ confidence bands obtained by estimating equation (3). The figure presents treatment effects separately for workers by gender (for all workers and for only those whose wages were never censored, "nc") (see legend). Heterogeneous effects are estimated by interacting the tax change variables with respective dummies variables indicating the worker/firm type in the period prior to the first data year (1997). The graph shows the evolution of wages in log points $\left(100 \cdot \gamma_{j}\right)$ before and after a change of the LBT rate. A value of -0.05 implies a wage elasticity with respect to LBT rates of -0.17 (see Section 5.5). The tax reform occurred for the treatment group on 1 January in event year $t=0$, as indicated by the vertical red line. Wages are observed on 30 June for each year. The estimation sample includes all liable, corporate establishments in non-merged municipalities. All regression models include "state $\times$ year" fixed effects and the following local control variables: log municipal revenues, log municipal population, log county unemployment rate, log county GDP (all lagged by two periods). "Worker-type $\times$ year" fixed effects are also included. Standard errors are clustered at the municipal level. Full regression results are shown in Appendix Table E.11. 


\subsection{Measuring the tax incidence}

In this subsection, we calculate what our wage elasticity estimates imply for the incidence of the corporate tax on wages. In order to do this, we need to translate the wage responses into money metrics. We follow Arulampalam et al. (2012) and calculate a measure that describes the wage bill response to a marginal change in the tax bill, $\frac{d(w L)}{d(\tau P)}$. For given production factors, it is straightforward to show that this measure is given by

$$
\frac{d(w L)}{d(\tau P)}=\frac{L d w}{P d \tau+\tau d P}=\frac{L d w}{P d \tau-\tau L d w}=1 /\left(\frac{1}{\eta \frac{w L}{\tau P}}-\tau\right)
$$

where $\eta$ is the wage elasticity with respect to the tax rate. The measure $\frac{d(w L)}{d(\tau P)}$ describes how much of a marginal change in tax liabilities is borne by workers through lower wages. Note that the total tax burden is likely to be higher than tax liabilities due to the marginal excess burden of taxation, $M E B$. In this case, the share of workers in the overall burden of a corporate tax change is given by $\frac{d(w L)}{d(\tau P)} \cdot \frac{1}{(1+M E B)}$.

Table 1 shows our results for the wage effects after five years. Our preferred estimate (liable firms in non-merged municipalities) is equal to -0.00047 , which corresponds to a wage elasticities of -0.142 . This estimates implies that a 1-euro increase in a firm's tax bill leads to a decrease in the wage bill of 56 cents. As we cannot estimate the marginal excess burden with the data at hand, we have to rely on estimates from the literature to quantify the total incidence on labor. If we assume a marginal deadweight loss of corporate taxation of $29 \%$ as suggested by Devereux et al. (2014), $43 \%$ of the total tax burden is borne by workers. This finding is comparable to other studies analyzing the corporate tax incidence on wages (Arulampalam et al., 2012; Liu and Altshuler, 2013; Suárez Serrato and Zidar, 2014). While the former two studies find that the a 1-dollar increase in the tax bill leads to a 50-cent decrease in the wage bill (not accounting for the marginal excess burden), the latter study finds that worker bear 30-35\% of the total tax burden.

Table 1 further reports wage elasticities and money metrics for different samples and firm types. While incidence measures are similar for manufacturing and service sector firms, we find differences with respect to collective bargaining agreements. Our results show that responses in firms with firm-level bargaining are much higher than in firms with sector-level CBAs. In fact, wage responses in firms where bargaining takes place at the sector-level are similar to responses in firms without a CBA, which suggests that business taxes also interact with other wage setting institutions. 
Table 1: Incidence calculations after 5 years

\begin{tabular}{lllll}
\hline Model & Coefficient & Wage elasticity & Euro measure & Incidence \\
& \multicolumn{1}{l}{} & & \\
\hline Liable & $-0.00047^{* * *}$ & $-0.142^{* * *}$ & $-0.56^{* * *}$ & $-0.43^{* * *}$ \\
& $(0.00015)$ & $(0.045)$ & $(0.16)$ & $(0.13)$ \\
Manufacturing & $-0.00047^{* *}$ & $-0.142^{* *}$ & $-0.56^{* *}$ & $-0.43^{* *}$ \\
& $(0.00023)$ & $(0.069)$ & $(0.25)$ & $(0.19)$ \\
Services & -0.00050 & -0.152 & -0.60 & -0.46 \\
& $(0.00035)$ & $(0.106)$ & $(0.38)$ & $(0.29)$ \\
Sector-level CBA & $-0.00043^{* *}$ & $-0.130^{* *}$ & $-0.51^{* * *}$ & $-0.40^{* * *}$ \\
& $(0.00018)$ & $(0.054)$ & $(0.20)$ & $(0.15)$ \\
Firm-level CBA & $-0.00114^{* * *}$ & $-0.344^{* * *}$ & $-1.21^{* * *}$ & $-0.94^{* * *}$ \\
& $(0.00042)$ & $(0.127)$ & $(0.36)$ & $(0.28)$ \\
No CBA & -0.00042 & -0.127 & $-0.51^{*}$ & $-0.39^{*}$ \\
& $(0.00027)$ & $(0.082)$ & $(0.30)$ & $(0.23)$ \\
\hline
\end{tabular}

Source: LIAB and Statistical Offices of the Länder. Notes: The table reports different measures of the effect of local business taxes on wages after five years for different firm types. Coefficients are the estimates of $\gamma_{5}$ of the event study design set up by equation (2). Wage elasticities measure the percent response of wages to a $1 \%$ increase in the LBT rate. The euro measures captures the implied decline in the wage bill for a 1-euro increase in the LBT bill. For this calculation we use a ratio of the tax bill to the wage bill of 0.23 , which is what we observe in the data. The incidence measures the share of the total tax burden that is borne by workers assuming a deadweight burden of corporate taxes of $29 \%$ of the tax revenue (Devereux et al., 2014). Standard errors (in parentheses) are calculated using the Delta method (except for the coefficients). Significance levels are ${ }^{*}<0.10,{ }^{* *}<0.05,{ }^{* * *}<0.01$.

\section{Conclusions}

In this paper, we exploit the institutional setting of the German local business tax to estimate the incidence of corporate tax on wages. Local autonomy in tax rates allows us to treat municipalities as many small open economies. On average $9.5 \%$ of the 10,000 nonmerged municipalities change their local tax rates per year, yielding 18,000 tax reforms that we use for identification. We link administrative information from 1993 to 2012 on the universe of municipalities to administrative linked employer-employee data and estimate the effect of corporate taxation on wages.

We find that a 1-euro increase in the corporate tax bill leads to a 0.56 -euro decrease in the wage bill for given input factors. This suggests that labor bears about $40-50 \%$ of the total tax burden (depending on the marginal excess burden). Estimating heterogeneous firm and worker effects, we test various predictions emerging from our theoretical framework. First, we do not find any effects on firms that are not liable to the LBT. Second, wage responses are more negative for firms under a collective bargaining agreement where rents are shared between firms and workers. Third, for sector-level bargaining firms, wage responses are smaller compared to firm-level bargaining firms and mostly driven by firms 
that pay wages above the collective bargaining contract. Fourth, firms without collective bargaining agreements only show a negative wage response if they follow sector-level union contracts, which could be rationalized with fair wage models. Fifth, wage effects are close to zero for firms which operate in multiple jurisdictions. This can be explained by formula apportionment and profit shifting opportunities across municipalities. Sixth, we find smaller effects for larger plants, which are more likely to be part of a multinational groups, and hence may exploit international profit shifting opportunities leading to smaller wage effects.

Several general lessons can be learned from our analysis. First, we confirm most economists' beliefs and theoretical predictions that labor bares a substantial share of the corporate tax burden. Our estimates suggests that roughly $40 \%$ of the tax burden is passed onto workers. Importantly, this finding is obtained by exploiting variation at the municipal level, which may have implications for the size of the estimate. Compared to changes in national corporate tax rates, two potential differences are worth noting. On the one hand, labor is likely to be more mobile compared with capital at the local level, which attenuates the wage effect. On the other hand, focusing on tax changes at the local level implies that price changes (both of goods and other production factors) are probably much smaller than in the case of national corporate tax changes. This would imply that wage effects of local tax changes are larger.

Second, our theoretical predictions and empirical findings strongly suggests that labor market institutions be considered when assessing the incidence of corporate taxes on wages. If there are rents in the labor market, due, say, to collective bargaining or firms with monopsonistic power, there are direct effects on wages in addition to conventional effects induced by adjustments in production factors. Moreover, national or international profit-shifting possibilities attenuate the negative effect of corporate taxation on wages.

Last, in terms of policy implications, our analysis suggests that it is worth taking distributional effects into account. We find that part of the tax burden is borne by lowskilled workers. While our results do not suggest that high-skilled workers bear a smaller part of the corporate tax burden, the view that the corporate income tax primarily falls on firm owners is rejected by our analysis. At the same time we find that a larger part of the corporate tax is borne by employees capturing rents in the labor market. The fact that employees in competitive segments of labor markets, where wages are lower, bear a smaller part of the corporate tax burden may be seen as a desirable feature of the tax. 


\section{References}

Acemoglu, D. and R. Shimer (1999). Efficient Unemployment Insurance. Journal of Political Economy 107(5), 893-928.

Akerlof, G. A. and J. L. Yellen (1990). The Fair Wage-Effort Hypothesis and Unemployment. The Quarterly Journal of Economics 105(2), 255-283.

Alda, H., S. Bender, and H. Gartner (2005). European Data Watch: The Linked Employer-Employee Dataset Created from the IAB Establishment Panel and the Process-Produced data of the IAB (LIAB). Schmollers Jahrbuch: Journal of Applied Social Science Studies 125(2), 327-336.

Amiti, M. and D. R. Davis (2010). Trade, Firms, and Wages: Theory and Evidence. Review of Economic Studies 79(1), 1-36.

Andrews, M., T. Schank, and R. Upward (2006). Practical fixed-effects estimation methods for the three-way error-components model. Stata Journal 6(4), 461-481.

Angrist, J. D. and J.-S. Pischke (2009). Mostly Harmless Econometrics. Princeton, New Jersey: Princeton University Press.

Arulampalam, W., M. P. Devereux, and G. Maffini (2012). The Direct Incidence of Corporate Income Tax on Wages. European Economc Review 56(6), 1038-1054.

Auerbach, A. J. (2005). Who Bears the Corporate Tax? A Review of What We Know. NBER Working Paper No. 11686.

Ballentine, J. G. (1978). The Incidence of a Corporation Income Tax in a Growing Economy. Journal of Political Economy 86(5), 863-875.

Bargain, O., A. Peichl, and K. Orsini (2014). Comparing Labor Supply Elasticities in Europe and the US: New Results. Journal of Human Resources 49(3), 723-838.

Barth, E. and J. Zweimüller (1995). Relative Wages under Decentralized and Corporatist Bargaining Systems. Scandinavian Journal of Economics 97(3), 369-384.

Bauer, T. K., T. Kasten, and L. Siemers (2012). Business taxation and wages: Evidence from individual panel data. IZA Discussion Paper No. 6717.

Bender, S., A. Haas, and C. Klose (2000). The IAB Employment Subsample 1975-1995. Schmollers Jahrbuch: Journal of Applied Social Science Studies 120(4), 649-662. 
Bertrand, M., E. Duflo, and S. Mullainathan (2004). How Much Should we Trust Difference-in-Difference Estimates? Quarterly Journal of Economics 119(1), 249-275.

Bird, R. M. (2003). A new look at local business taxes. Tax Notes International 30, 695-711.

Boeri, T. (2014). Two-Tier Bargaining. IZA Discussion Paper No. 8358.

Bradford, D. F. (1978). Factor prices may be constant but factor returns are not. Economics Letters 1(3), 199-203.

Büttner, T. (2003). Tax Base Effects and Fiscal Externalities of Local Capital Taxation: Evidence from a Panel of German Jurisdictions. Journal of Urban Economics 54(1), $110-128$.

Card, D., A. R. Cardoso, and P. Kline (2015). Bargaining, Sorting, and the Gender Wage Gap: Quantifying the Impact of Firms on the Relative Pay of Women. The Quarterly Journal of Economics doi: 10.1093/qje/qjv038.

Card, D., J. Heining, and P. Kline (2013). Workplace heterogeneity and the rise of west german wage inequality. The Quarterly Journal of Economics.

Castanheira, M., G. Nicodème, and P. Profeta (2012). On the political economics of tax reforms: survey and empirical assessment. International Tax and Public Finance 19, 598-624.

Desai, M. A., C. F. Foley, and J. R. Hines (2007). Labor and Capital Shares of the Corporate Tax Burden: International Evidence. mimeo, presented at the International Tax Policy Forum and Urban-Brookings Tax Policy Center conference on Who Pays the Corporate Tax in an Open Economy?, 18 December, 2007.

Devereux, M., L. Liu, and S. Loretz (2014). The Elasticity of Corporate Taxable Income: New Evidence from UK Tax Records. American Economic Journal: Economic Policy 6(2), 19-53.

Diamond, P. A. and J. Mirrlees (1971). Optimal Taxation and Public Production. American Economic Review 61, 8-27 and 261-278.

Du Caju, P., E. Gautier, D. Momferatou, and M. Ward-Warmedinger (2008). Institutional features of wage bargaining in 23 european countries, the us and japan,. ECB Working Paper Series No 974. 
Dustmann, C., B. Fitzenberger, U. Schönberg, and A. Spitz-Oehner (2014). From sick man of europe to economic superstar: Germany's resurgent economy. Journal of Economic Perspectives 28(1), 167-188.

Dustmann, C., J. Ludsteck, and U. Schoenberg (2009). Revisiting the german wage structure. Quarterly Journal of Economics 124(2), 843-881.

Dwenger, N., P. Rattenhuber, and V. Steiner (2011). Sharing the burden: Empirical evidence of corporate tax incidence. Preprint of the Max Planck Institute for Tax Law and Public Finance 2011-14.

Egger, H. and U. Kreickemeier (2012). Fairness, trade, and inequality. Journal of International Economics 86(2), 184-196.

Ellguth, P., H.-D. Gerner, and J. Stegmaier (2012). Wage Bargaining in Germany - the Role of Works Councils and Opening Clauses. IAB Discussion Paper 05/2012.

Feldstein, M. (1974). Incidence of a Capital Income Tax in a Growing Economy with Variable Savings Rates. The Review of Economic Studies 41(4), 505-513.

Felix, R. A. (2007). Passing the Burden: Corporate Tax Incidence in Open Economies. Federal Reserve Bank of Kansas City Regional Research Working Paper 07-01.

Felix, R. A. and J. R. Hines (2009). Corporate Taxes and Union Wages in the United States. NBER Working Paper No. 15263.

Foremny, D. and N. Riedel (2014). Business Taxes and the Electoral Cycle. Journal of Public Economics.

Fuchs, V. R., A. B. Krueger, and J. M. Poterba (1998). Economists' views about parameters, values, and policies: Survey results in labor and public economics. Journal of Economic Literature 36(3), 1387-1425.

Fuest, C., A. Peichl, and S. Siegloch (2011). Do Employees Bear the Burden of Corporate Taxation? A Micro Level Approach Using Linked Employer-Employee Data. Presented at the 67th Annual Congress of the International Institute of Public Finance in Ann Arbor.

Fuest, C., A. Peichl, and S. Siegloch (2013). Do Higher Corporate Taxes Reduce Wages? Micro Evidence from Germany. IZA Discussion Paper No. 7390.

Gravelle, J. C. (2013). Corporate Tax Incidence: Review of General Equilibirum Estimates and Analysis. National Tax Journal 66(1), 185-214. 
Harberger, A. C. (1962). The incidence of the corporation income tax. Journal of Political Economy 70, 215-240.

Harberger, A. C. (1995). The ABCs of Corporate Tax Incidence: Insights into the OpenEconomy Case. In Tax Policy and Economic Growth: Proceedings of a Symposium sponsored by the American Council for Capital Formation, pp. 51-73. Washington: ACCF Center for Policy Research.

Harberger, A. C. (2006). Corporate Tax Incidence: Reflections on What Is Known, Unknonw and Unknowable. In J. W. Diamond and G. R. Zodrow (Eds.), Fundamental Tax Reforms: Issues, Choices, and Implications, pp. 283-308. Cambridge, MA: MIT Press.

Hassett, K. A. and A. Mathur (2006). Taxes and Wages. AEI Working Paper No. 128.

Janeba, E. and S. Osterloh (2012). Tax and the city: A theory of local tax competition and evidence for Germany. ZEW Discussion Papers No. 12-005.

Kawano, L. and J. Slemrod (2012). The Effect of Tax Rates and Tax Bases on Corporate Tax Revenues: Estimates with New Measures of the Corporate Tax Base. NBER Working Papers 18440.

Kölling, A. (2000). The IAB-Establishment Panel. Schmollers Jahrbuch: Journal of Applied Social Science Studies 120(2), 291-300.

Kotlikoff, L. J. and L. H. Summers (1987). Tax Incidence. In A. J. Auerbach and M. Feldstein (Eds.), Handbook of Public Economics, Volume 2, pp. 1043-1092. Amsterdam: Elsevier.

Liu, L. and R. Altshuler (2013). Measuring the burden of the corporate income tax under imperfect competition. National Tax Journal 66(1), 215-237.

McDonald, I. M. and R. E. Solow (1981). Wage Bargaining and Employment. The America Economic Review 71(5), 896-908.

NCSL (2009). State, federal and local taxes. http://www.ncsl.org/documents/fiscal/ statefederalandlocaltaxes.pdf.

OECD (2015). Tax on corporate profits (indicator). doi: 10.1787/d30cc412-en.

Oswald, A. J. (1993). Efficient contracts are on the labour demand curve: Theory and facts. Labour Economics 1(1), 85-113. 
Ratti, R. A. and P. Shome (1977). On a General Equilibrium Model of the Incidence of the Corporation Tax under Uncertainty. Journal of Public Economics 8(2), 233-238.

Rogerson, R., R. Shimer, and R. Wright (2005). Search-Theoretic Models of the Labor Market: A Survey. Journal of Economic Literature 43(4), 959-988.

Sandler, D. H. and R. Sandler (2014). Multiple event studies in public finance and labor economics: A simulation study with applications. Journal of Economic and Social Measurement 39, 31-57.

Shapiro, C. and J. Stiglitz (1984). Equilibrium unemployment as a worker discipline device. The American Economic Review 74, 433-444.

Shoven, J. B. (1976). The Incidence and Efficiency Effects of Taxes on Income from Capital. Journal of Political Economy 84(6), 1261-1283.

Siegloch, S. (2013). Employment Effects of Local Corporate Taxes. Mimeo.

Solow, R. M. (1979). Another possible source of wage stickiness. Journal of Macroeconomics 1(1), 79-82.

Spengel, C., D. Endres, K. Finke, and J. H. Heckemeyer (2014). Effective Tax Levels using the Devereux/Griffith Methodology. Project for the EU Commission TAXUD/2013/CC/120 Final Report.

Suárez Serrato, J. C. and O. Zidar (2014). Who Benefits from State Corporate Tax Cuts? A Local Labor Markets Approach with Heterogeneous Firms. NBER Working Paper 20289. 


\section{Appendices for online publication only}

\section{A Theoretical derivations}

In this appendix, we discuss the implications of various wage setting models for the impact of corporate tax changes on wages. We do so by using the model introduced in the main text, which we discuss here in greater detail. As will be explained further below, the model will be varied slightly to incorporate different assumptions about wage setting and two aspects of the tax system relating to formula apportionment and income shifting.

Consider an economy which consists of $n$ jurisdictions. There are firms in the economy. To ease notation we normalize the number of firms per jurisdiction to unity. Firms use the following factors of production: capital $(K)$ and labor of two skill levels. Labor of skill type $k, k=h, l$, is denoted by $L^{k}$. We will consider different production technologies. In the base version of the model we consider a production function $F\left(K, L^{h}, L^{l}\right)$, which is assumed to have the usual neoclassical properties and to exhibit declining returns to scale. One interpretation is that there is an implicit fourth factor which may be interpreted as a location specific rent. While capital and both types of labor are mobile across municipal borders, firms are immobile, due to the location specific rent.

The after-tax profit of a firm $i$ located in jurisdiction $j, j=1 \ldots n$, is given by

$$
P_{i j}=p_{i} F_{i}\left(K_{i}, L_{i}^{h}, L_{i}^{l}\right)\left(1-\tau_{j}\right)-\sum_{k} w_{i}^{k} L_{i}^{k}\left(1-\phi \tau_{j}\right)-\left(1-\alpha \tau_{j}\right) r K_{i}
$$

where $p_{i}$ is the output price, $w_{i}^{k}$ is the wage for labor of skill type $k, \tau_{j}$ is the corporate income tax rate of jurisdiction $j$ and $r$ is the non-tax cost of capital. The variables $\phi, \alpha$ are tax base parameters representing the shares of the wage and capital costs, which can be deducted from the tax base. These parameters are the same in all jurisdictions. We assume $0 \leq \phi \leq 1,0 \leq \alpha \leq 1$. Since there is only one firm per jurisdiction, we can drop the subscript $j$. We also normalize the output price to unity.

In some variants of the model labor markets may not be clear. In these cases, we assume that unemployed workers of skill type $k$ receive unemployment benefits denoted by $\bar{w}^{k}$.

\section{A.1 Competitive labor market}

Assume that input and output markets are perfectly competitive, so that factor prices will adjust to equate demand and supply. Factor demand functions are given by the firm's first order conditions 


$$
\frac{\partial F_{i}\left(K_{i}, L_{i}^{h}, L_{i}^{l}\right)}{\partial K_{i}}=\frac{\left(1-\alpha \tau_{i}\right)}{\left(1-\tau_{i}\right)} r
$$

and

$$
\frac{\partial F_{i}\left(K_{i}, L_{i}^{h}, L_{i}^{l}\right)}{\partial L_{i}^{k}}=\frac{\left(1-\phi \tau_{i}\right)}{\left(1-\tau_{i}\right)} w_{i}^{k} . \quad k=h, l .
$$

Equations (5) and (6) implicitly define the factor demand functions

$$
K_{i}^{D}\left(W_{i}^{h}, W_{i}^{l}, R_{i}\right) \quad \text { and } \quad L_{i}^{k D}\left(W_{i}^{h}, W_{i}^{l}, R_{i}\right) \quad k=h, l
$$

where $W_{i}^{k}=w_{i}^{k} \frac{1-\phi \tau_{i}}{1-\tau_{i}}, k=h, l$ and $R_{i}=r \frac{1-\alpha \tau_{i}}{1-\tau_{i}}$ is the tax inclusive cost of labor of type $k$ and capital, respectively. While the interest rate $r$ is assumed to be independent of capital demand in jurisdiction $j$, wage rates are determined by equating labor demand and labor supply, where the latter is given by the function $L^{k S}\left(w^{k}\right), k=h, l$. Standard comparative static analysis of the labor market equilibrium conditions $L_{i}^{k D}\left(W_{i}^{h}, W_{i}^{l}, R_{i}\right)=$ $L^{k S}\left(w^{k}\right), k=h, l$ yields expressions for the impact of a tax rate change on the skill-specific wage. Let us consider the effect on wages of skill type $h$ :

$$
\begin{aligned}
\frac{d w_{i}^{h}}{d \tau_{i}} & =\frac{L_{i}^{h D} L_{i}^{l D}}{\varphi}\left(\left(\varepsilon_{l l}+\varepsilon_{l h}\right) \frac{1-\phi}{\left(1-\tau_{i}\right)\left(1-\phi \tau_{i}\right)}+\varepsilon_{l R} \frac{1-\alpha}{(1-\alpha)\left(1-\alpha \tau_{i}\right)}\right)\left(\varepsilon_{h h} \frac{1}{w_{i}^{h}}\right) \\
& -\frac{L_{i}^{h D} L_{i}^{l D}}{\varphi}\left(\left(\varepsilon_{h h}+\varepsilon_{h l}\right) \frac{1-\phi}{\left(1-\tau_{i}\right)\left(1-\phi \tau_{i}\right)}+\varepsilon_{h R} \frac{1-\alpha}{(1-\alpha)\left(1-\alpha \tau_{i}\right)}\right)\left(\left(\varepsilon_{l l}-\mu_{l}\right) \frac{1}{w_{i}^{h}}\right)
\end{aligned}
$$

where $\varphi$ is a positive parameter (the determinant of the matrix of coefficients). Parameter $\varepsilon_{s t}$ is the labor demand elasticity of skill group $s$ with respect to wage changes of skill type $t$ and is defined as $\varepsilon_{s t}=\frac{\partial L_{i}^{s D}\left(W_{i}^{h}, W_{i}^{l}, R_{i}\right)}{\partial w_{i}^{t}} \frac{W_{i}^{t}}{L_{i}^{s D}\left(W_{i}^{h}, W_{i}^{l}, R_{i}\right)}, s, t=h, l$. The labor supply elasticity of skill type $k$ is given by $\mu_{k}=\frac{\partial L_{i}^{k S}\left(w^{k}\right)}{\partial w^{k}} \frac{w^{k}}{L_{i}^{k S}\left(w^{k}\right)}, k=h, l$.

Equation (7) shows that, in general, the impact of a tax change on the wage depends on demand and supply elasticities in the labor markets. However, if the corporate tax is a cash flow tax and all costs are perfectly deductible $(\phi=\alpha=1)$, a change in the corporate tax rate will be neutral for factor demand and, hence, will leave wages unchanged. As a result, the corporate tax is a lump sum tax and the tax burden falls entirely on profits:

$$
\frac{\partial P_{i}}{\partial \tau_{i}}=-\left[F_{i}\left(K_{i}, L_{i}^{1}, L_{i}^{2}\right)-\phi \sum_{k=1}^{2} w_{i}^{k} L_{i}^{k}-\alpha r K_{i}\right]<0, \frac{\partial w_{i}^{k}}{\partial \tau_{i}}=0 \quad k=1,2 .
$$

This may be stated as

Result 1: Competitive labor markets: The impact of a tax change on wages depends on the demand and supply elasticities in the labor market. If all costs are perfectly 
deductible, the burden of the corporate income tax is fully borne by firm owners. Then a tax rate change does not affect the wage rate.

\section{A.2 Corporate tax incidence with wage bargaining}

\section{A.2.1 Individual wage bargaining}

We now assume that wages are determined by bargaining between firms and individual workers. The output a worker of type $k$ generates in firm $i$ is given by $Q_{i}^{k}\left(K_{i}^{k}\right)$ and the additional profit the firm earns is $Q_{i}^{k}\left(K_{i}^{k}\right)\left(1-\tau_{i}\right)-w_{i}^{k}\left(1-\phi \tau_{i}\right)-\left(1-\alpha \tau_{i}\right) r K_{i}^{k}$. The variable $K_{i}^{k}$ is the capital the firm invests to equip the worker. The outcome of the bargaining process is given by

$$
w_{i}^{k *}=\arg \max _{w_{i}^{k}} \Omega_{i}
$$

where

$$
\Omega_{i}=\beta_{i}^{k} \ln \left(w_{i}^{k}-\bar{w}^{k}\right)+\left(1-\beta_{i}^{k}\right) \ln P_{i} .
$$

The variable $\beta_{i}^{k} \in(0,1)$ stands for the relative bargaining power of the employee. The first order conditions of the bargaining problem yield

$$
w_{i}^{k *}=\left(1-\beta_{i}^{k}\right) \bar{w}^{k}+\beta_{i}^{k} \frac{Q_{i}^{k}\left(K_{i}^{k}\right)\left(1-\tau_{i}\right)-\left(1-\alpha \tau_{i}\right) r K_{i}^{k}}{\left(1-\phi \tau_{i}\right)} .
$$

The effect of a change in the corporate tax rate on the wage is

$$
\frac{\partial w_{i}^{k *}}{\partial \tau_{i}}=-\beta_{i}^{k} \frac{\left(Q_{i}^{k}\left(K_{i}^{k}\right)-r K_{i}^{k}\right)(1-\phi)+(1-\alpha) r K_{i}^{k}}{\left(1-\phi \tau_{i}\right)^{2}} \leq 0 .
$$

A higher corporate tax reduces the wage unless both wage and capital costs are fully deductible. This may be stated as

Result 2: Individual wage bargaining: If wage or capital costs are less than fully deductible, an increase (decline) in the local corporate tax rate reduces (increases) the wage. The effect increases with the relative bargaining power of the employee.

\section{A.2.2 Collective wage bargaining}

Assume that workers are represented by trade unions. We consider two cases: The first case is firm-level bargaining, where firm-level unions bargain with individual firms. The second case is sector-level bargaining, where sector-level unions bargain with sector-level employer organizations. 
Firm-level bargaining. Denote the wage for a worker of skill type $k$ employed by a firm located in jurisdiction $i$ by $w_{i}^{k}=\bar{w}_{i}^{k}+s_{i}^{k}$, where $s_{i}^{k}$ is the wage premium generated by bargaining at the firm-level. The bargaining model we use for the firm-level is a standard efficient bargaining model (McDonald and Solow, 1981), where unions and firms bargain over the wage premium, $s_{i}^{k}$, and employment $L_{i}^{k}$. Each skill type is represented by one trade union and each firm negotiates with the two unions simultaneously (Barth and Zweimüller, 1995). The objective function of the trade union representing the workers of skill type $k$ in firm $i$ is given by

$$
Z_{i}^{k}=L_{i}^{k}\left(w_{i}^{k}-\bar{w}^{k}\right)=L_{i}^{k} s_{i}^{k}
$$

In the case of disagreement, the rent of the union $Z_{i}^{k}$ and the firm's profit $P_{i}$ are equal to zero. After wages and employment levels are determined, firms set $K_{i}$ to maximize profits:

$$
\frac{\partial F\left(K_{i}, L_{i}^{h}, L_{i}^{l}\right)}{\partial K_{i}}=R_{i}
$$

where $R_{i}$ denotes the cost of capital:

$$
R_{i}=r \frac{\left(1-\alpha \tau_{i}\right)}{\left(1-\tau_{i}\right)}
$$

The outcome of the bargaining process is given by

$$
s_{i}^{k *}, L_{i}^{k *}=\arg \max _{s_{i}^{k}, L_{i}^{k}} \Omega_{i}^{k}
$$

where

$$
\Omega_{i}^{k}=\beta_{i}^{k} \ln Z_{i}^{k}+\left(1-\beta_{i}^{k}\right) \ln P_{i}
$$

The variable $\beta_{i}^{k} \in(0,1)$ stands for relative bargaining power of the skill type $k$ union in firm $i$. The first order conditions of the bargaining problem yield

$$
s_{i}^{k *}=\frac{\left(1-\beta_{i}^{j}\right) \beta_{i}^{k}}{\left(1-\beta_{i}^{k} \beta_{i}^{j}\right)} \frac{\Pi_{i}}{L_{i}^{k}\left(1-\phi \tau_{i}\right)} \quad k, j=h, l, \quad k \neq j
$$

where

$$
\Pi_{i}=F\left(K_{i}, L_{i}^{h}, L_{i}^{l}\right)\left(1-\tau_{i}\right)-\sum_{k} \bar{w}^{k} L_{i}^{k}\left(1-\phi \tau_{i}\right)-\left(1-\alpha \tau_{i}\right) r K_{i}
$$


For employment we find

$$
\frac{\partial F\left(K_{i}, L_{i}^{h}, L_{i}^{l}\right)}{\partial L_{i}^{k}}=\frac{\left(1-\phi \tau_{i}\right) \bar{w}^{k}}{\left(1-\tau_{i}\right)} \quad k=h, l .
$$

The wage premium $s_{i}^{k *}$ is equal to a share of the surplus per employee generated by the firm. The size of this share is increasing in the relative bargaining power of the skill group and decreasing in the bargaining power of the other group of employees. Employment is set so that the marginal productivity of labor is equal to the skill specific reservation wage, corrected for a term reflecting tax deductibility of labor costs. Differentiating (11) yields

$$
\frac{d s_{i}^{k *}}{d \tau_{i}} L_{i}^{k}+s_{i}^{k *} \frac{d L_{i}^{k}}{d \tau_{i}}=-\beta_{0}\left(\left[F\left(K_{i}, L_{i}^{h}, L_{i}^{l}\right)-r K_{i}\right](1-\phi)+(1-\alpha) r K_{i}\right) \leq 0
$$

where

$$
\beta_{0}=\frac{\left(1-\beta_{i}^{j}\right) \beta_{i}^{k}}{\left(1-\beta_{i}^{k} \beta_{i}^{j}\right)\left(1-\phi \tau_{i}\right)^{2}}>0 .
$$

The left-hand side of (13) is equal to the change in the rent accruing to the workers of skill type $k$ employed by firm $i$. This rent unambiguously declines as a consequence of the tax change. Whether the wage rate declines depends on how employment changes in response to the tax change. Equations (10) and (12) implicitly define the factor demand functions $K_{i}\left(\bar{w}^{k}, \bar{w}^{j}, \tau_{i}, ..\right), L_{i}^{k}\left(\bar{w}^{k}, \bar{w}^{j}, \tau_{i}, ..\right)$. Standard comparative static analysis shows that the impact of a tax change on demand for labor of type $k$ may be positive or negative, depending on whether the different production factors are complements or substitutes. The effect on wages is therefore also ambiguous.

This may be summarized as:

Result 3: Firm-level bargaining: If either wage costs or capital costs are less than fully deductible, an increase (decline) in the local corporate tax rate reduces (increases) the rent of each skill group. For given levels of employment the wage rate declines (increases) in response to an increase (decrease) in taxes ('direct effect' of a corporate tax change on wages).

Sector-level bargaining. We now assume that bargaining takes place at the sectorlevel. To ease notation we normalize the number of sectors in the unionized part of the labor market to unity. This implies that there are $n$ firms in the sector. An employer organization bargains with sector-level unions over the sector wide wage. We continue to assume that each skill group is represented by its own trade union. The employer organization has the objective of maximizing aggregate profits of the firms in the sector. 
Following the seniority model proposed by Oswald (1993), we assume that each union wishes to maximize the premium over the reservation wage for the skill group it represents, which is given by $v^{k}=w^{k}-\bar{w}^{k}$. For given wages, firms set profit maximizing employment. The outcome of the sector-level bargaining process is given by

$$
v^{k *}=\arg \max _{p^{k}} \Omega_{i}^{S k}
$$

where

$$
\Omega_{i}^{S k}=\gamma^{k} \ln v^{k}+\left(1-\gamma^{k}\right) \ln \sum_{i=1}^{m} P_{i}
$$

The variable $\gamma^{k} \in(0,1)$ stands for the relative bargaining power of the sector-level skill type $k$ union. Rearranging the first order condition of the bargaining problem yields

$$
v^{k *}=\gamma_{0} \frac{\sum_{i=1}^{n} \Pi_{i}}{\sum_{i=1}^{n} L_{i}^{k}\left(1-\phi \tau_{i}\right)} \quad k, j=h, l, \quad k \neq j
$$

where

$$
\gamma_{0}=\frac{\left(1-\gamma^{j}\right) \gamma^{k}}{\left(1-\gamma^{j} \gamma^{k}\right)}>0
$$

The sector wide wage premium is equal to a share of the average surplus per worker generated by the firms in the sector. Employment and investment decisions are now given by

$$
\frac{\partial F\left(K_{i}, L_{i}^{h}, L_{i}^{l}\right)}{\partial L_{i}^{k}}=\frac{\left(1-\phi \tau_{i}\right) w^{k}}{\left(1-\tau_{i}\right)} \quad k=h, l
$$

and

$$
\frac{\partial F\left(K_{i}, L_{i}^{h}, L_{i}^{l}\right)}{\partial K_{i}}=R_{i}
$$

How does a corporate tax change in jurisdiction $m, m \in(1, \ldots, n)$, affect $v^{k *}$ ? Total differentiation of equation (14) yields 


$$
d v^{k *}=\gamma_{0} \frac{\left[L_{m}^{k} \phi d \tau_{m}-\sum_{i=1}^{n} d L_{i}^{k}\left(1-\phi \tau_{i}\right)\right] \sum_{i=1}^{n} \Pi_{i}+\sum_{i=1}^{n} d \Pi_{i} \sum_{i=1}^{n} L_{i}^{k}\left(1-\phi \tau_{i}\right)}{\left[\sum_{i=1}^{n} L_{i}^{k}\left(1-\phi \tau_{i}\right)\right]^{2}} \quad k, j=h, l, \quad k \neq j
$$

where

$$
\begin{aligned}
\sum_{i=1}^{n} d \Pi_{i}= & -\left[F\left(K_{m}, L_{m}^{h}, L_{m}^{l}\right)-\sum_{k} \bar{w}^{k} L_{i}^{k} \phi-\alpha r K_{i}\right] d \tau_{m} \\
& +\left(v^{h *} \sum_{i=1}^{n} d L_{i}^{h}\left(1-\phi \tau_{i}\right)+v^{l *} \sum_{i=1}^{n} d L_{i}^{l}\left(1-\phi \tau_{i}\right)\right) .
\end{aligned}
$$

In general, the impact of a tax change on the wage is ambiguous.

The wage effect converges to zero if the firm in the jurisdiction where the tax change occurs is small, relative to the sector as a whole. The conditions for the wage effect to be negligible $d v^{k *} \rightarrow 0$, which implies $d L_{i}^{k}=0$ for all $i \neq m, k=h, l$ follow from (16) and are given by

$$
\frac{\left[L_{m}^{k} \phi-\frac{\partial L_{m}^{k}}{\partial \tau_{m}\left(1-\phi \tau_{m}\right)}\right]}{\sum_{i=1}^{n} L_{i}^{k}\left(1-\phi \tau_{i}\right)} \rightarrow 0, \frac{F\left(K_{m}, L_{m}^{h}, L_{m}^{l}\right)-\sum_{k} w^{k} L_{m}^{k} \phi-\alpha r K_{m}}{\sum_{i=1}^{n} L_{i}^{k}\left(1-\phi \tau_{i}\right)} \rightarrow 0 .
$$

In other words, the effect is negligible if employment (including the tax induced change in employment) as well as the tax base in jurisdiction $m$ are small, relative to the number of employees in the sector as a whole, weighted with the tax factors $\left(1-\phi \tau_{i}\right)$.

This may be summarized as

Result 4: Sector-level bargaining: If either wage costs or capital costs are less than fully deductible, an increase in the tax rate may increase or decrease wages. The wage effect converges to zero if the activity of the sector in the jurisdiction where the tax change occurs is small, relative to the rest of the sector.

\section{A.3 Corporate tax incidence in fair wage models}

Consider a firm $i$ with two types of workers. Assume that the fair wage for type $k$ workers employed by firm $i$ is given by the function $w_{i}^{k f}=f_{i}^{k}\left(\bar{w}_{i}^{k}, w_{i}^{-k}, P_{i}\right)$, where $\bar{w}_{i}^{k}$ are unemployment benefits, $w_{i}^{-k}$ are wages of the other skill group in the firm and profits $P_{i}$ are given by

$$
P_{i}=F_{i}\left(K_{i}, L_{i}^{h}, L_{i}^{l}\right)\left(1-\tau_{i}\right)-\sum_{k} w_{i}^{k} L_{i}^{k}\left(1-\phi \tau_{i}\right)-\left(1-\alpha \tau_{i}\right) r K_{i}
$$


We assume that the fair wage function has the following standard properties:

$$
\begin{aligned}
\frac{\partial f_{i}^{k}}{\partial \bar{w}_{i}^{k}}, \frac{\partial f_{i}^{k}}{\partial w_{i}^{-k}}, \frac{\partial f_{i}^{k}}{\partial P_{i}} & >0 \\
\frac{\partial f_{i}^{k}}{\partial w_{i}^{-k}}-\frac{\partial f_{i}^{k}}{\partial P_{i}} L_{-k}\left(1-\phi \tau_{i}\right) & >0 \\
1-\frac{\partial f_{i}^{k}}{\partial w_{i}^{-k}} \frac{\partial f_{i}^{-k}}{\partial w_{i}^{k}} & >0
\end{aligned}
$$

The fair wage is increasing in unemployment benefits $\bar{w}_{i}^{k}$, in the wage of the other skill group employed by the firm and in the firm's profits. Equation (19) implies that the fair wage for skill group $k$ increases if the wage of the other skill group $-k$ increases. This does not follow directly from the first derivatives, as an increase in the wage of the other skill group reduces profits. The effect on profits reduces the fair wage. Equation (20) implies that an increase in any of the reservation wages raises the fair wages of both groups.

In equilibrium, the firm pays fair wages to both types of employees and sets factor inputs to maximize after-tax profits. Optimal factor inputs are given by the standard marginal productivity conditions. Equilibrium wages are given by

$$
w_{i}^{k *}=f_{i}^{k}\left(\bar{w}_{i}^{k}, w_{i}^{-k *}, P_{i}^{*}\right) \quad k=h, l .
$$

Equation (21) implicitly defines the equilibrium wage rates $w_{i}^{h *}$ and $w_{i}^{l *}$ as functions of, among other things, the corporate tax rate $\tau_{i}$. Standard comparative static analysis shows that the effect of a change in $\tau_{i}$ on wages is given by

$$
\frac{\partial w_{i}^{k f *}}{\partial \tau_{i}}=-\frac{T_{i}}{\xi}\left[1+\frac{\partial f_{i}^{-k}}{\partial P_{i}} L_{k}\left(1-\phi \tau_{i}\right)+\frac{\partial f_{i}^{k}}{\partial w_{i}^{-k}}-\frac{\partial f_{i}^{k}}{\partial P_{i}} L_{-k}\left(1-\phi \tau_{i}\right)\right]<0
$$

where

$$
T_{i}=F_{i}\left(K_{i}, L_{i}^{h}, L_{i}^{l}\right)-\phi \sum_{k} w_{i}^{k} L_{i}^{k}-\alpha r K_{i}
$$

is the profit tax base and

$$
\begin{aligned}
\xi & =1-\frac{\partial f_{i}^{k}}{\partial w_{i}^{-k}} \frac{\partial f_{i}^{-k}}{\partial w_{i}^{k}} \\
& +\left(\frac{\partial f_{i}^{k}}{\partial P_{i}}\left(L_{i}^{k}+\frac{\partial f_{i}^{-k}}{\partial w_{i}^{k}} L_{i}^{-k}\right)+\frac{\partial f_{i}^{-k}}{\partial P_{i}}\left(L_{i}^{-k}+\frac{\partial f_{i}^{k}}{\partial w_{i}^{-k}} L_{i}^{k}\right)\right)\left(1-\phi \tau_{i}\right)>0 .
\end{aligned}
$$

This may be summarized as

Result 5: Fair wage model: An increase (decline) in the local corporate tax rate 
reduces (increases) wages.

Result 5 is independent of whether or not wage and capital costs are fully deductible from the tax base.

\section{A.4 Corporate tax incidence in models where wages affect pro- ductivity}

Following Acemoglu and Shimer (1999), we assume that output is uncertain and depends on the quality of firm worker matches. There is only one type of labor. If a firm offers a higher wage, more workers will apply for the job and the chances of a good match increase, given the wages offered by other firms. With probability $\rho_{i}\left(w_{i}, \mathbf{q}\right)$ the additional output produced by filling a vacancy $i$ in a firm located in jurisdiction $j$ equals $Q_{i}\left(K_{i}\right)$, with probability $1-\rho_{i}\left(w_{i}, \mathbf{q}\right)$ it is equal to zero. The wages paid by other firms as well as other factors which may be relevant for the likelihood of success are summarized by the vector $\mathbf{q}$. The function $\rho_{i}\left(w_{i}, \mathbf{q}\right)$ has the following properties ${ }^{53}$ :

$$
\frac{\partial \rho_{i}}{\partial w_{i}}>0, \frac{\partial_{i}^{2} \rho}{\partial w_{i}^{2}}<0, \frac{\partial_{i}^{2} \rho}{\partial w_{i}^{k} \partial \mathbf{q}}=0 .
$$

Expected profits are now given by

$$
P_{i}^{e}=\rho_{i}\left(w_{i}, \mathbf{q}\right) Q_{i}\left(K_{i}\right)\left(1-\tau_{j}\right)-w_{i}\left(1-\phi \tau_{j}\right)-\left(1-\alpha \tau_{j}\right) r K_{i}
$$

The first order conditions for the optimal wage and optimal investment are given by

$$
\frac{\partial \rho_{i}}{\partial w_{i}} Q_{i}\left(K_{i}\right)\left(1-\tau_{j}\right)-\left(1-\phi \tau_{j}\right)=0
$$

and

$$
\rho_{i}\left(w_{i}, \mathbf{q}\right) Q_{i}^{\prime}\left(K_{i}\right)\left(1-\tau_{j}\right)-\left(1-\alpha \tau_{j}\right)=0
$$

Equations (24) and (25) imply that we can write the equilibrium wage rate as a function $w_{i}^{*}=w_{i}^{*}\left(\tau_{i}, \phi, \alpha, r\right)$. Standard comparative static analysis leads to

$$
\frac{\partial w_{i}^{*}}{\partial \tau_{j}}=\frac{1}{\Delta\left(1-\tau_{j}\right)^{2}}\left[\rho_{i}\left(w_{i}, \mathbf{q}\right) Q_{i}^{\prime \prime}\left(K_{i}\right)(1-\phi)-\frac{\partial \rho_{i}}{\partial w_{i}} Q_{i}^{\prime}\left(K_{i}\right)(1-\alpha)\right] \leq 0
$$

\footnotetext{
${ }^{53}$ The assumption that all cross derivatives are equal to zero is made to simplify the exposition, it is not necessary for the results.
} 
where

$$
\Delta=\rho_{i}\left(w_{i}, \mathbf{q}\right) Q_{i}^{\prime \prime}\left(K_{i}\right) \frac{\partial_{i}^{2} \rho}{\partial w_{i}{ }^{2}} Q_{i}\left(K_{i}\right)-\left[\frac{\partial \rho_{i}}{\partial w_{i}} Q_{i}^{\prime}\left(K_{i}\right)\right]^{2}>0 .
$$

Note that $\Delta>0$ follows from the second order conditions for profit maximization. A higher corporate tax rate thus reduces the wage if there is limited deductibility of either wage or capital costs. This may be summarized as

Result 6: Models where wages affect productivity: If either wage costs or capital costs are less than fully deductible, an increase (decline) in the local corporate tax rate reduces (increases) wages.

\section{A.5 Monopsonistic labor market}

Consider a firm which employs a technology with a constant marginal productivity of labor denoted by $A_{i}$. Labor supply is given by $L_{i}=w_{i}^{\eta}$ where $\eta>0$ is the elasticity of labor supply. The firm's after-tax profit is given by

$$
P_{i}^{M}\left(w_{i}\right)=A_{i} L\left(1-\tau_{j}\right)-w_{i} L_{i}\left(1-\phi \tau_{j}\right)
$$

Substituting $L=w^{\eta}$ into the profit function and maximizing over the wage yields the equilibrium wage rate as

$$
w_{i}^{*}=A_{i} \frac{\eta}{1+\eta} \frac{\left(1-\tau_{j}\right)}{\left(1-\phi \tau_{j}\right)}
$$

which implies

$$
\frac{\partial w_{i}^{*}}{\partial \tau_{j}}=-A_{i} \frac{\eta}{1+\eta} \frac{(1-\phi)}{\left(1-\phi \tau_{j}\right)^{2}}<0, \frac{\partial^{2} w_{i}^{*}}{\partial \tau_{j} \partial \eta}=-A_{i} \frac{1}{(1+\eta)^{2}} \frac{(1-\phi)}{\left(1-\phi \tau_{j}\right)^{2}}<0,
$$

leading to

Result 7: Monopsonistic labor market: If either wage costs or capital costs are less than fully deductible, an increase (decline) in the local corporate tax rate reduces (increases) wages. The magnitude of the effect is increases with the elasticity of labor supply.

We next consider a more general version of the model, where we relax the assumption that the marginal productivity of labor and the elasticity of labor supply are constant and instead consider a standard, strictly concave production function $F\left(K_{i}, L_{i}\right)$ with the usual neoclassical properties and weak complementarity between labor and capital: $\frac{\partial^{2} F\left(K_{i}, L^{s}\left(w_{i}\right)\right)}{\partial K_{i} \partial L_{i}} \geq 0$. Denote the labor supply function by $L^{s}=L^{s}(w), L^{s \prime}(w)>0$. Profits 
are given by

$$
P_{i}^{M}\left(K_{i}, w_{i}\right)=F\left(K_{i}, L^{s}\left(w_{i}\right)\right)\left(1-\tau_{j}\right)-w_{i} L^{s}\left(w_{i}\right)\left(1-\phi \tau_{j}\right)-\left(1-\alpha \tau_{i}\right) r K_{i}
$$

where the first order conditions for profit maximization are

$$
\begin{array}{r}
\frac{\partial F\left(K_{i}, L^{s}\left(w_{i}\right)\right)}{\partial L_{i}} L^{s \prime}\left(w_{i}\right)\left(1-\tau_{j}\right)-\left(L^{s \prime}\left(w_{i}\right) w_{i}+L^{s}\left(w_{i}\right)\right)\left(1-\phi \tau_{j}\right)=0 \\
\frac{\partial F\left(K_{i}, L^{s}\left(w_{i}\right)\right)}{\partial K_{i}}\left(1-\tau_{j}\right)-\left(1-\alpha \tau_{j}\right) r=0
\end{array}
$$

Equations (27) and (28) implicitly define the profit maximizing wage rate $w_{i}^{*}$ and the capital stock set by the monopsonist, as functions of the tax corporate rate. Standard comparative static analysis leads to

$\frac{\partial w_{i}^{*}}{\partial \tau_{j}}=\frac{1}{\Gamma}\left[\frac{\partial^{2} F\left(K_{i}, L^{s}\left(w_{i}\right)\right)}{\partial K_{i}^{2}}\left(L^{s \prime}\left(w_{i}\right) w_{i}+L^{s}\left(w_{i}\right)\right)(1-\phi)-\frac{\partial^{2} F\left(K_{i}, L^{s}\left(w_{i}\right)\right)}{\partial K_{i} \partial L_{i}} L^{s \prime}\left(w_{i}\right)(1-\phi)\right]<0$.

where the second order conditions imply

$$
\Gamma=\frac{\partial^{2} P_{i}^{M}\left(K_{i}, w_{i}\right)}{\partial K_{i}^{2}} \frac{\partial^{2} P_{i}^{M}\left(K_{i}, w_{i}\right)}{\partial w_{i}^{2}}-\left[\frac{\partial^{2} P_{i}^{M}\left(K_{i}, w_{i}\right)}{\partial K_{i} \partial w_{i}}\right]^{2}>0
$$

\section{A.6 Extensions}

\section{A.6.1 Firms operating in multiple jurisdictions with formula apportionment}

Consider a company with plants in two jurisdictions, 1 and 2. As a first step, we assume that there is just one type of labor. Employment (capital) in jurisdiction $j$ is denoted by $L_{j}\left(K_{j}\right), j=1,2$. The wage rate is the same in both plants. After-tax profits of the company are

$$
P_{i}^{F A}=F\left(K_{1}, K_{2}, L_{1}, L_{2}\right)\left(1-\tau_{i}\right)-\left(1-\phi \tau_{i}\right) w\left[L_{1}+L_{2}\right]-\left(1-\alpha \tau_{i}\right) r\left[K_{1}+K_{2}\right]
$$

Assume that the tax apportionment formula is based on payroll as the only apportionment factor. ${ }^{54}$ Given that there is a uniform wage rate in the two plants, the profit tax rate is given by

$$
\tau_{i}=\frac{\tau_{1} L_{1}+\tau_{2} L_{2}}{L_{1}+L_{2}}
$$

The effect of a tax rate change in one jurisdiction on the firm's effective profit tax

${ }^{54}$ This is the case for the German LBT. 
rate $\tau$, given the level of employment, is

$$
\frac{\partial \tau_{i}}{\partial \tau_{j}}=\frac{L_{j}}{L_{1}+L_{2}}, \quad j=1,2
$$

where $\tau_{j}$ is the tax rate of jurisdiction $j$. How does a change in a local corporate tax rate affect wages in this setting? Assume that wages are set via collective bargaining which takes place at the firm-level, not at the plant-level, and that wages paid to workers of a given skill group are the same in the two plants. The objective function of the skill type $k$ union is now given by

$$
Z^{F A}=\left(L_{1}+L_{2}\right)(w-\bar{w})=\left(L_{1}+L_{2}\right) s^{F A} .
$$

The outcome of the bargaining process is given by

$$
s^{F A *}, L_{1}^{*}, L_{2}^{*}=\arg \max _{s^{F A}, L_{1}, L_{2}} \Omega^{F A}
$$

where

$$
\Omega^{F A}=\lambda \ln Z_{i}^{F A}+(1-\lambda) \ln P_{i}^{F A} .
$$

The variable $\lambda^{k} \in(0,1)$ stands for the relative bargaining power of the union. The first order condition for the wage rate yields

$$
s^{F A *}=\lambda \frac{\Pi_{i}^{F A}}{\left[\left(L_{2}+L_{2}\right)\left(1-\phi \tau_{i}\right)\right]}
$$

where

$$
\Pi_{i}^{F A}=F\left(K_{1}, K_{2}, L_{1}, L_{2}\right)\left(1-\tau_{i}\right)-\left(1-\phi \tau_{i}\right) \bar{w}\left[L_{1}+L_{2}\right]-\left(1-\alpha \tau_{i}\right) r\left[K_{1}+K_{2}\right]
$$

For given levels of employment, the change in the wage premium caused by a change in the tax rate is given by

$$
\left.\frac{\partial s^{F A *}}{\partial \tau_{j}}=-\lambda \frac{L_{j}}{\left(L_{1}+L_{2}\right)^{2}}\left[\left(F\left(K_{1}, K_{2}, L_{1}, L_{2}\right)-r\left(K_{1}+K_{2}\right)\right)(1-\phi)\right]+(1-\alpha) r\left(K_{1}+K_{2}\right)\right] \leq 0
$$

This implies:

Result 8: Formula apportionment and firm-level bargaining: In firms with plants in many jurisdictions and homogeneous labor, where corporate taxation is based on formula apportionment, and if wages are set via collective bargaining at the firm-level and either wage or capital costs are less than fully deductible, an increase in the corporate tax rate in one jurisdiction decreases wages in the entire firm. If employment in the jurisdiction that changes the tax rate is small, relative to employment in the firm as a whole, the tax 
effect is also small.

Consider next the case of two skill types, $k=h, l$. After-tax profits of the company are now

$P_{i}^{F A_{k}}=F\left(K_{1}, K_{2} L_{1}^{h}, L_{1}^{l}, L_{2}^{h}, L_{2}^{l}\right)\left(1-\tau_{i}\right)-\left(\sum_{j} \sum_{k} w^{k} L_{j}^{k}\right)\left(1-\phi \tau_{i}\right)-\left(1-\alpha \tau_{i}\right) r\left[K_{1}+K_{2}\right]$

with obvious notation. The profit tax rate is given by

$$
\tau_{i}=\frac{\sum_{j} \sum_{k} \tau_{j} w^{k} L_{j}^{k}}{\sum_{j} \sum_{k} w^{k} L_{j}^{k}}
$$

For given employment, the effect of a tax rate change in one jurisdiction on the firm's effective profit tax rate $\tau_{i}$ is

$$
\frac{\partial \tau_{i}}{\partial \tau_{j}}=\frac{\sum_{k} w^{k} L_{j}^{k}}{\sum_{j} \sum_{k} w^{k} L_{j}^{k}} .
$$

The effect of a wage change for workers of skill type $h$ on the effective profit tax rate is:

$$
\frac{\partial \tau_{i}}{\partial w^{h}}=\left[\tau_{1}-\tau_{2}\right]\left[\frac{L_{1}^{h}}{L_{1}^{l}}-\frac{L_{2}^{h}}{L_{2}^{l}}\right] L_{1}^{l} L_{2}^{l} \frac{1}{\sigma}
$$

where

$$
\sigma=\left[1+\frac{w^{h} L_{1}^{h}+w^{l} L_{1}^{l}}{w^{h} L_{2}^{h}+w^{l} L_{2}^{l}}\right]^{2}\left[w^{h} L_{2}^{h}+w^{l} L_{2}^{l}\right]^{2}>0 .
$$

Assume, for instance, that municipality 1 has a higher tax rate than municipality 2. The effect of an increase in the wage of the high skilled $w^{h}$ on the tax burden will depend on whether this increases the payroll share of the high tax municipality, or that of the low tax municipality. If the share of high skilled is higher in jurisdiction 1 , so that $\left[\frac{L_{1}^{h}}{L_{1}^{l}}-\frac{L_{2}^{h}}{L_{2}^{l}}\right]>0$, the tax rate $\tau_{i}$ will increase, and vice versa. The effect of a wage change on the profit tax rate a firm effectively pays, is therefore generally ambiguous.

Once again assuming firm-level collective bargaining and homogeneous wages for a skill group across plants, the objective function of the skill type $k$ union is now given by

$$
Z^{F A k}=\left(L_{1}^{k}+L_{2}^{k}\right)\left(w_{1}^{k}-\bar{w}^{k}\right)=\left(L_{1}^{k}+L_{2}^{k}\right) s^{F A^{k}} .
$$


The outcome of the bargaining process is given by

$$
s^{F A^{k *}}, L_{1}^{k *}, L_{2}^{k *}=\arg \max _{s^{k}, L_{1}^{k}, L_{2}^{k}} \Omega^{F A k}
$$

where

$$
\Omega^{F A k}=\lambda^{k} \ln Z_{i}^{F A k}+\left(1-\lambda^{k}\right) \ln P_{i}^{F A t} .
$$

As above, the variable $\lambda^{k} \in(0,1)$ stands for relative bargaining power of the skill type $k$ union. The first order condition for the wage rate yields

$$
s^{F A^{k *}}=\frac{\lambda^{k}}{\left(1-\lambda^{k}\right)} \frac{P^{F A t}}{\left[\left(L_{1}^{k}+L_{2}^{k}\right)\left(1-\phi \tau_{i}\right)-\Phi_{w}^{k}\right]}, \quad k=h, l
$$

where

$$
\Phi_{w}^{k}=\frac{\partial P_{i}^{F A}}{\partial \tau_{i}} \frac{\partial \tau_{i}}{\partial w^{k}}
$$

The key difference between this case and that with homogeneous labor, is that a wage change now affects the effective tax rate. It thus influences the outcome of union-firm bargaining. For instance, if a higher wage increases the effective tax rate, which implies $\Phi_{w k}<0$, the wage premium achieved by the union will be smaller, other things equal, and vice versa. Equation (30) implicitly defines the two firm specific wage premiums emerging from the bargaining process as functions of the type $s^{F A k *}=s^{F A k *}\left(\tau_{i}, \tau_{j}, T, L_{i}^{k *}, L_{j}^{k *} \ldots\right)$. Differentiating (30) shows that the change in the local corporate tax rate on wages is, in general, ambiguous.

\section{A.6.2 Income shifting to avoid taxes}

In this section we extend the model to include income shifting. Assume that the firm's profits are given by

$$
P_{i j}^{S}=p_{i} F_{i}\left(K_{i}, L_{i}^{h}, L_{i}^{l}\right)\left(1-\tau_{j}\right)-\sum_{k} w_{i}^{k} L_{i}^{k}\left(1-\phi_{j} \tau_{j}\right)-\left(1-\alpha_{j} \tau_{j}\right) r_{i} K_{i}+\theta_{i j} S_{i}-c\left(S_{i}\right)
$$

The variable $S_{i}$ is income shifted from the profit tax base to the personal income tax base of the firm owners, which may be positive or negative, $\theta_{i j}$ is the tax benefit per unit of income shifted and $c\left(S_{i}\right)$ is a convex shifting cost function. ${ }^{55}$ Profit maximizing factor

\footnotetext{
${ }^{55}$ Here we assume that profit shifting is carried out by changing the wages of firm owners working in the firm or family members of the firm owner. This implies that $s_{i}$ would be reported as wage income. Another way of shifting income is to provide capital in the form of debt, rather than equity. Many countries have introduced anti tax avoidance legislation which limits income shifting. We therefore take into account costs of income shifting. This can be interpreted as the cost of hiring tax consultants or the cost of concealing income shifting. For notational simplicity we assume that shifting costs themselves are
} 
input decisions lead to the usual marginal productivity conditions, and optimal income shifting implies $c^{\prime}\left(S_{i}\right)=\theta_{i j}$ so that the profit maximizing amount of shifted income $S_{i}^{*}$ can be expressed as a function of the tax benefit $S_{i}^{*}=S_{i}^{*}\left(\theta_{i j}\right)$, with $S_{i}^{* \prime}>0$. Consider first the case of a multinational company which is able to shift income abroad. If the firm can do so, for instance, through a foreign subsidiary charging a fully deductible cost to the domestic parent company, the tax advantage from income shifting is given by $\theta_{i j}=$ $\tau_{j}-\tau_{f}$, where $\tau_{f}$ is the foreign profit tax rate. Assume that wages in the multinational firm are determined by firm-level bargaining. In this case the wage premium generated by union firm bargaining is given by

$$
z_{i}^{k *}=\frac{\left(1-\beta_{i}^{j}\right) \beta_{i}^{k}}{\left(1-\beta_{i}^{k} \beta_{i}^{j}\right)} \frac{\Pi_{i}^{S}}{L_{i}^{k}\left(1-\phi \tau_{i}\right)} \quad k, j=h, l, \quad k \neq j
$$

where

$$
\Pi_{i}^{S}=F\left(K_{i}, L_{i}^{h}, L_{i}^{l}\right)\left(1-\tau_{i}\right)-\sum_{k} \bar{w}^{k} L_{i}^{k}\left(1-\phi \tau_{i}\right)-\left(1-\alpha \tau_{i}\right) r K_{i}+\left(\tau_{j}-\tau_{f}\right) S_{i}-c\left(S_{i}\right) .
$$

Differentiating (32) yields

$$
\begin{array}{r}
\frac{d z_{i}^{k *}}{d \tau_{i}} L_{i}^{k}+z_{i}^{k *} \frac{d L_{i}^{k}}{d \tau_{i}}= \\
\left.-\beta_{0}^{S}\left[F\left(K_{i}, L_{i}^{h}, L_{i}^{l}\right)-r K_{i}-S_{i}\right](1-\phi)+(1-\alpha) r K_{i}-\phi\left(S_{i}\left(1-\tau_{f}\right)-c\left(S_{i}\right)\right)\right] \leq 0
\end{array}
$$

where

$$
\beta_{0}^{S}=\frac{\left(1-\beta_{i}^{j}\right) \beta_{i}^{k}}{\left(1-\beta_{i}^{k} \beta_{i}^{j}\right)\left(1-\phi \tau_{i}\right)^{2}}>0 \quad k, j=h, l, \quad k \neq j .
$$

The right-hand side of (33) is increasing in $S_{i}$ (given that $S_{i}=S_{i}^{*}$ ), which implies that the decline in the rent accruing to labor is smaller, the higher the equilibrium level of income shifting. What happens in the case of domestic income shifting between the profit tax base and wage income? In this case the tax advantage from income shifting is given by $\theta_{i j}=\phi_{j} \tau_{j}-t_{p i}$, where $t_{p i}$ is the marginal tax rate on wage income of the relevant employee. This is relevant in settings where the wages of some employees are effectively profit distributions, so that wage bargaining plays no role for them. Assume that the wages paid in the absence of incentives for income shifting, that is for equal taxes on profits and labor income, would be given by the function $w_{i}^{k S}\left(\tau_{j}, \phi \ldots\right)$. Then the observed change in the wages paid out by the firm would equal $\sum_{k} \frac{d w_{i}^{k S}}{d \tau_{j}} L_{i}^{k}+\frac{d S_{i}}{d \tau_{j}}$. While 'true' wages are likely to decline in response to higher taxes, albeit by less than they would in the absence of income shifting possibilities, we now have the additional effect not tax deductible. 
that the income shifting effect $\frac{d S_{i}}{d \tau_{j}}>0$ increases reported wages. Thus if income shifting is important, we would expect observed wages to decline less, or even increase, in response to higher corporate taxes. This may be summarized as

Result 9 Income shifting: If firms engage in international income shifting and wages are set by firm-level bargaining, then the decline in the rent accruing to labor caused by a higher corporate tax decreases as the equilibrium level of income shifting increases. If firms can shift income between the profit tax base and the labor income tax base, reported wages will decline less than in the absence of income shifting or may even increase in response to a higher corporate tax rate.

\section{B German business taxes}

As mentioned in Section 3, there are two other profit taxes in Germany, the corporate tax (CT), which applies to corporations, and the personal income tax (PIT), which applies to non-corporate firms. We discuss the most important features of these two taxes in turn.

Corporate tax. The rate of the nationwide corporate income tax, $\tau_{C T}$, has undergone several changes in recent years. Until 2000, a split rate imputation system existed in Germany, where retained profits were subject to a tax rate of $45 \%$ in 1998 and $40 \%$ in 1999 and 2000. Dividends were taxed at a rate of 30\% from 1998 to 2000. As of 2001, retained and distributed profits were taxed equally at $25 \%$ (26.5\% in 2003). In 2008, $\tau_{C T}$ was lowered to $15 \%$. In all years, a so-called solidarity surcharge (to finance the costs of reunification), soli, of $5.5 \%$ of the corporate tax rate was added.

There are two steps to calculating the total statutory tax rate for corporate firms. First, LBT and CT rates are added. Second, the deduction of the LBT payments from the tax base has to be taken into account. The statutory tax rate for corporate firms, $\tau^{c o r p}$, from 1998 to 2007 , is $\tau^{c o r p}=\frac{\tau_{C T} \cdot(1+s o l i)+\tau_{L B T}^{f e d} \cdot \tau_{L B T}^{m u n}}{1+\tau_{L B T}^{f e d} \cdot \tau_{L B T}^{m u n}}$. Since 2008, the denominator of the equation is equal to 1 , as the LBT can no longer be deducted from the tax base.

Personal income tax. Non-corporate firms (Personengesellschaften) are subject to the progressive personal income tax (on operating profits assigned to the proprietor). Non-corporate firms have an LBT allowance of 24,500 euros and a reduced $\tau_{L B T}^{f e d}$ for small non-corporate firms prior to 2008: for every 12,000 euros exceeding the allowance of 24,500 euros, $\tau_{L B T}^{f e d}$ was raised by one percentage point so that the full basic federal rate of $5.0 \%$ had to be paid only for taxable income exceeding 72,500 euros. The tax rate for a non-corporate firms $\tau^{\text {non-corp }}$ from 1998 to 2007 , is $\tau^{\text {non-corp }}=\frac{\tau_{P I T} \cdot(1+s o l i)+\tau_{L B T}^{f e d} \cdot \tau_{L B T}^{\text {mun }}}{1+\tau_{L B T}^{f e d} \cdot 1.8}$. The denominator of the equation shows that a fixed share of the LBT liabilities can be 
deducted from the personal income tax base. This share amounted to $1.8 \cdot \tau_{L B T}^{f e d} \cdot Y$ from 2001 to 2007 and $3.8 \cdot \tau_{L B T}^{f e d} \cdot Y$ from 2008 onwards.

\section{Descriptive Statistics}

Table C.1: Local business tax rates (in \%), 1993-2012

\begin{tabular}{ccccccc}
\hline \hline & mean & min & P5 & P50 & P95 & max \\
\hline 1993 & 312 & 0 & 250 & 310 & 370 & 737 \\
1994 & 314 & 100 & 250 & 310 & 372 & 515 \\
1995 & 317 & 0 & 260 & 320 & 379 & 515 \\
1996 & 319 & 0 & 261 & 320 & 380 & 515 \\
1997 & 320 & 0 & 270 & 320 & 380 & 515 \\
1998 & 322 & 0 & 270 & 320 & 380 & 900 \\
1999 & 323 & 0 & 270 & 320 & 380 & 900 \\
2000 & 324 & 0 & 271 & 320 & 380 & 900 \\
2001 & 326 & 0 & 275 & 325 & 380 & 900 \\
2002 & 327 & 0 & 277 & 330 & 385 & 900 \\
2003 & 329 & 0 & 280 & 330 & 400 & 900 \\
2004 & 330 & 0 & 280 & 330 & 400 & 900 \\
2005 & 332 & 0 & 280 & 330 & 400 & 900 \\
2006 & 333 & 200 & 285 & 330 & 400 & 900 \\
2007 & 334 & 0 & 290 & 330 & 400 & 900 \\
2008 & 335 & 0 & 290 & 330 & 400 & 900 \\
2009 & 336 & 0 & 290 & 330 & 400 & 900 \\
2010 & 338 & 200 & 300 & 340 & 400 & 900 \\
2011 & 344 & 200 & 300 & 350 & 400 & 900 \\
2012 & 347 & 200 & 300 & 350 & 403 & 900 \\
total & 328 & 0 & 275 & 330 & 395 & 900 \\
\hline \hline Source: & Statistical Offices of the Länder. &
\end{tabular}


Table C.2: Tax changes per municipality, 1993-2012

\begin{tabular}{|c|c|c|c|c|}
\hline \multirow[b]{2}{*}{ changes } & \multicolumn{2}{|c|}{ any change } & \multicolumn{2}{|c|}{ big change } \\
\hline & municipalities & in $\%$ & municipalities & in $\%$ \\
\hline \multicolumn{5}{|c|}{ all municipalities } \\
\hline 0 & 1733 & 15.10 & 3963 & 34.60 \\
\hline 1 & 2968 & 25.90 & 4657 & 40.70 \\
\hline 2 & 3064 & 26.80 & 2185 & 19.10 \\
\hline 3 & 1785 & 15.60 & 552 & 4.80 \\
\hline 4 & 730 & 6.40 & 76 & 0.70 \\
\hline 5 or more & 1161 & 10.10 & 8 & 0.10 \\
\hline \multicolumn{5}{|c|}{ non-merged municipalities } \\
\hline 0 & 1636 & 16.40 & 3566 & 35.70 \\
\hline 1 & 2832 & 28.30 & 4107 & 41.10 \\
\hline 2 & 2898 & 29.00 & 1815 & 18.10 \\
\hline 3 & 1659 & 16.60 & 445 & 4.40 \\
\hline 4 & 623 & 6.20 & 63 & 0.60 \\
\hline 5 or more & 353 & 3.50 & 5 & 0.00 \\
\hline \multicolumn{5}{|c|}{ merged municipalities } \\
\hline 0 & 97 & 6.70 & 397 & 27.60 \\
\hline 1 & 136 & 9.40 & 550 & 38.20 \\
\hline 2 & 166 & 11.50 & 370 & 25.70 \\
\hline 3 & 126 & 8.80 & 107 & 7.40 \\
\hline 4 & 107 & 7.40 & 13 & 0.90 \\
\hline 5 or more & 808 & 56.10 & 3 & 0.20 \\
\hline
\end{tabular}

Source: Statistical Offices of the Länder. Notes: Big change defined as an increase of $\tau_{L B T}^{m u n}$ by 20 percentage points or more. 
Table C.3: Time variation in local tax rates, 1993-2012

\begin{tabular}{|c|c|c|c|c|c|c|}
\hline \multirow[t]{2}{*}{ municip. with a ... } & \multicolumn{2}{|c|}{... tax change } & \multicolumn{2}{|c|}{... tax increase } & \multicolumn{2}{|c|}{... tax decrease } \\
\hline & share & mean change & share & mean increase & share & mean decrease \\
\hline all municip. & 12.4 & 15 & 10.4 & 21 & 2.0 & -15 \\
\hline non-merged municip. & 9.5 & 19 & 8.9 & 23 & 0.6 & -32 \\
\hline merged municip. & 32.9 & 7 & 21.2 & 16 & 11.7 & -9 \\
\hline \multicolumn{7}{|c|}{ by year (non-merged municipalities only) } \\
\hline 1994 & 10.9 & 18 & 10.1 & 24 & 0.9 & -47 \\
\hline 1995 & 15.6 & 19 & 15.0 & 22 & 0.6 & -51 \\
\hline 1996 & 11.2 & 16 & 10.7 & 19 & 0.5 & -39 \\
\hline 1997 & 8.6 & 18 & 8.1 & 22 & 0.5 & -41 \\
\hline 1998 & 8.7 & 18 & 8.2 & 22 & 0.5 & -34 \\
\hline 1999 & 4.3 & 12 & 3.7 & 20 & 0.6 & -39 \\
\hline 2000 & 8.8 & 12 & 7.9 & 17 & 0.9 & -32 \\
\hline 2001 & 12.9 & 15 & 11.8 & 19 & 1.1 & -23 \\
\hline 2002 & 8.3 & 17 & 7.8 & 20 & 0.5 & -43 \\
\hline 2003 & 9.7 & 20 & 9.3 & 22 & 0.4 & -31 \\
\hline 2004 & 8.5 & 19 & 8.1 & 21 & 0.3 & -32 \\
\hline 2005 & 11.5 & 18 & 11.1 & 20 & 0.5 & -27 \\
\hline 2006 & 8.4 & 14 & 7.5 & 19 & 0.9 & -28 \\
\hline 2007 & 4.1 & 11 & 3.3 & 20 & 0.8 & -26 \\
\hline 2008 & 4.0 & 18 & 3.2 & 28 & 0.8 & -26 \\
\hline 2009 & 4.2 & 18 & 3.5 & 27 & 0.8 & -20 \\
\hline 2010 & 8.8 & 27 & 8.4 & 30 & 0.4 & -22 \\
\hline 2011 & 18.5 & 29 & 18.2 & 29 & 0.3 & -21 \\
\hline 2012 & 12.9 & 26 & 12.6 & 27 & 0.3 & -32 \\
\hline
\end{tabular}

Source: Statistical Offices of the Länder. Notes: Share in \%; changes in percentage points. 
Table C.4: Descriptive statistics, plant sample, LIAB 1998-2008

\begin{tabular}{|c|c|c|c|}
\hline & mean & $\mathrm{p} 50$ & sd \\
\hline Wage & 2,555 & 2,539 & 870 \\
\hline Local tax rate & 371 & 365 & 52 \\
\hline Share: Tax increases & 0.12 & 0.00 & 0.33 \\
\hline Share: Tax big decrease & 0.03 & 0.00 & 0.16 \\
\hline Share: Tax decreases & 0.03 & 0.00 & 0.17 \\
\hline Municipal expenses (in Thsds.) & 312,405 & 44,560 & 700,018 \\
\hline Municipal population & 98,613 & 26,456 & 183,536 \\
\hline District unemployment rate & 0.13 & 0.12 & 0.06 \\
\hline District GDP (in Mio) & 7,667 & 4,772 & 10,234 \\
\hline Share: Merged non-merged municipalities & 0.72 & 1.00 & 0.44 \\
\hline Share: Merged municipalities & 0.28 & 0.00 & 0.44 \\
\hline Share: West German municipalities & 0.62 & 1.00 & 0.49 \\
\hline Share: East German municipalities & 0.38 & 0.00 & 0.49 \\
\hline Number of employees & 239 & 52 & 1006.06 \\
\hline Value added (in 1000) & 129,606 & 2164 & $4,950,000$ \\
\hline Investments (in 1000) & 3212 & 162 & 23,425 \\
\hline EBITDA & 126,485 & 777 & $5,100,000$ \\
\hline Share: Liable plants & 0.64 & 1.00 & 0.48 \\
\hline Share: Non-liable plants & 0.36 & 0.00 & 0.48 \\
\hline Share: Corporate & 0.58 & 1.00 & 0.49 \\
\hline Share: Non-corporate & 0.42 & 0.00 & 0.49 \\
\hline Share: Single plant firms & 0.64 & 1.00 & 0.48 \\
\hline Share: Part of multi-plant firm & 0.36 & 0.00 & 0.48 \\
\hline Share: Sector level bargaining & 0.54 & 1.00 & 0.50 \\
\hline Share: Firm level bargaining & 0.09 & 0.00 & 0.28 \\
\hline Share: No collective & 0.37 & 0.00 & 0.48 \\
\hline Share: Manufacturing & 0.62 & 1.00 & 0.49 \\
\hline Share: Services & 0.38 & 0.00 & 0.49 \\
\hline Share: High profitability & 0.37 & 0.00 & 0.48 \\
\hline Share: Medium profitability & 0.34 & 0.00 & 0.47 \\
\hline Share: Low profitability & 0.29 & 0.00 & 0.45 \\
\hline
\end{tabular}

Source: LIAB and Statistical Offices of the Länder. Notes: Total number of plantyear observations: 77,357. Number of plants: 21,474. All money variables in 2008 euros. 
Table C.5: Descriptive statistics, individual sample, LIAB 1998-2008

\begin{tabular}{|c|c|c|c|}
\hline & mean & $\mathrm{p} 50$ & sd \\
\hline Wage & 3,358 & 3,230 & 1,109 \\
\hline Local tax rate & 392 & 393 & 54 \\
\hline Share: Tax increases & 0.09 & 0.00 & 0.28 \\
\hline Share: Big tax increases & 0.02 & 0.00 & 0.14 \\
\hline Share: Tax decreases & 0.03 & 0.00 & 0.13 \\
\hline Municipal expenses (in Thsd.) & 672,000 & 195,000 & $1,060,000$ \\
\hline Municipal population & 195,919 & 75,911 & 270,393 \\
\hline District unemployment rate & 0.12 & 0.11 & 0.05 \\
\hline District GDP (in million) & 12,600 & 6,950 & 15,400 \\
\hline Share: Non-merged municipalities & 0.84 & 1.00 & 0.37 \\
\hline Share: Merged municipalities & 0.16 & 0.00 & 0.37 \\
\hline Share: West German municipalities & 0.78 & 1.00 & 0.42 \\
\hline Share: East German municipalities & 0.22 & 0.00 & 0.41 \\
\hline Number of employees & 4,875 & 908 & 10,636 \\
\hline Value added (in Thsds.) & $3,030,000$ & 74,627 & $29,700,000$ \\
\hline Investments (in Thsds.) & 67,865 & 5,411 & 187,700 \\
\hline EBITDA (in Thsds.) & $2,990,000$ & 29,408 & $31,000,000$ \\
\hline Share: Liable firms & 0.69 & 1.00 & 0.46 \\
\hline Share: Non-liable firms & 0.29 & 0.00 & 0.46 \\
\hline Share: Corporate & 0.72 & 1.00 & 0.45 \\
\hline Share: Non-corporate & 0.28 & 0.00 & 0.45 \\
\hline Age & 41.65 & 42.00 & 10.02 \\
\hline Share: Male & 0.71 & 1.00 & 0.45 \\
\hline Share: High-skilled & 0.14 & 0.00 & 0.35 \\
\hline Share: Medium skilled & 0.73 & 1.00 & 0.44 \\
\hline Share: Low-skilled & 0.13 & 0.00 & 0.34 \\
\hline Share: Blue collar & 0.54 & 1.00 & 0.50 \\
\hline Share: White collar & 0.46 & 0.00 & 0.50 \\
\hline Share: Never censored individuals & 0.83 & 1.00 & 0.38 \\
\hline
\end{tabular}

Source: LIAB and Statistical Offices of the Länder. Notes: Number of person-year observations: 11,611,037. Number of individuals: 3,917,005. All money variables in 2008 euros. 


\section{Sensitivity Checks}

Table D.6: Sensitivity of baseline estimates w.r.t. level of clustering

\begin{tabular}{|c|c|c|c|c|c|c|}
\hline year & muni $\times$ year & baseline & county & $\mathrm{CC}$ & state & firm \\
\hline \multirow[t]{2}{*}{-4} & $0.00018^{* *}$ & 0.00018 & 0.00018 & 0.00018 & 0.00018 & 0.00018 \\
\hline & $(0.00009)$ & $(0.00012)$ & $(0.00012)$ & $(0.00012)$ & $(0.00011)$ & $(0.00012)$ \\
\hline \multirow[t]{2}{*}{-3} & 0.00010 & 0.00010 & 0.00010 & 0.00010 & 0.00010 & 0.00010 \\
\hline & $(0.00008)$ & $(0.00010)$ & $(0.00010)$ & $(0.00011)$ & $(0.00013)$ & $(0.00011)$ \\
\hline \multirow[t]{2}{*}{-2} & -0.00007 & -0.00007 & -0.00007 & -0.00007 & -0.00007 & -0.00007 \\
\hline & $(0.00008)$ & $(0.00009)$ & $(0.00010)$ & $(0.00010)$ & $(0.00008)$ & $(0.00009)$ \\
\hline \multirow[t]{2}{*}{0} & -0.00012 & -0.00012 & -0.00012 & -0.00012 & -0.00012 & -0.00012 \\
\hline & $(0.00008)$ & (0.00008) & $(0.00008)$ & $(0.00008)$ & $(0.00007)$ & $(0.00009)$ \\
\hline \multirow[t]{2}{*}{1} & $-0.00019 *$ & $-0.00019^{*}$ & ${ }^{*}-0.00019^{* *}$ & ${ }^{k}-0.00019^{*>}$ & * $-0.00019^{*}$ & $*-0.00019 *$ \\
\hline & $(0.00008)$ & $(0.00009)$ & $(0.00010)$ & $(0.00010)$ & $(0.00006)$ & $(0.00010)$ \\
\hline \multirow[t]{2}{*}{2} & $-0.00032^{* *}$ & $*-0.00032 *$ & $k *-0.00032 * *$ & $k *-0.00032^{* *}$ & **-0.00032* & $* * 0.00032^{* * *}$ \\
\hline & $(0.00009)$ & $(0.00011)$ & $(0.00011)$ & $(0.00011)$ & $(0.00008)$ & $(0.00012)$ \\
\hline \multirow[t]{2}{*}{3} & $-0.00036^{* *}$ & $*-0.00036^{*}$ & k*_-0.00036* & $k *-0.00036^{* *}$ & **_-0.00036* & $-0.00036^{* * *}$ \\
\hline & $(0.00009)$ & $(0.00012)$ & $(0.00013)$ & $(0.00014)$ & $(0.00014)$ & $(0.00013)$ \\
\hline \multirow[t]{2}{*}{4} & $-0.00037^{*}$ & $*-0.00037^{*}$ & $k *-0.00037^{* *}$ & $k *-0.00037 * x$ & **_-0.00037* & $* * 0.00037^{* * *}$ \\
\hline & $(0.00009)$ & $(0.00013)$ & $(0.00014)$ & $(0.00013)$ & $(0.00012)$ & $(0.00014)$ \\
\hline \multirow[t]{2}{*}{5} & $-0.00047^{* *}$ & $*-0.00047^{*}$ & $k *-0.00047^{* *}$ & $k *-0.00047 *>$ & **_-0.00047 & $* * 0.00047^{* * *}$ \\
\hline & $(0.00010)$ & $(0.00015)$ & $(0.00016)$ & $(0.00016)$ & $(0.00014)$ & $(0.00015)$ \\
\hline
\end{tabular}

Source: LIAB. Notes: This table shows the regression estimates from our baseline estimate shown in Figure 2 for different levels of clustering of the standard errors. The estimation sample is liable firms in non-merged municipalities $(N=36090$, the number of firms is 10,920). All specifications include "state x year" fixed effects and municipal controls. In the baseline (column 2), standard errors are clustered at the municipal level. In column 1, standard errors are clustered at the (lower) municipal $\times$ year level. In columns 3-5, clustering is at the higher county, commuting zone (CC) and state level, respectively. In column 6 , standard errors are clustered at the firm level. Significance levels are ${ }^{*}<0.10,{ }^{* *}<0.05,{ }^{* * *}$ $<0.01$. 
Figure D.1: Effects on firm wages - Merged vs. non-merged

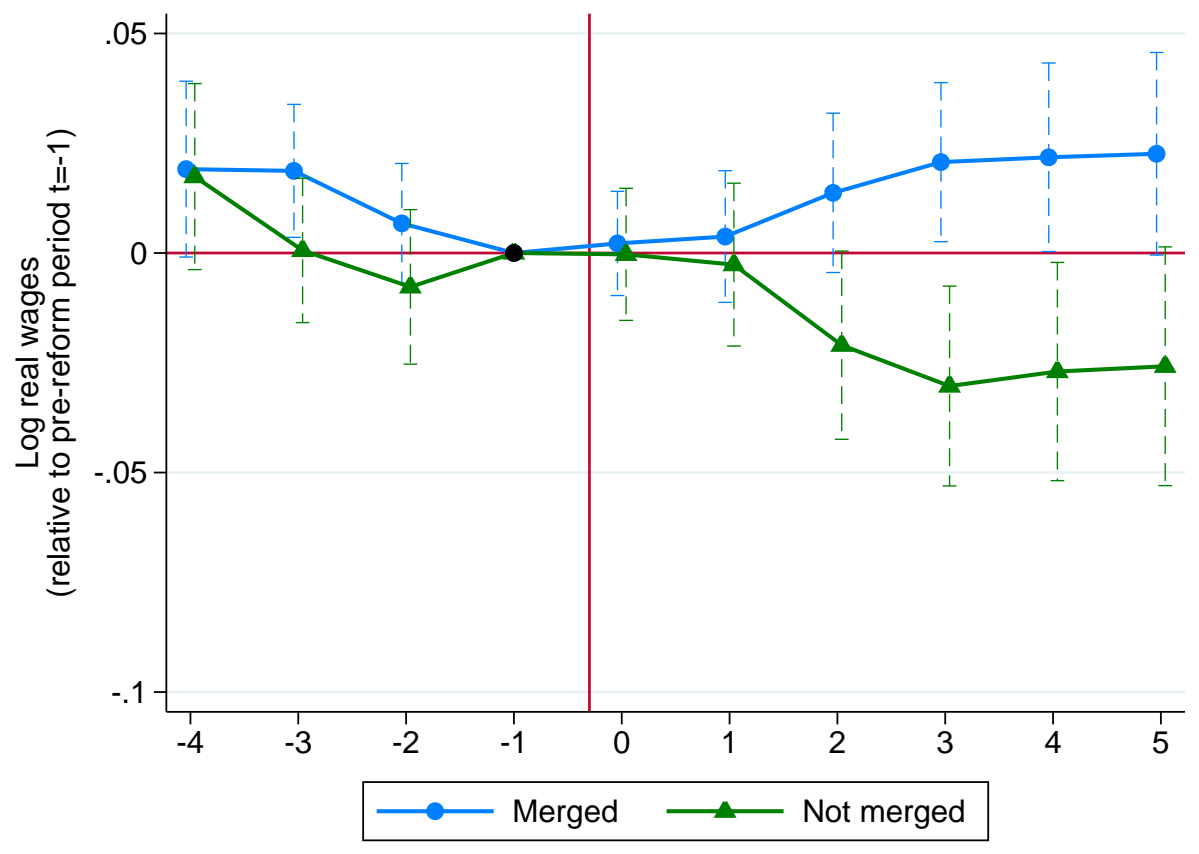

Source: LIAB and Statistical Offices of the Länder. Notes: All curves depict event study estimates $\left(\gamma_{j}, j \in[-4,5]\right)$ and the corresponding $95 \%$ confidence bands obtained by estimating equation (2) on the municipal level. The graph shows the evolution of wages in log points $\left(100 \cdot \gamma_{j}\right)$ before and after a change of the LBT rate. A value of -0.05 implies a wage elasticity with respect to LBT rates of -0.17 (see Section 5.5). The tax reform occurred for the treatment group on 1 January in event year $t=0$, as indicated by the vertical red line. Wages are observed on 30 June for each year. The estimation sample includes all establishments in non-merged and merged municipalities (see legend). All regression models include "state $\times$ year" fixed effects and the following local control variables: log municipal revenues, log municipal population, log county unemployment rate, log county GDP (all lagged by two periods). Standard errors are clustered at the municipal level. 
Figure D.2: Effects on firm wages - results across the wage distribution

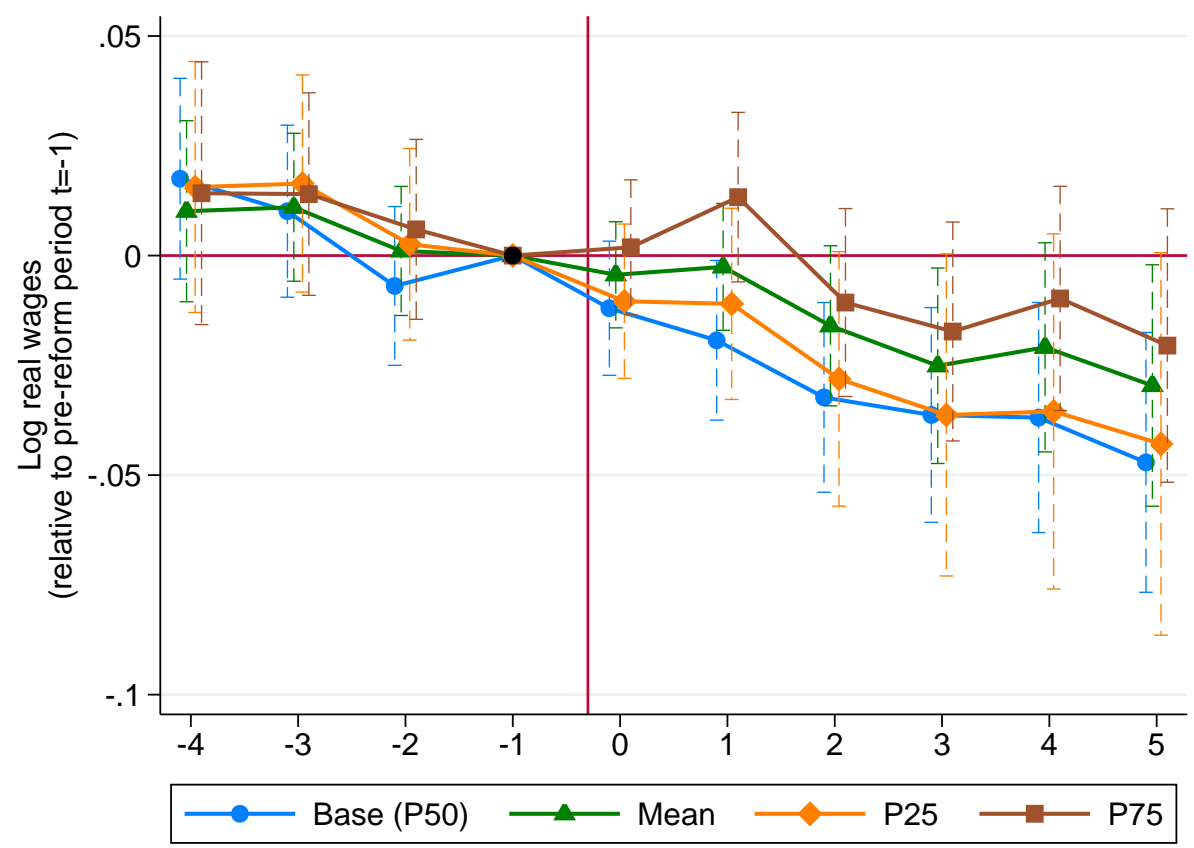

Source: LIAB and Statistical Offices of the Länder. Notes: All curves depict event study estimates $\left(\gamma_{j}, j \in[-4,5]\right)$ and the corresponding $95 \%$ confidence bands obtained by estimating equation (2) on the municipal level. The graph shows the evolution of wages in $\log$ points $\left(100 \cdot \gamma_{j}\right)$ before and after a change of the LBT rate. A value of -0.05 implies a wage elasticity with respect to LBT rates of -0.17 (see Section 5.5). The tax reform occurred for the treatment group on 1 January in event year $t=0$, as indicated by the vertical red line. Wages are observed on 30 June for each year. The estimation sample includes all liable establishments in non-merged municipalities. The left-hand side variables variables differ between specifications (see legend) Standard errors are clustered at the municipal level. 
Figure D.3: Effect on municipal wages

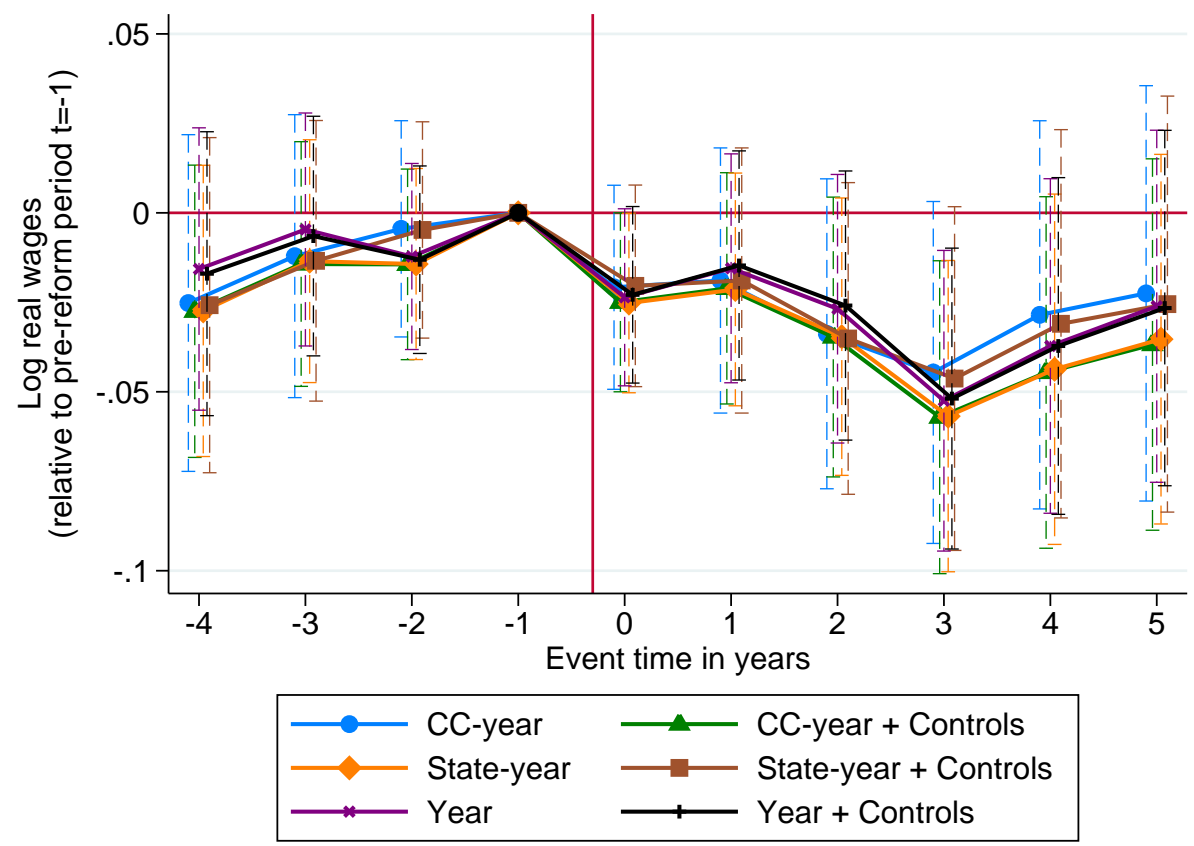

Source: LIAB and Statistical Offices of the Länder. Notes: All curves depict event study estimates $\left(\gamma_{j}, j \in[-4,5]\right)$ and the corresponding $95 \%$ confidence bands obtained by estimating equation $(2)$ on the municipal level. The graph shows the evolution of wages in $\log$ points $\left(100 \cdot \gamma_{j}\right)$ before and after a change of the LBT rate. A value of -0.05 implies a wage elasticity with respect to LBT rates of -0.17 (see Section 5.5). The tax reform occurred for the treatment group on 1 January in event year $t=0$, as indicated by the vertical red line. Wages are observed on 30 June for each year. The estimation sample includes non-merged municipalities. Depending on the specification, regression models include year, "state time year" or "commuting zone times year" fixed effects and/or municipal controls (log municipal revenues, log municipal population, log county unemployment rate, log county GDP, all lagged by two periods), see legend. Standard errors are clustered at the municipal level. 
Figure D.4: Event study: Individual level sensitivity tests

Panel A: Liable vs. non-liable

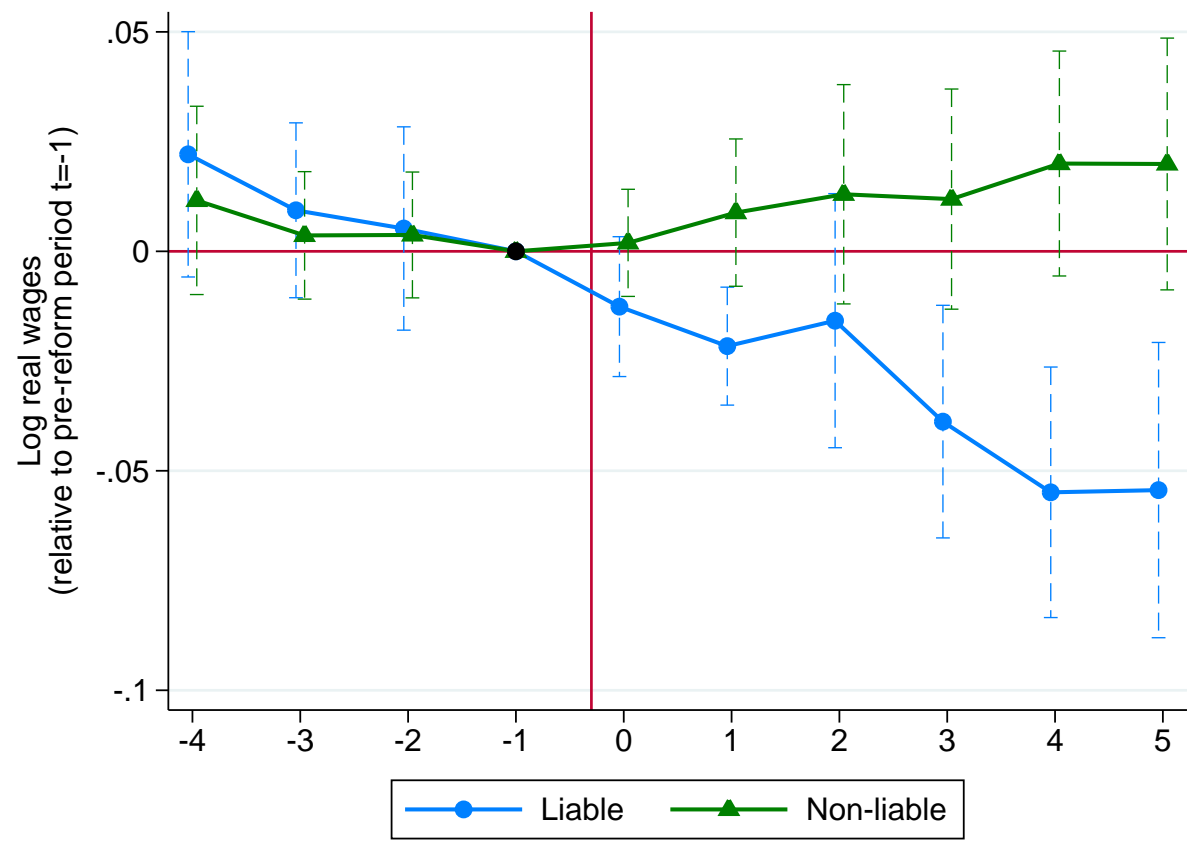

Panel B: Robustness with respect to controls

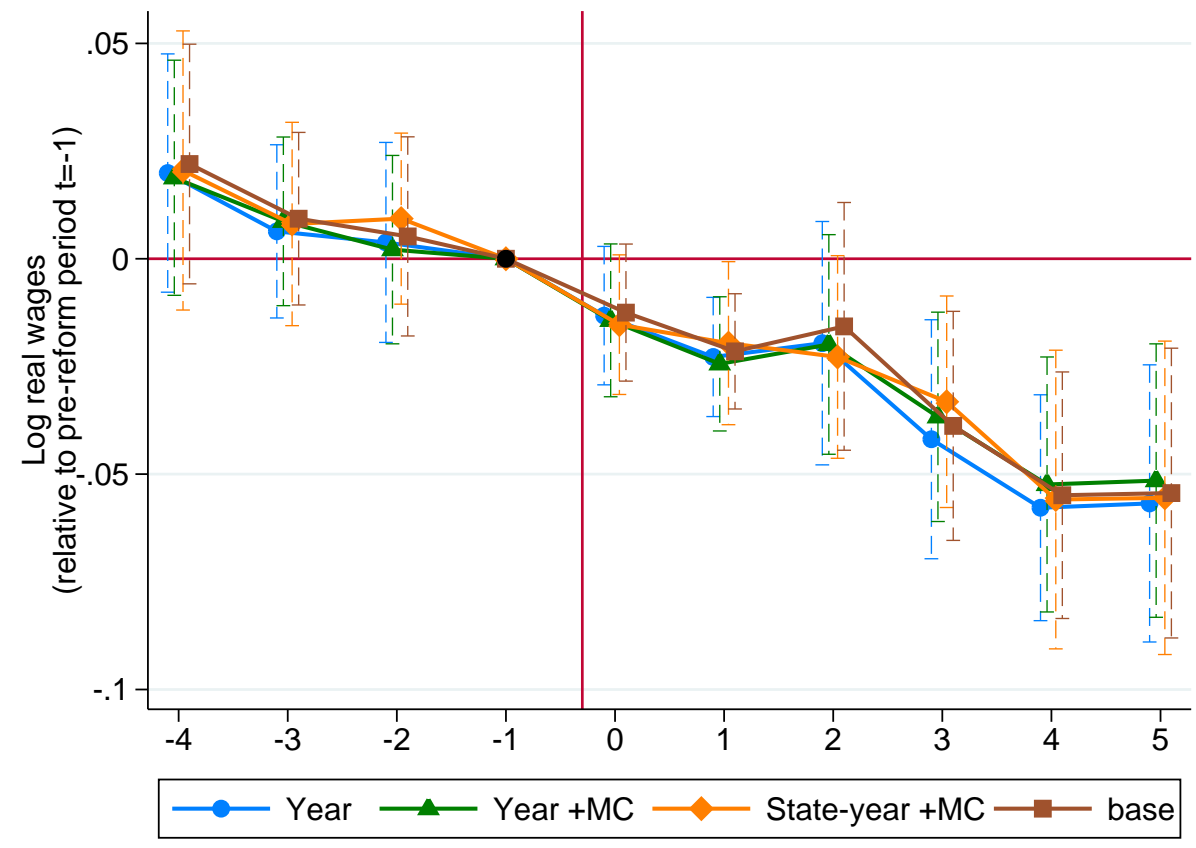

Source: LIAB and Statistical Offices of the Länder. Notes: All curves depict event study estimates $\left(\gamma_{j}, j \in[-4,5]\right)$ and the corresponding $95 \%$ confidence bands obtained by estimating equation (3). The graph shows the evolution of wages in $\log$ points $\left(100 \cdot \gamma_{j}\right)$ before and after a change of the LBT rate. A value of -0.05 implies a wage elasticity with respect to LBT rates of -0.17 (see Section 5.5). The tax reform occurred for the treatment group on 1 January in event year $t=0$, as indicated by the vertical red line. Wages are observed on 30 June for each year. The estimation sample includes all establishments in non-merged municipalities in Panel A and liable establishments in non-merged municipalities in Panel B. Panel A looks separately at workers in liable and non-liable establishment (see legend). In Panel A, all regression models include "state $\times$ year" fixed effects and the following local control variables: $\log$ municipal revenues, log municipal population, log county unemployment rate, log county GDP (all lagged by two periods). In Panel B, the included control variables vary depending on the specification (see legend). Standard errors are clustered at the municipal level. 
Figure D.5: Effects on local unemployment

Panel A: Effects on municipal unemployment p.c.

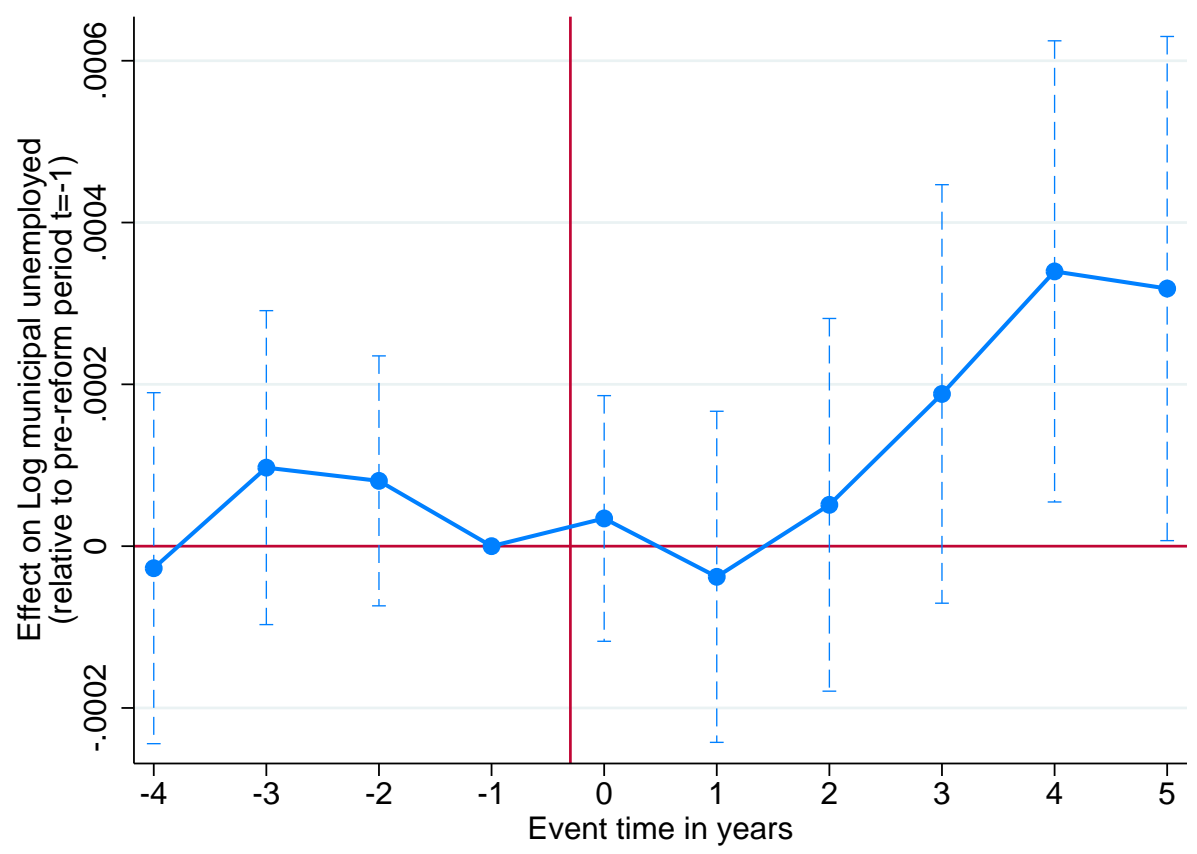

Panel B: Effects on county-level unemployment rate

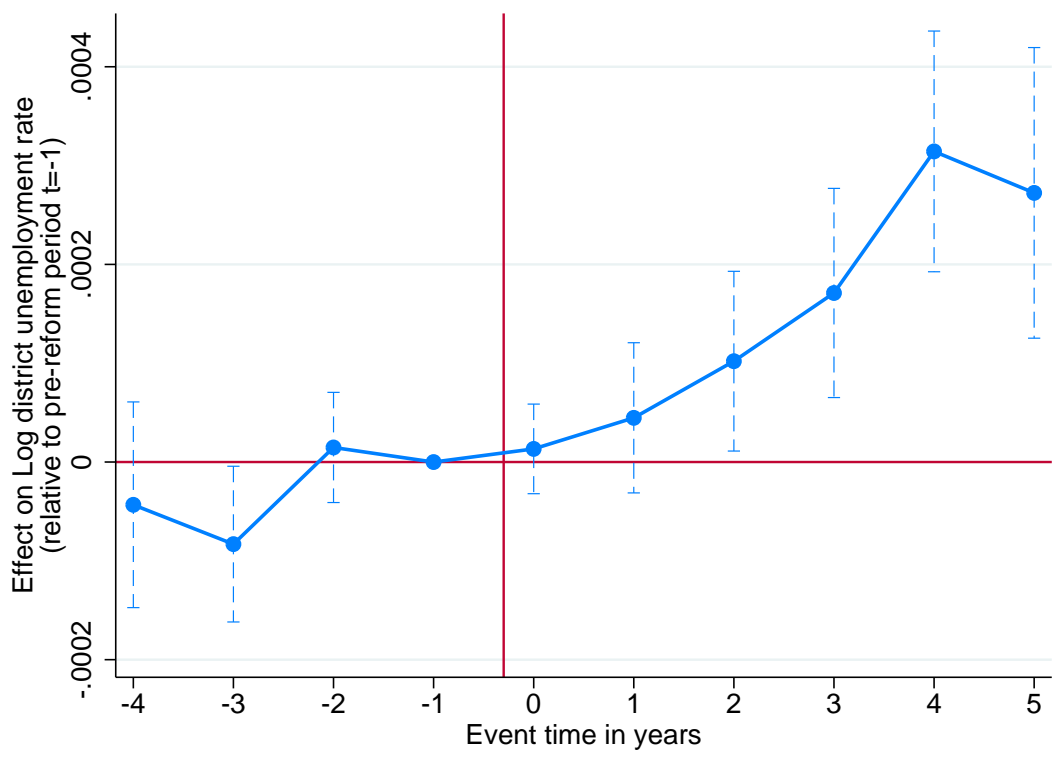

Source: Statistical Offices of the Länder. Notes: All curves depict event study estimates $\left(\gamma_{j}, j \in[-4,5]\right)$ and the corresponding $95 \%$ confidence bands obtained by estimating equation (2) on the municipal level. In Panel A, the left-hand-side variable of the regression is the log number of unemployed per capita in municipality $m$ and year $t$. In Panel $\mathrm{B}$, the left-hand-side variable is the unemployment rate in county $c$ and year $t$. The graph shows the evolution of the dependent variable before and after a reform of the LBT. The tax reform occurred for the treatment group on 1 January in event year $t=0$, as indicated by the vertical red line. The estimation sample includes all non-merged municipalities. All regression models include "state $\times$ year" fixed effects and the following local control variables: log municipal revenues, log municipal population, log county unemployment rate, log county GDP (all lagged by two periods). Standard errors are clustered at the municipal level. 
Figure D.6: Effects on GDP and fiscal surplus

Panel A: Effects on county-level GDP

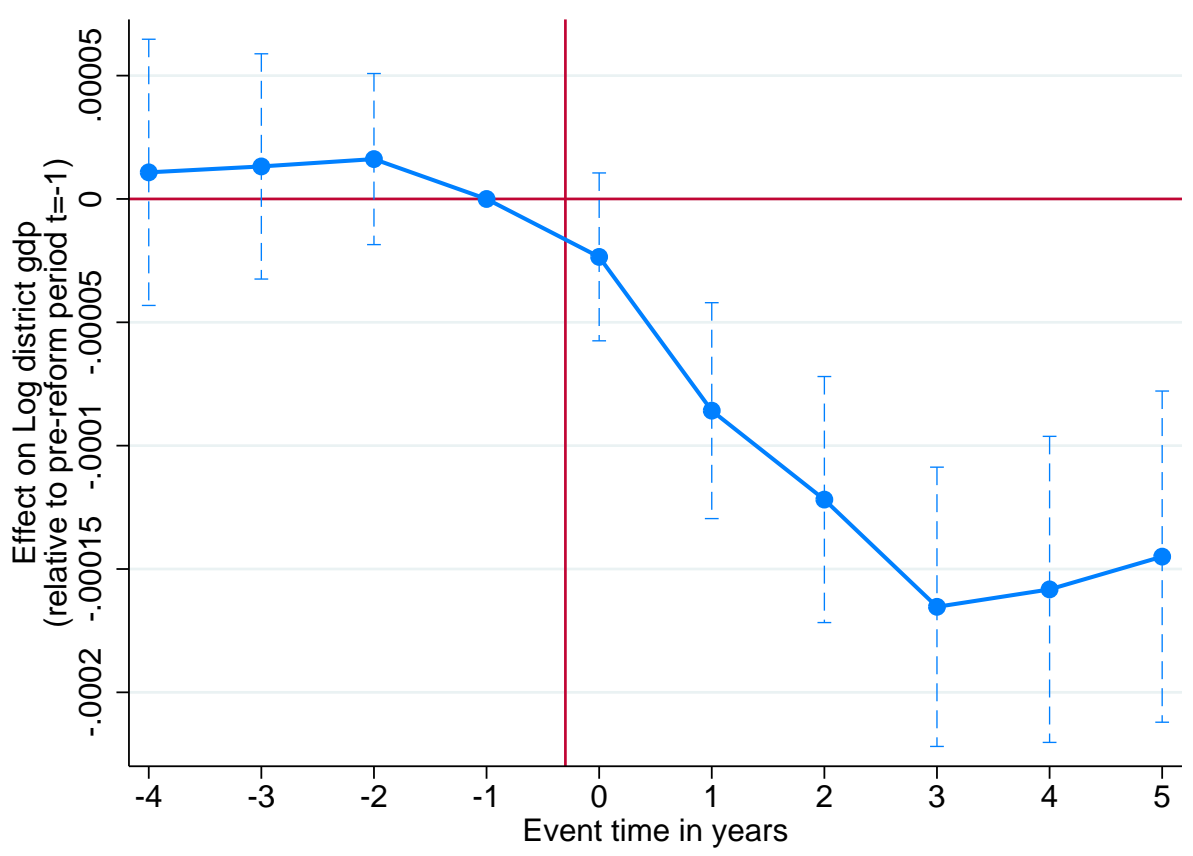

Panel B: Effects on municipal fiscal surplus

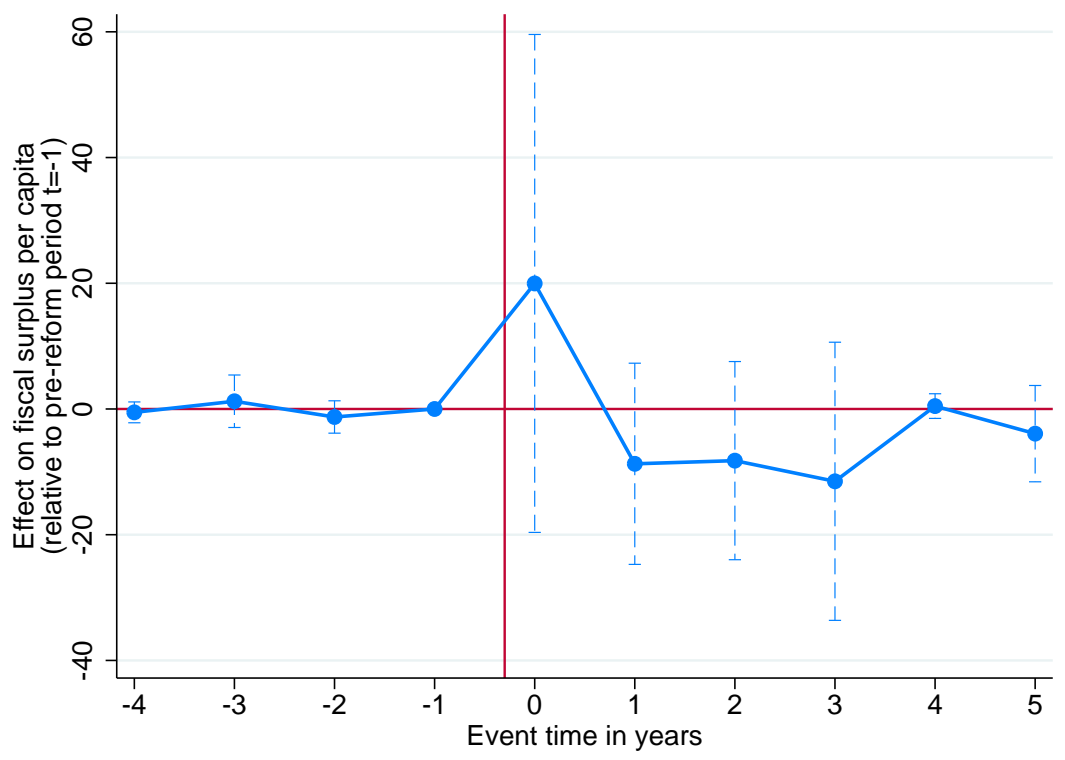

Source: Statistical Offices of the Länder. Notes: All curves depict event study estimates $\left(\gamma_{j}, j \in[-4,5]\right)$ and the corresponding $95 \%$ confidence bands obtained by estimating equation (2) on the municipal level. The left-hand-side variable of the regression is $\log$ GDP per capita in county $c$ and year $t$. The graph shows the evolution of the dependent variable before and after a reform of the LBT. The tax reform occurred for the treatment group on 1 January in event year $\mathrm{t}=0$, as indicated by the vertical red line. The estimation sample includes all non-merged municipalities. All regression models include "state $\times$ year" fixed effects and the following local control variables: $\log$ municipal revenues, $\log$ municipal population, log county unemployment rate, log county GDP (all lagged by two periods). Standard errors are clustered at the municipal level. 


\section{E Regression tables}

Table E.7: Effect on firm wages - baseline estimate

\begin{tabular}{|c|c|c|c|c|c|c|}
\hline Sample & $\begin{array}{c}(1) \\
\text { non-liable }\end{array}$ & $\begin{array}{c}(2) \\
\text { liable }\end{array}$ & $\begin{array}{c}(3) \\
\text { liable }\end{array}$ & $\begin{array}{c}(4) \\
\text { liable }\end{array}$ & $\begin{array}{c}(5) \\
\text { liable }\end{array}$ & $\begin{array}{c}(6) \\
\text { liable }\end{array}$ \\
\hline \multirow[t]{2}{*}{-4} & 0.00026 & 0.00018 & 0.00016 & 0.00018 & 0.00009 & 0.00011 \\
\hline & $(0.00017)$ & $(0.00012)$ & $(0.00011)$ & $(0.00013)$ & $(0.00011)$ & $(0.00018)$ \\
\hline \multirow[t]{2}{*}{-3} & 0.00012 & 0.00010 & 0.00006 & 0.00014 & 0.00002 & 0.00009 \\
\hline & $(0.00013)$ & $(0.00010)$ & $(0.00009)$ & $(0.00011)$ & $(0.00009)$ & $(0.00016)$ \\
\hline \multirow[t]{2}{*}{-2} & 0.00008 & -0.00007 & -0.00009 & -0.00004 & -0.00010 & -0.00004 \\
\hline & $(0.00011)$ & $(0.00009)$ & $(0.00009)$ & $(0.00010)$ & $(0.00008)$ & $(0.00012)$ \\
\hline \multirow[t]{2}{*}{0} & $0.00021^{* *}$ & -0.00012 & -0.00012 & -0.00007 & -0.00007 & -0.00017 \\
\hline & $(0.00009)$ & $(0.00008)$ & $(0.00007)$ & $(0.00009)$ & $(0.00007)$ & $(0.00011)$ \\
\hline \multirow[t]{2}{*}{1} & $0.00033^{* * *}$ & ${ }^{*}-0.00019^{* *}$ & $-0.00016^{*}$ & $-0.00022^{* *}$ & -0.00011 & -0.00009 \\
\hline & $(0.00011)$ & $(0.00009)$ & $(0.00009)$ & $(0.00011)$ & $(0.00009)$ & $(0.00015)$ \\
\hline \multirow[t]{2}{*}{2} & 0.00017 & $-0.00032^{* *}$ & $* *_{-} 0.00032 * *$ & $k *-0.00026^{* *}$ & $-0.00026^{* *}$ & **-0.00016 \\
\hline & $(0.00013)$ & $(0.00011)$ & $(0.00011)$ & $(0.00012)$ & $(0.00010)$ & $(0.00018)$ \\
\hline \multirow[t]{2}{*}{3} & 0.00015 & $-0.00036^{* *}$ & $* *_{-} 0.00030 * *$ & $-0.00034^{* *}$ & $*-0.00030 * *$ & $* *_{-0} 0.00018$ \\
\hline & $(0.00014)$ & $(0.00012)$ & $(0.00012)$ & $(0.00013)$ & $(0.00011)$ & $(0.00019)$ \\
\hline \multirow[t]{2}{*}{4} & 0.00008 & $-0.00037^{* *}$ & $* *_{-} 0.00031 * *$ & ${ }^{k}-0.00033^{* *}$ & $-0.00026^{* *}$ & $-0.00034^{*}$ \\
\hline & $(0.00016)$ & $(0.00013)$ & $(0.00013)$ & $(0.00014)$ & $(0.00012)$ & $(0.00020)$ \\
\hline \multirow[t]{2}{*}{5} & $0.00032^{*}$ & $-0.00047^{* *}$ & $<*-0.00043^{* *}$ & $k *-0.00051^{* *}$ & $*-0.00033^{* *}$ & -0.00028 \\
\hline & $(0.00019)$ & $(0.00015)$ & $(0.00014)$ & $(0.00015)$ & $(0.00013)$ & $(0.00022)$ \\
\hline Municipal controls & yes & yes & & yes & & yes \\
\hline Firm controls & & & & & & yes \\
\hline Year FE & & & & & yes & \\
\hline State $\mathrm{x}$ year FE & yes & yes & yes & & & \\
\hline Commuting zone $\mathrm{x}$ year FE & & & & yes & & yes \\
\hline $\mathrm{N}$ & 20287 & 36090 & 38676 & 36090 & 38676 & 13660 \\
\hline Firms & 5501 & 10920 & 11449 & 10920 & 11449 & 4582 \\
\hline
\end{tabular}

Source: LIAB. Notes: This table shows the regression estimates depicted in Figures 2 and 3 - see these figures for the exact specification. The models are estimated on different firms types (as indicated by the table head) in non-merged municipalities. Columns (1) and (2) show the results from Figure 2 for non-liable and liable firms, respectively. Column (2) is our baseline estimate using "state $\times$ year" fixed effects (also depicted in Figure 3). Column (3) to (6) contain the results for liable firms for various sets of control variables (see bottom of the regression table). Standard errors are clustered at the municipal level. Significance levels are ${ }^{*}<0.10,{ }^{* *}<0.05,{ }^{* * *}<0.01$. 
Table E.8: Effect on firm wages - heterogeneity I

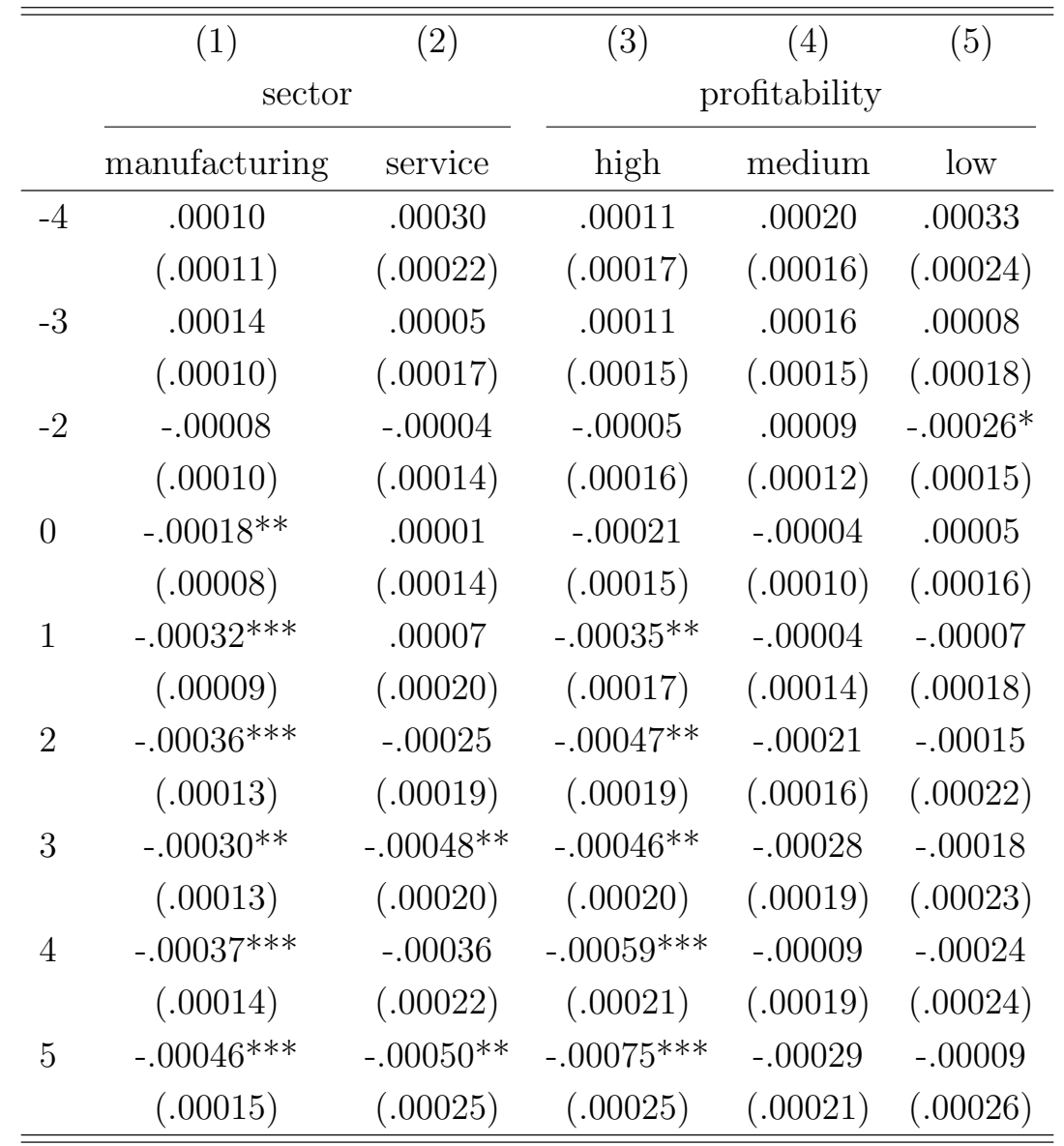

Source: LIAB. Notes: This table shows the regression estimates depicted in Figures 4 and 7 - see these figures for the exact specification. The models are estimated on the baseline sample of liable firms in non-merged municipalities. Columns (1) and (2) show the results of the interacted event study coefficients by industry (see Figure 4). Column (3) to (5) show the results of the interacted event study coefficients by profitability (see Figure 7). All regression include "state x year" fixed effects and municipal controls. Standard errors are clustered at the municipal level. Significance levels are ${ }^{*}<0.10,{ }^{* *}<0.05,{ }^{* * *}<0.01$. 
Table E.9: Effect on firm wages - heterogeneity II

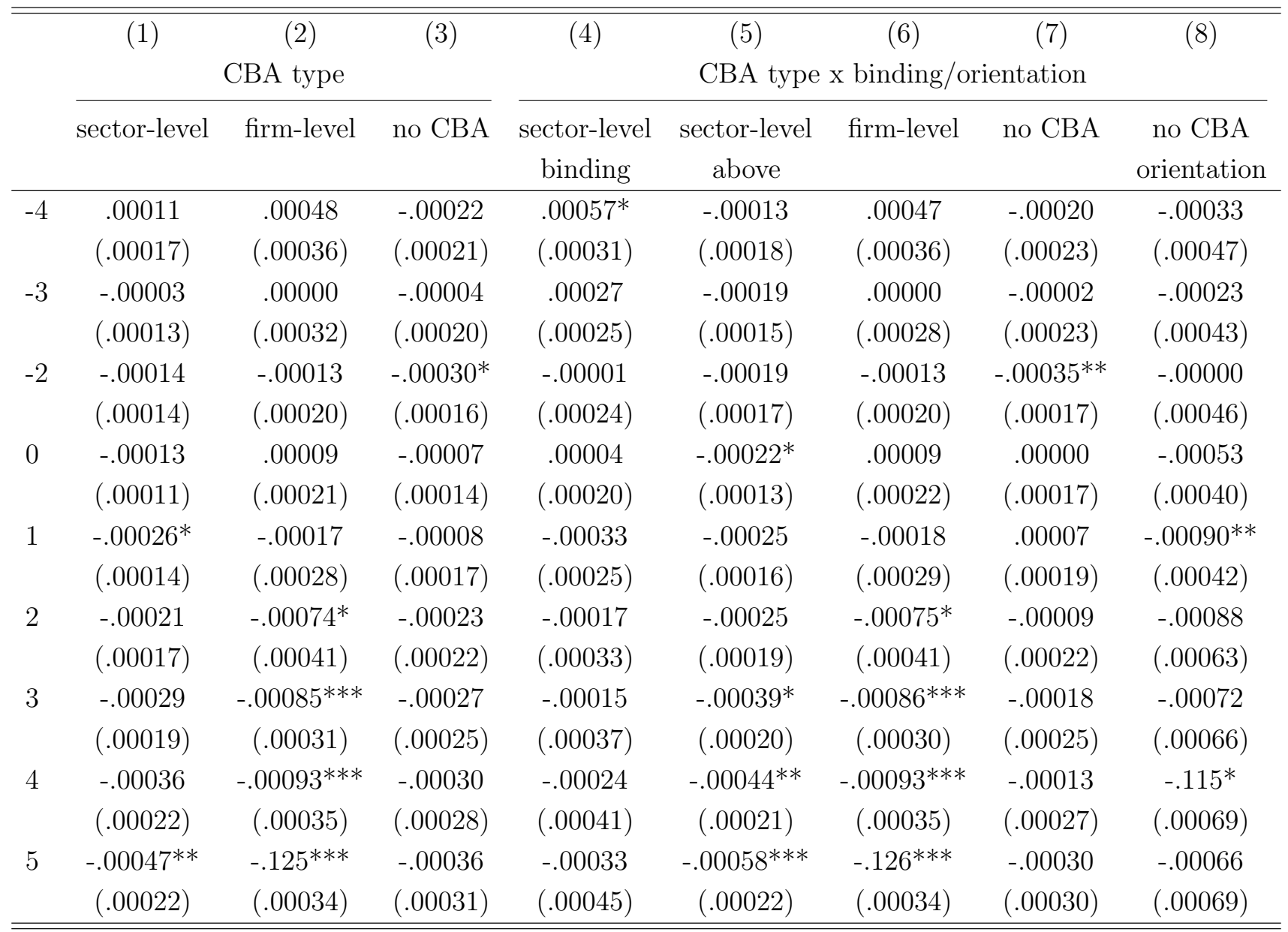

Notes: This table shows the regression estimates depicted in Figures 5, Panels A and B - see figure for the exact specification. The models are estimated on the baseline sample of liable firms in non-merged municipalities. Columns (1) to (3) show the results of the interacted event study coefficients by type of collective bargaining agreement (see Panel A of Figure 4). Column (4) to (8) show the results of the interacted event study coefficients by type of CBA, broken down whether agreements are binding or not and whether no CBA firms take sector level CBAs as a reference points (see Panel B of Figure 4). All regression include "state x year" fixed effects and municipal controls. Standard errors are clustered at the municipal level. Significance levels are ${ }^{*}<0.10,{ }^{* *}<0.05,{ }^{* * *}<0.01$. 
Table E.10: Effect on firm wages - heterogeneity III

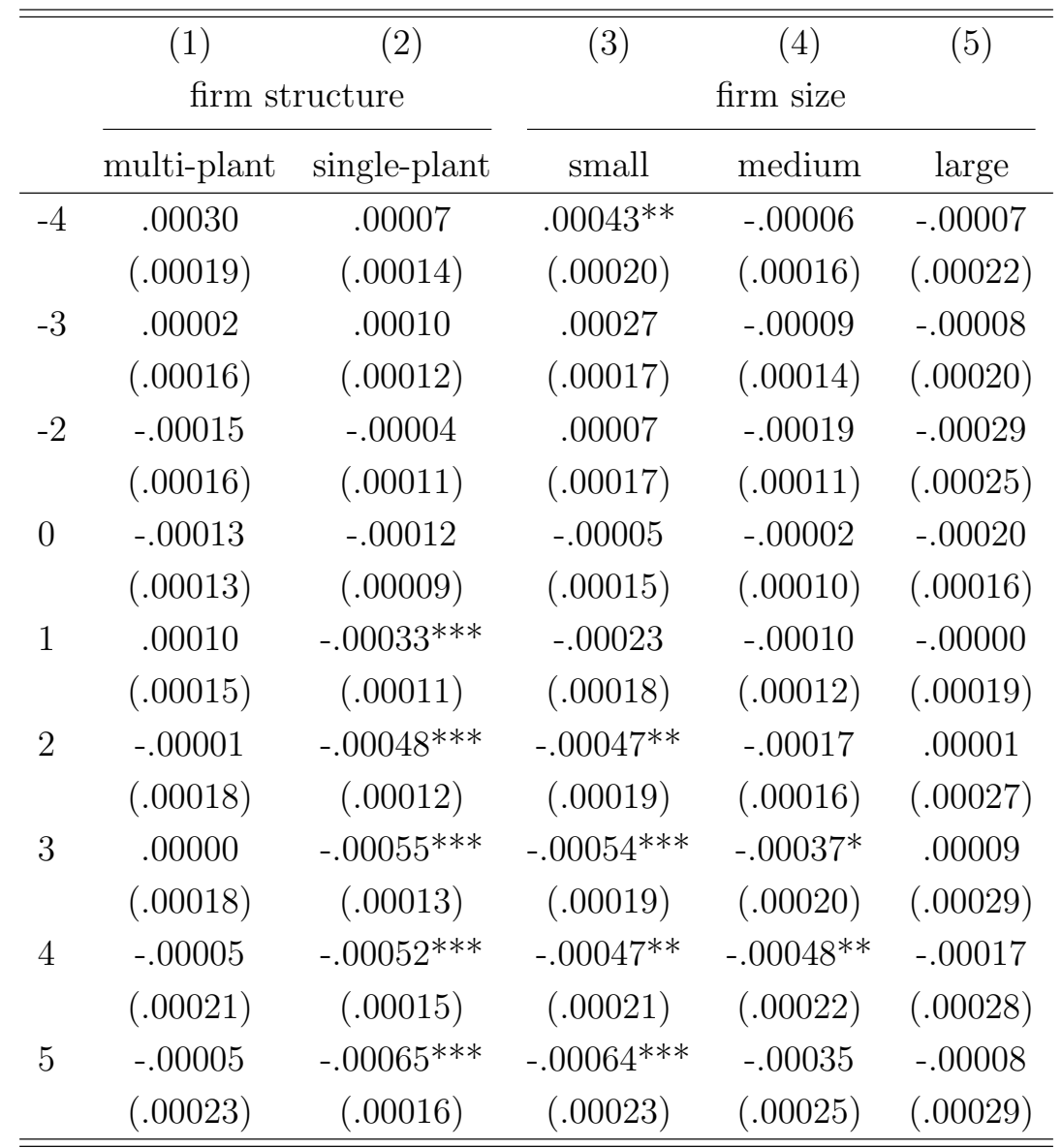

Source: LIAB. Notes: This table shows the regression estimates depicted in Figures 6, Panels A and B see figure for the exact specification. The models are estimated on the baseline sample of liable firms in non-merged municipalities. Columns (1) and (2) show the results of the interacted event study coefficients by firm structure (see Panel A of Figure 6). Column (3) to (5) show the results of the interacted event study coefficients by firm size (see Panel B of Figure 6). All regression include "state x year" fixed effects and municipal controls. Standard errors are clustered at the municipal level. Significance levels are * $<0.10,{ }^{* *}<0.05,{ }^{* * *}<0.01$. 
Table E.11: Effect on individual wages - heterogeneity I

\begin{tabular}{|c|c|c|c|c|c|c|c|}
\hline \multirow[t]{3}{*}{ 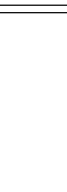 } & (1) & (2) & \multirow[t]{2}{*}{ (3) } & (4) & (5) & (6) & (7) \\
\hline & & skill & & \multicolumn{2}{|c|}{ collar type } & \multicolumn{2}{|c|}{ gender } \\
\hline & high & medium & low & blue & white & female & male \\
\hline \multirow[t]{2}{*}{-4} & .00005 & .00006 & .00035 & .00010 & .00008 & $.00033^{* *}$ & .00010 \\
\hline & $(.00012)$ & $(.00014)$ & $(.00023)$ & $(.00017)$ & $(.00016)$ & $(.00016)$ & $(.00015)$ \\
\hline \multirow[t]{2}{*}{-3} & .00013 & -.00002 & .00016 & -.00001 & .00007 & .00013 & .00003 \\
\hline & $(.00011)$ & $(.00011)$ & $(.00013)$ & $(.00013)$ & $(.00009)$ & $(.00012)$ & $(.00011)$ \\
\hline \multirow[t]{2}{*}{-2} & .00009 & -.00001 & .00011 & -.00001 & .00008 & -.00003 & .00004 \\
\hline & $(.00011)$ & $(.00012)$ & $(.00014)$ & $(.00013)$ & $(.00009)$ & $(.00015)$ & $(.00012)$ \\
\hline \multirow[t]{2}{*}{0} & $.00012^{*}$ & -.00010 & -.00020 & -.00012 & -.00006 & $-.00018^{* *}$ & -.00009 \\
\hline & $(.00006)$ & $(.00008)$ & $(.00013)$ & $(.00009)$ & $(.00006)$ & $(.00008)$ & $(.00008)$ \\
\hline \multirow[t]{2}{*}{1} & .00010 & $-.00021^{* * *}$ & $-.00029^{* *}$ & $-.00019^{* *}$ & $-.00022^{* *}$ & $-.00038^{* * *}$ & $-.00019^{* *}$ \\
\hline & $(.00007)$ & $(.00007)$ & $(.00012)$ & $(.00009)$ & $(.00010)$ & $(.00010)$ & $(.00008)$ \\
\hline \multirow[t]{2}{*}{2} & .00013 & -.00004 & -.00011 & -.00003 & -.00008 & $-.00038^{* *}$ & -.00000 \\
\hline & $(.00011)$ & $(.00016)$ & $(.00014)$ & $(.00016)$ & $(.00009)$ & $(.00016)$ & $(.00013)$ \\
\hline \multirow[t]{2}{*}{3} & .00012 & $-.00039^{* * *}$ & -.00030 & $-.00040^{* *}$ & $-.00025^{* * *}$ & $-.00068^{* * *}$ & $-.00032^{* *}$ \\
\hline & $(.00011)$ & $(.00014)$ & $(.00021)$ & $(.00017)$ & $(.00009)$ & $(.00015)$ & $(.00014)$ \\
\hline \multirow[t]{2}{*}{4} & .00007 & $-.00058^{* * *}$ & $-.00054^{* * *}$ & $-.00062^{* * *}$ & $-.00035^{* * *}$ & $-.00090^{* * *}$ & $-.00050^{* * *}$ \\
\hline & $(.00012)$ & $(.00014)$ & $(.00016)$ & $(.00016)$ & $(.00011)$ & $(.00017)$ & $(.00016)$ \\
\hline \multirow[t]{2}{*}{5} & .00015 & $-.00061^{* * *}$ & $-.00047^{*}$ & $-.00068^{* * *}$ & $-.00031^{* *}$ & $-.00097^{* * *}$ & $-.00049^{* * *}$ \\
\hline & $(.00013)$ & $(.00017)$ & $(.00025)$ & $(.00020)$ & $(.00013)$ & $(.00021)$ & $(.00016)$ \\
\hline
\end{tabular}

Source: LIAB. Notes: This table shows the regression estimates depicted in Figures 8, Panels A and B, as well as Figure 9 - see figure for the exact specification. The models are estimated on workers in liable firms in non-merged municipalities. Columns (1) to (3) show the results of the interacted event study coefficients by skill (see Panel A of Figure 8). Columns (4) and (5) show the results of the interacted event study coefficients by collar type (see Panel B of Figure 8). Columns (6) and (7) show the results of the interacted event study coefficients by gender (see Figure 9). All regression include "state x year" fixed effects and municipal controls. Standard errors are clustered at the municipal level. Significance levels are ${ }^{*}<0.10,{ }^{* *}<0.05,{ }^{* * *}<0.01$. 